


\section{Populatie-genetische nulmeting heikikker in de Vechtstreek (Noord-Holland)}

En advies voor een studie naar de effecten van aangelegde faunapassages voor heikikker en ringslang

E.A. van der Grift, F.G.W.A. Ottburg, D.R. Lammertsma, I. Laros en G.A. de Groot

Dit onderzoek is uitgevoerd door Wageningen Environmental Research in opdracht van en gefinancierd door de provincie Noord-Holland.

Wageningen Environmental Research

Wageningen, september 2021

Gereviewd door:

A.G.M. Schotman, onderzoeker Dierecologie (Wageningen Environmental Research)

Akkoord voor publicatie:

M. Kluivers-Poodt, teamleider Dierecologie

Rapport 3115

ISSN 1566-7197 
Van der Grift, E.A., G.A. de Groot, F.G.W.A. Ottburg, D.R. Lammertsma, I. Laros, 2021. Populatiegenetische nulmeting heikikker in de Vechtstreek (Noord-Holland); En advies voor een studie naar de effecten van aangelegde faunapassages voor heikikker en ringslang. Wageningen, Wageningen Environmental Research, Rapport 3115. 50 blz.; 21 fig.; 3 tab.; 48 ref.

In opdracht van de provincie Noord-Holland is een nulmeting uitgevoerd van de huidige genetische kenmerken van heikikkers (Rana arvalis) in de Vechtstreek. Op basis hiervan is een advies opgesteld voor een effectmeting, waarmee het functioneren van in de regio aangelegde faunapassages voor de heikikker kan worden geëvalueerd. Tevens is de haalbaarheid van een vergelijkbare studie naar de ringslang (Natrix helvetica) verkend en is een advies voor een effectstudie opgesteld, waarmee het functioneren van aangelegde faunapassages voor de ringslang kan worden geëvalueerd.

A baseline measurement of the current genetic characteristics of moor frogs (Rana arvalis) in the Vecht region was carried out on behalf of the province of Noord-Holland. Based on this, a recommendation has been drawn up for an effect measurement, which can be used to evaluate the functioning of fauna passages for the moor frog in the region. The feasibility of a comparable study on grass snakes (Natrix helvetica) has also been explored and advice has been drawn up for an effect study, which can be used to evaluate the functioning of constructed fauna passages for grass snakes.

Trefwoorden: versnippering, ontsnippering, barrièrewerking, mitigatie, faunapassage, verkeersweg, spoorweg, Naardermeer, heikikker, Rana arvalis, ringslang, Natrix helvetica, DNA, genetica

Dit rapport is gratis te downloaden van https://doi.org/10.18174/554131 of op www.wur.nl/environmental-research (ga naar 'Wageningen Environmental Research' in de grijze balk onderaan). Wageningen Environmental Research verstrekt geen gedrukte exemplaren van rapporten.

2021 Wageningen Environmental Research (instituut binnen de rechtspersoon Stichting Wageningen Research), Postbus 47, 6700 AA Wageningen, T 03174807 00, www.wur.nl/environmental-research. Wageningen Environmental Research is onderdeel van Wageningen University \& Research.

- Overname, verveelvoudiging of openbaarmaking van deze uitgave is toegestaan mits met duidelijke bronvermelding.

- Overname, verveelvoudiging of openbaarmaking is niet toegestaan voor commerciële doeleinden en/of geldelijk gewin.

- Overname, verveelvoudiging of openbaarmaking is niet toegestaan voor die gedeelten van deze uitgave waarvan duidelijk is dat de auteursrechten liggen bij derden en/of zijn voorbehouden.

Wageningen Environmental Research aanvaardt geen aansprakelijkheid voor eventuele schade voortvloeiend uit het gebruik van de resultaten van dit onderzoek of de toepassing van de adviezen.

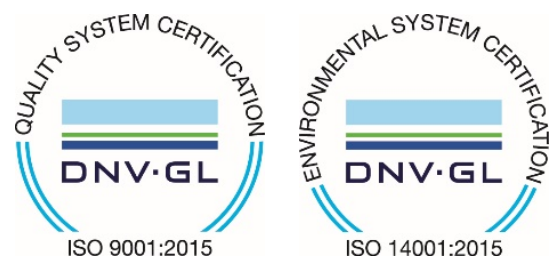

Wageningen Environmental Research werkt sinds 2003 met een ISO 9001 gecertificeerd kwaliteitsmanagementsysteem. In 2006 heeft Wageningen Environmental Research een milieuzorgsysteem geïmplementeerd, gecertificeerd volgens de norm ISO 14001.

Wageningen Environmental Research geeft via ISO 26000 invulling aan haar maatschappelijke verantwoordelijkheid.

Wageningen Environmental Research Rapport 3115 | ISSN 1566-7197

Foto omslag: Volwassen heikikker (Rana arvalis), man. (c) Fabrice Ottburg 


\section{Inhoud}

$\begin{array}{lr}\text { Verantwoording } & \mathbf{5}\end{array}$

$\begin{array}{lr}\text { Woord vooraf } & 7\end{array}$

$\begin{array}{lr}\text { Samenvatting } & 9\end{array}$

$1 \quad$ Inleiding $r$

1.1 Achtergrond $\quad 12$

1.2 Heikikker in de Vechtstreek $\quad 15$

$\begin{array}{ll}1.3 & \text { Ringslang in de Vechtstreek } \\ 1.4\end{array}$

1.4 Potentiële meerwaarde populatie-genetisch onderzoek 19

1.5 Doel van het onderzoek 19

$\begin{array}{ll}1.6 & \text { Onderzoeksvragen }\end{array}$

$\begin{array}{ll}1.7 & \text { Aanpak van het onderzoek }\end{array}$

$\begin{array}{lll}1.8 & \text { Leeswijzer } & 20\end{array}$

$2 \quad$ Review literatuur heikikker $r$

$\begin{array}{lll}2.1 & \text { Inleiding } & 21\end{array}$

$\begin{array}{lll}2.2 & \text { Werkwijze } & 21\end{array}$

$\begin{array}{lll}2.3 & \text { Bevindingen } & 21\end{array}$

2.3.1 Genetische variatie in heikikkerpopulaties 21

2.3.2 Genetische verschillen tussen heikikkerpopulaties 22

$\begin{array}{lll}2.4 & \text { Conclusies } & 23\end{array}$

$3 \quad$ Populatie-genetisch onderzoek heikikker $\quad 24$

$\begin{array}{lll}3.1 & \text { Inleiding } & 24\end{array}$

$\begin{array}{lll}3.2 & \text { Studiegebied } & 24\end{array}$

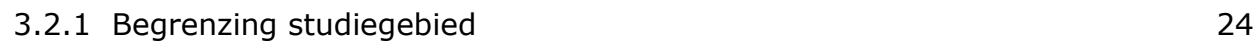

$\begin{array}{ll}3.2 .2 \text { Beschrijving studiegebied } & 25\end{array}$

$\begin{array}{lll}3.3 & \text { Methode } & 27\end{array}$

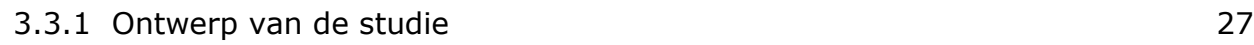

3.3.2 Monsterlocaties in het studiegebied $\quad 28$

$\begin{array}{ll}3.3 .3 \text { Referentiegebieden } & 29\end{array}$

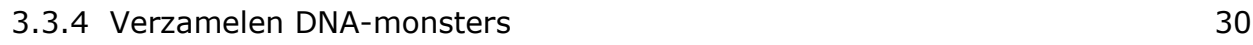

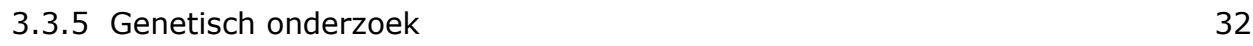

3.3.6 Data-analyse $\quad 34$

$\begin{array}{lll}3.4 & \text { Resultaten } & 35\end{array}$

3.4.1 Genetische variatie $\quad 35$

3.4.2 Genetische verschillen tussen (deel)populaties $\quad 35$

$\begin{array}{lll}3.5 & \text { Conclusies } & 39\end{array}$

$\begin{array}{llr}4 & \text { Advies effectstudie heikikker } & 40\end{array}$

$\begin{array}{lll}4.1 & \text { Inleiding } & 40\end{array}$

4.2 Haalbaarheid effectstudie faunapassages 40

$\begin{array}{lll}4.3 & \text { Advies } & 40\end{array}$

4.3.1 Effectstudie faunapassages N236 40

4.3.2 Effectstudie faunapassage spoorlijn Weesp-Almere $\quad 41$ 
$\begin{array}{lll}5.1 & \text { Inleiding } & 42\end{array}$

5.2 Werkwijze $\quad 42$

5.3 Geschiktheid van ringslang als onderzoeksoort $\quad 42$

5.4 Advies populatie-genetisch onderzoek ringslang 44

$\begin{array}{lr}\text { Literatuur } & 45\end{array}$

Populatie-genetische begrippenlijst 


\section{Verantwoording}

Rapport: 3115

Projectnummer: 5200045320

Wageningen Environmental Research (WENR) hecht grote waarde aan de kwaliteit van zijn eindproducten. Een review van de rapporten op wetenschappelijke kwaliteit door een referent maakt standaard onderdeel uit van ons kwaliteitsbeleid.

Akkoord Referent die het rapport heeft beoordeeld,

functie: Onderzoeker Dierecologie

naam: A.G.M. Schotman

datum: $17-82021$

Akkoord teamleider voor de inhoud,

naam: M. Kluivers-Poodt

datum: $\quad 20-82021$ 


\section{Woord vooraf}

Waarom zou de provincie Noord-Holland in hemelsnaam geïnteresseerd zijn in eiklompjes van heikikkers? "Hebben ze daar niks beters te doen?" Op het eerste gezicht lijkt het inderdaad vreemd dat een provincie zulk specialistisch onderzoek laat doen. Maar wie even verder kijkt, ziet dat de provincie sinds kort verantwoordelijk is voor de uitvoering van het gehele natuurbeleid. Inclusief monitoring en verantwoording. De ruggengraat van het natuurbeleid is het natuurnetwerk (NNN). In de natuurgebieden wordt hard gewerkt om de kwaliteit te verbeteren en de oppervlakte te vergroten. Tussen de natuurgebieden wordt ook hard gewerkt aan natuurverbindingen en het opheffen van barrières. Juist die verbindingen zijn van cruciaal belang voor de kwaliteit van het hele natuurnetwerk. Isolatie leidt immers tot inteelt in (te kleine) populaties. Uitwisseling van dieren en planten tussen de natuurgebieden is dus hard nodig. Of dat lukt, proberen we op verschillende manieren te meten door bijvoorbeeld veldwaarnemingen en met camera's en sensoren. Maar de zekerste manier gaat via de genetische samenstelling. Als de samenstelling in een groot gebied sterk overeenkomt, is er sprake van genetische uitwisseling en werken de natuurverbindingen. Bijkomend voordeel is dat genetische technieken steeds nauwkeuriger worden (en goedkoper, ook belangrijk). Daarom is het dus niet zo vreemd dat de provincie Noord-Holland de genetische samenstelling laat onderzoeken van eitjes van heikikkers.

We bedanken de onderzoekers voor hun enthousiaste inzet en deze heldere rapportage. En we kijken ernaar uit om het onderzoek in 2025 te herhalen. Dan weten we nog veel beter waar de natuurverbindingen werken en waar er nog een tandje bij moet.

Nico Jonker \& Gerlies Nap - Provincie Noord-Holland 


\section{Samenvatting}

\section{Achtergrond}

De Provincie Noord-Holland werkt aan het versterken van de ecologische samenhang tussen de diverse laagveenmoerassen in de Vechtstreek door de aanleg van natuurverbindingen. In 2013 zijn hiertoe twee 75 m brede faunapassages in de N236 gerealiseerd. In 2019 zijn nog eens negen faunapassages aangelegd in de spoorlijn Amsterdam-Hilversum die het Naardermeer doorsnijdt. De Provincie Noord-Holland is benieuwd naar het functioneren van de gerealiseerde faunapassages. Eén manier om de functionaliteit van faunapassages te onderzoeken, is het meten van uitwisseling van individuen tussen populaties aan weerszijden van de infrastructuur met behulp van genetische technieken. Voor dergelijk onderzoek is het echter van belang dat er voldoende grote genetische verschillen zijn vóór - of kort na - de aanleg van de faunapassages. In dit kader heeft de provincie aan Wageningen Environmental Research gevraagd om te verkennen of voor de heikikker (Rana arvalis) aan deze voorwaarde wordt voldaan en of genetische monitoring van deze soort inzicht kan bieden in de effectiviteit van de gerealiseerde ontsnipperende maatregelen bij de N236 en de spoorlijn door het Naardermeer. Een tweede vraag van de provincie is of de ringslang (Natrix helvetica) een geschikte soort is om de effectiviteit van de faunapassages aan te tonen middels genetisch onderzoek.

\section{Doel van het onderzoek}

Het doel van het onderzoek is drieledig:

- Het uitvoeren van een nulmeting van de huidige genetische kenmerken van heikikkers in de Vechtstreek.

- Het opstellen van een advies voor een effectmeting waarmee het functioneren van de aangelegde faunapassages voor de heikikker kan worden geëvalueerd.

- Het opstellen van een advies voor een effectstudie waarmee het functioneren van de aangelegde faunapassages voor de ringslang kan worden geëvalueerd.

\section{Onderzoeksvragen}

Om deze doelen te bereiken, richten we ons in het onderzoek op de volgende vragen:

1. Wat is er nationaal en internationaal bekend over de genetische eigenschappen van heikikkers? Zijn er verschillen tussen populaties?

2. Bestaan er verschillen in genetische eigenschappen tussen populaties heikikkers in de Vechtstreek?

3. Hoe kan, op basis van het huidige onderzoek, in de toekomst vastgesteld worden of er vermenging van genetische eigenschappen van populaties heeft plaatsgevonden ten gevolge van de aanleg van de faunavoorzieningen? En na hoeveel jaar zou dergelijk onderzoek moeten plaatsvinden?

4. In hoeverre is, gezien zijn verspreidingsvermogen, de ringslang een geschikte soort om de effectiviteit van faunapassages aan te tonen middels genetisch onderzoek? En indien dit mogelijk is, hoe dient dit onderzoek er dan uit te zien?

\section{Aanpak van het onderzoek}

Voor de beantwoording van de eerste onderzoeksvraag is een literatuuronderzoek uitgevoerd. We hebben ons hierbij primair gericht op informatie in de wetenschappelijke literatuur. Voor de beantwoording van de tweede onderzoeksvraag is populatie-genetisch onderzoek uitgevoerd, waarvoor DNA-monsters van heikikkers zijn verzameld in het Naardermeer en de direct omliggende polders en natuurgebieden. Op basis van de genetische analyses is vervolgens verkend of er verschillen in genetische kenmerken zijn tussen de verschillende populaties in het gebied. Voor de beantwoording van de derde onderzoeksvraag is - mede op basis van de literatuurstudie en het verrichte populatie-genetisch onderzoek - een plan van aanpak opgesteld voor een genetische studie naar de bijdrage van de faunavoorzieningen aan de vermenging van genetische eigenschappen in de Vechtstreek. Onze zienswijze, en uitgangspunt voor het plan van aanpak, is dat een dergelijke effectstudie dient te bestaan uit een vergelijking van de genetische verschillen op twee 
meetmomenten: een nulmeting ( $t=0$; idealiter voorafgaand aan of tenminste kort na aanleg van de faunavoorzieningen) en een effectmeting $(t=1)$ in een later stadium, i.e. enige jaren nadat de faunavoorzieningen door heikikkers in gebruik zijn genomen. Voor beantwoording van de vierde onderzoeksvraag is voor de ringslang verkend welk genetisch onderzoek is verricht naar verspreidingsvermogen en ruimtelijke genetische variatie in deze soort. Hiervoor is een beknopte literatuurscan uitgevoerd, waarin zowel de huidige verspreiding van de ringslang in de Vechtstreek als publicaties van eerder populatie-genetisch onderzoek in binnen- en buitenland zijn meegenomen. De uitkomsten hiervan zijn gebruikt als basis voor de beoordeling van de waarde en aanpak van een populatie-genetische studie naar de bijdrage van de faunavoorzieningen aan de genetische vermenging van de ringslangpopulaties in het gebied.

\section{Literatuuronderzoek heikikker}

Genetische studies van heikikkerpopulaties in Noord- en Oost-Europa indiceren dat heikikkers van nature in staat zijn om enige mate van uitwisseling in stand te houden over grote afstand, tussen populaties die soms honderden kilometers van elkaar zijn verwijderd, zolang deze populaties zich bevinden in een aaneengesloten landschap bestaande uit geschikte habitat. Meer geïsoleerd gelegen populaties - relictpopulaties na habitatverlies dan wel nieuwe vestigingen buiten het oorspronkelijke verspreidingsgebied - vertonen een lagere genetische variatie en een meer afwijkende genetische samenstelling. De resultaten van circa twintig jaar geleden uit eigen land suggereren dat dezelfde genetische patronen zich hier op veel kleiner schaalniveau afspelen. Dit als gevolg van het veel intensievere landgebruik en de sterkere fragmentatie van het leefgebied. Al met al lijkt de genetische connectiviteit en vitaliteit van heikikkerpopulaties dus duidelijk nadelige gevolgen te ondervinden van onderbrekingen in hun leefgebied. Lijnvormige infrastructuur kan daarbij aantoonbaar een rol spelen als barrière voor uitwisseling, al komen studies tot nu toe tot wisselende conclusies over de mate waarin deze barrièrewerking optreedt en blijkt uit de literatuur tot dusver niet duidelijk hoe verschillende typen (spoor)wegen hierin van elkaar verschillen.

\section{Populatie-genetisch onderzoek heikikker}

Hoewel de genetische verschillen beperkt zijn, is er binnen het studiegebied sprake van een genetische structuur, waarbij zowel de deelpopulatie ten westen van de spoorlijn Weesp-Almere en die in de Ankeveense Plassen verschilt van de deelpopulaties in het Naardermeer. Het genetische verschil tussen de deelpopulaties in het Naardermeer en die in de Ankeveense Plassen maakt het naar verwachting mogelijk om bij een toekomstige effectmeting een effect van de twee in 2013 gerealiseerde faunapassages in de provinciale weg te meten. Het geringe genetische verschil tussen de twee deelpopulaties in het Naardermeer - respectievelijk ten noorden en zuiden van de spoorlijn maakt het lastig om bij een toekomstige effectmeting een effect van eventuele verbeterde uitwisseling via de nieuwe faunapassages in de spoorlijn waar te nemen. Het genetische verschil tussen de deelpopulatie ten westen van de spoorlijn Weesp-Almere en de deelpopulaties in het Naardermeer maakt het naar verwachting mogelijk om bij een toekomstige effectmeting een effect van eventuele verbeteringen aan de bestaande ecoduiker in deze spoorlijn en/of de habitat rond het uitwateringskanaal te meten.

\section{Advies effectstudie heikikker}

Het gegeven dat er nauwelijks genetische verschillen zijn tussen heikikkers ten noorden en ten zuiden van de spoorlijn door het Naardermeer maakt dat een effectstudie - dus een herhaling van het hier uitgevoerde genetisch onderzoek enkele jaren nadat de faunapassages in gebruik zijn genomen geen optie is om het functioneren van de nieuwe faunapassages in de spoorlijn te meten. Het genetische verschil tussen de deelpopulaties in het Naardermeer en die in de Ankeveense Plassen maakt een dergelijke effectstudie naar verwachting wel mogelijk. De deelpopulaties zijn op dit moment genetisch nog duidelijk van elkaar te onderscheiden. Als dit verschil op termijn verdwijnt door uitwisseling via de twee gerealiseerde faunapassages in de provinciale weg, dan is dit naar verwachting goed te meten. Datzelfde geldt, hoewel in mindere mate, voor de al langer bestaande faunapassage in de spoorlijn Weesp-Almere. Omdat hier naar verwachting niet alleen de barrièrewerking van de spoorlijn maar ook de afstand een rol speelt, is hier in eerste instantie nader onderzoek gewenst naar de verspreiding van de soort direct rondom deze faunapassage en het gebruik ervan. 


\section{Advies effectstudie ringslang}

De ringslang is in potentie een geschikte soort voor een effectstudie gebaseerd op een vergelijking van de situatie vóór en na opening van faunapassages, maar dit is slechts zinvol als blijkt dat in het voorstadium inderdaad sprake is van een genetisch verschil aan weerszijden van de infrastructurele barrière. Dit pleit voor een aanpak zoals uitgevoerd voor de heikikker, waarbij wordt gestart met een nulmeting om de huidige genetische patronen van de ringslang in het studiegebied te achterhalen. Wanneer de nulmeting een ruimtelijke populatiestructuur laat zien die gerelateerd lijkt aan de (barrièrewerking van) infrastructuur, is na enkele jaren een effectmeting zinvol. De aanbeveling is dus om een populatie-genetische studie naar de ringslang in de Vechtstreek min of meer hetzelfde vorm te geven als de studie voor heikikker, met enkele aanpassingen:

- Het studiegebied uitbreiden, waarbij ook de leefgebieden van de ringslang ten noorden van rijksweg A1 in de studie worden betrokken. Dit biedt de kans om ook de barrièrewerking van deze snelweg te onderzoeken en de functionaliteit van hier, relatief recent, aangelegde faunapassages.

- Binnen ieder deelgebied minimaal 25 DNA-monsters van ringslangen verzamelen tijdens de nulmeting. Daarnaast is het verzamelen van minimaal 10 DNA-monsters in minimaal drie referentiegebieden van belang. Deze referentiegebieden verschillen bij voorkeur wat betreft afstand tot het studiegebied. Daarnaast is de aanbeveling om data van buitenlandse studies naar dezelfde soort te gebruiken als referentie.

- Bij het verzamelen van de DNA-monsters tijdens de nulmeting ervoor zorgen dat per deelgebied minimaal 5 van de monsters op korte afstand van de gerealiseerde faunapassages, of zelfs daarin, worden verzameld.

- Bij het verzamelen van DNA-monsters vier methoden gebruiken: (1) vangen van (sub)adulte dieren op zicht, bijvoorbeeld op het moment dat de dieren uit hun winterslaap komen en zonnige plekken opzoeken, (2) vangen van dieren met behulp van uitgelegde kunstmatige schuilplekken, (3) verzamelen van eischalen in voor dit doel strategisch gesitueerde broeihopen en (4) verzamelen van vervellingshuiden en dode dieren.

- In aanvulling op de voor de heikikker gebruikte analyses, voor de ringslang ook kijken naar verwantschappen van individuele dieren.

- Het advies is om vijf jaar na de nulmeting een effectmeting te doen, mits in de nulmeting een ruimtelijke populatiestructuur is vastgesteld waarbij populaties in de deelgebieden voldoende genetische differentiatie vertonen. 


\section{$1 \quad$ Inleiding}

\subsection{Achtergrond}

De provincie Noord-Holland werkt aan het versterken van de ecologische samenhang tussen de diverse laagveenmoerassen in de Vechtstreek door de aanleg van natuurverbindingen. Het passeerbaar maken van infrastructurele barrières voor plant en dier is daarbij een belangrijke opgave. Verkeers- en spoorwegen hebben een versnipperende werking in het landschap. Enerzijds omdat ze een barrière vormen voor dieren die zich door het landschap willen bewegen, waardoor (delen van) leefgebieden onbereikbaar worden en genetische uitwisseling tussen populaties wordt belemmerd, anderzijds omdat dieren die toch proberen te passeren de kans lopen om te worden aangereden. Wegen en spoorwegen die natuurgebieden doorkruisen, zijn daarbij extra risicovol, zoals de provinciale weg N236 die tussen het Naardermeer en de Ankeveense plassen ligt, of de spoorlijn tussen Amsterdam en Hilversum die het Naardermeer doorsnijdt (Figuur 1).

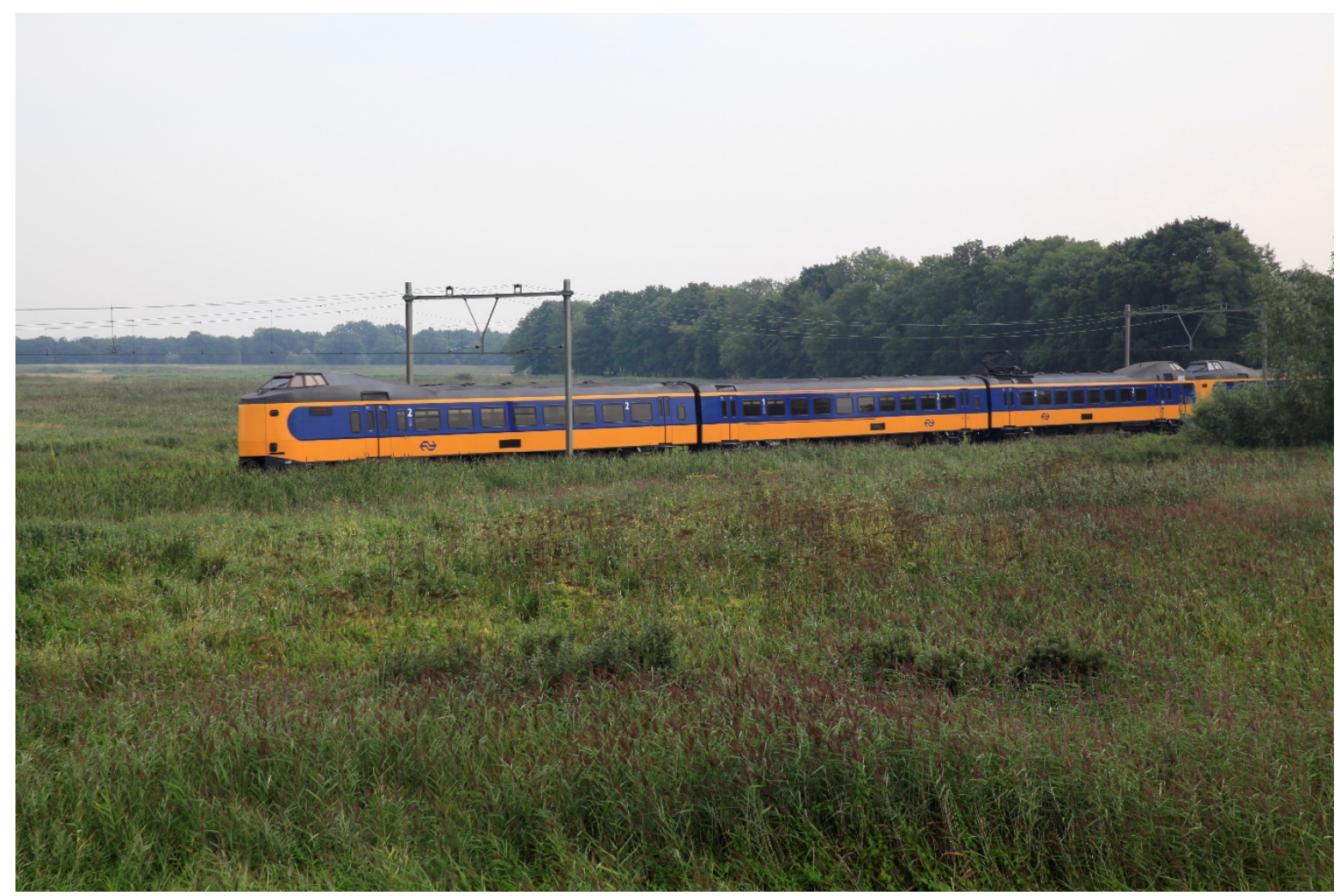

Figuur 1 De spoorlijn van Amsterdam naar Hilversum door het Naardermeer is de eerste spoorlijn die is aangelegd door de Nederlandsche Rhijnspoorweg-Maatschappij - tegenwoordig Nederlandse Spoorwegen - en vormt een belangrijke schakel in het Nederlandse spoorwegnetwerk.

(c) Foto: Edgar van der Grift.

Al in 1994 presenteerde de Vereniging Natuurmonumenten een plan om de ecologische samenhang van het Naardermeer en de Ankeveense Plassen te versterken. Een van de suggesties was om daarvoor een gedeelte van de N236 op palen te zetten, zodat dieren de weg ongestoord en veilig kunnen passeren (Veen \& Jorna, 1994). Om dit idee verder uit te werken, is er destijds een variantenstudie uitgevoerd en zijn vervolgens twee varianten in detail uitgewerkt, die vooral verschilden in de manier hoe met de barrièrewerking van de 's-Gravelandse Vaart werd omgegaan (Oranjewoud, 1998; Provincie Noord-Holland, 2004). In beide varianten was het voorstel om op twee 
plekken in de N236 een robuuste faunapassage aan te leggen, 50-75 m breed en 2,5 m hoog. Deze voorstellen zijn vervolgens ecologisch getoetst, met als centrale vraag of de voorgestelde faunapassages aan de eisen voldoen die de doelsoorten van de natuurverbinding aan dergelijke passages stellen. De conclusie van deze toetsing was dat het type faunapassage geschikt is voor de doelsoorten, maar dat de onderdoorgangen minimaal $4 \mathrm{~m}$ hoog moeten zijn en er een vide van minimaal $10 \mathrm{~m}$ breed tussen de rijbanen moet komen om vegetatieontwikkeling in de faunapassage mogelijk te maken (Van der Grift, 2004). In 2006 is het werk voorbereid, bestaande uit twee 75 m brede faunapassages, het deels verleggen en herinrichten van de 's-Gravelandse Vaart en natuurontwikkeling binnen het aanliggende terrein, de Hilversumse Bovenmeent. In 2007 is met de aanleg van de faunapassages begonnen. Deze zijn officieel in gebruik genomen in oktober 2013 (Figuur 2).

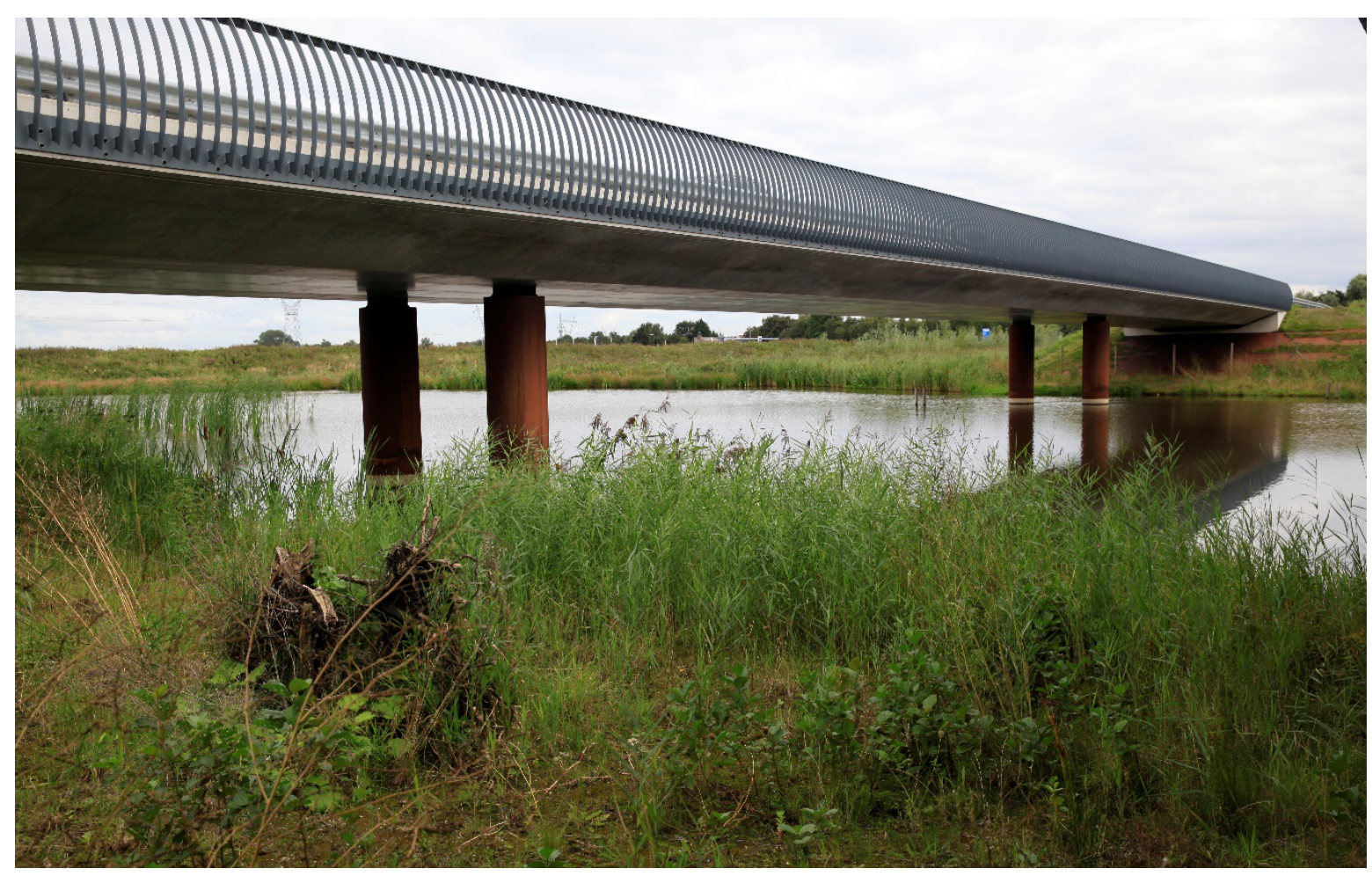

Figuur 2 De westelijke faunapassage - Natrixpassage genoemd - in de N236.

(C) Foto: Edgar van der Grift.

In 1997 zijn de eerste voorstellen gedaan om de versnipperende werking van de spoorlijn in het Naardermeer te mitigeren (Van der Grift \& Aartsen, 1997). In 2009 is hier, in opdracht van Natuurmonumenten, verdere uitwerking aan gegeven. Aanvankelijk was het idee om één ruim gedimensioneerde onderdoorgang te realiseren in het westelijke deel van het Naardermeer (Movares, 2009). In 2013 zijn de voorontwerpen voor een dergelijk robuust kunstwerk geëvalueerd en is vastgesteld dat er voor de meeste doelsoorten in het gebied meer ecologische winst te halen is als er niet één, maar meerdere tunnels verspreid over de diverse biotopen van het Naardermeer worden aangelegd. In 2014 is daarom, opnieuw in opdracht van Natuurmonumenten, een Ontsnipperingsplan Naardermeer opgesteld, waarin systematisch is geanalyseerd wat de diverse doelsoorten nodig hebben en welke aanbevelingen ten aanzien van het aantal en ontwerp van de faunapassages kunnen worden gegeven (Van der Grift \& Ottburg, 2014). Op basis van dit onderzoek is geadviseerd om 21 faunapassages te realiseren. In een volgende stap is de technische en financiële haalbaarheid van het ontsnipperingsplan verkend, in een samenwerking tussen ProRail, de provincie Noord-Holland en Natuurmonumenten. Hieruit bleek dat de aanleg van negen faunapassages haalbaar was: acht faunapassages uit het ontsnipperingsplan, aangevuld met faunavoorzieningen bij de brug over de Karnemelksloot. Het betreft twee bruggen met doorlopende oevers, één ecoduiker, drie kleine droge faunatunnels, looprichels bij twee bestaande bruggen en een faunaloopstrook in een fietstunnel (Voormeerpassage). Deze negen faunapassages zijn in 2019 aangelegd (Figuur 3). 

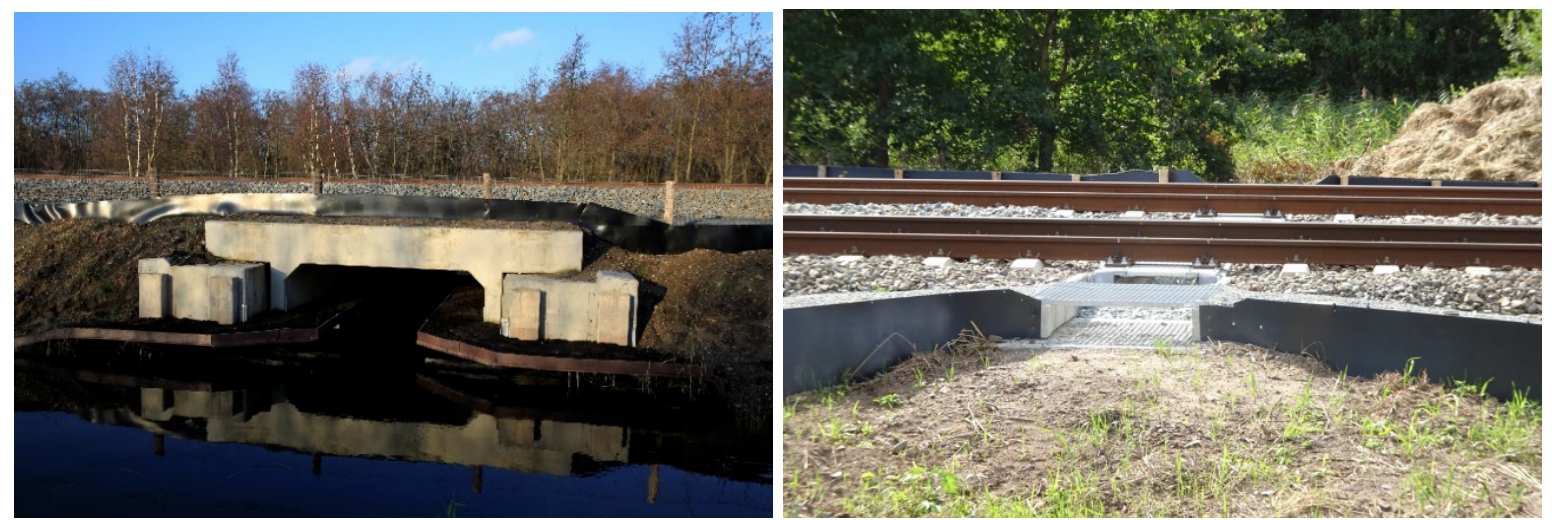

Figuur 3 Twee van de faunapassage in de spoorlijn die het Naardermeer doorsnijdt. (c) Foto's: Edgar van der Grift (links); Fabrice Ottburg (rechts).

De ontsnipperende maatregelen bij zowel de N236 als de spoorlijn in het Naardermeer vormen een belangrijke schakel in het streven naar meer ecologische samenhang in het laagveengebied. Ze helpen om de natuurgebieden van de Vechtstreek intern te ontsnipperen, onderling te verbinden en te koppelen aan de randmeren en Waterland. Hiermee vervullen ze een belangrijke functie in de realisatie van de 'natte as' in het Nationaal Natuurnetwerk. Figuur 4 geeft de ligging weer van de gerealiseerde faunapassages in de N236 en de spoorlijn in het Naardermeer.

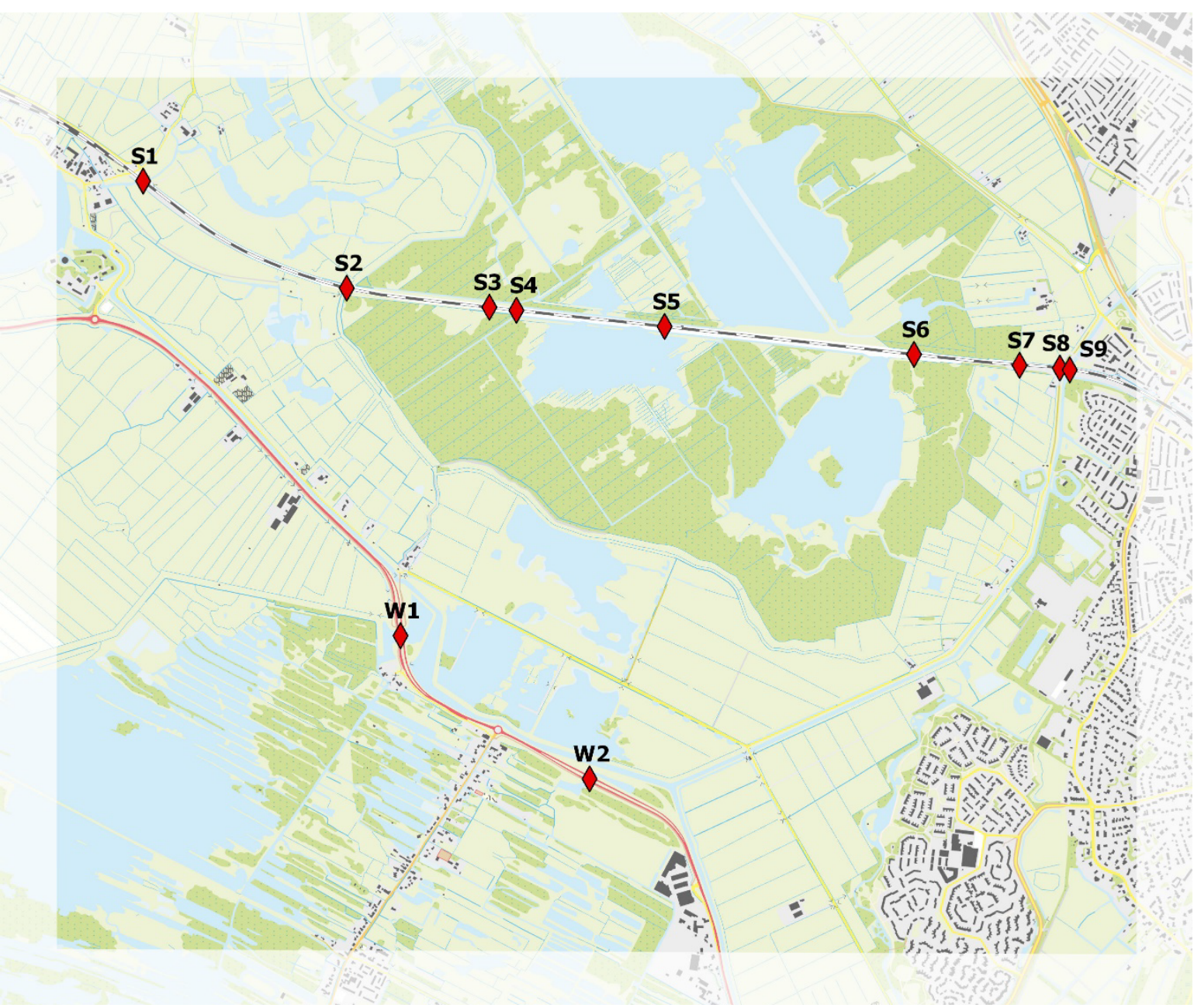

Figuur 4 Ligging van de faunapassages in de N236 en de spoorlijn die het Naardermeer doorsnijdt. Het betreft looprichels onder bestaande brug (S1, S4), duiker met looprichels (S3), brug met doorlopende oevers en droge loopstroken (S5, S9, W1, W2), kleine faunatunnel in ballastbed ('dwarsligger') (S2, S6), kleine droge faunatunnel (S7), recreatieve tunnel met faunastrook (Voormeerpassage) (S8). 
De provincie Noord-Holland is benieuwd naar het functioneren van de gerealiseerde faunapassages. Maken de diersoorten waarvoor ze bedoeld zijn er ook gebruik van? Eén manier om de functionaliteit van faunapassages te onderzoeken, is het meten van uitwisseling van individuen tussen populaties aan weerszijden van de infrastructuur met behulp van genetische technieken. Voor dergelijk onderzoek is het echter van belang dat er voldoende grote genetische verschillen zijn vóór - of kort na - de aanleg van de faunapassages. In dit kader heeft de provincie Noord-Holland aan Wageningen Environmental Research gevraagd om te verkennen of voor de heikikker (Rana arvalis) aan deze voorwaarde wordt voldaan en of genetische monitoring van deze soort inzicht kan bieden in de effectiviteit van de gerealiseerde ontsnipperende maatregelen bij de N236 en de spoorlijn door het Naardermeer. Een tweede vraag van de provincie is of de ringslang (Natrix helvetica) een geschikte soort is om de effectiviteit van faunapassages aan te tonen middels genetisch onderzoek. Dergelijk onderzoek naar zowel heikikker als ringslang kan, indien uitvoerbaar, wellicht model staan voor soortgelijke evaluaties voor andere doelsoorten.

\subsection{Heikikker in de Vechtstreek}

De heikikker is een beschermde inheemse diersoort onder de Wet Natuurbescherming en tevens opgenomen in bijlage IV van de EU-Habitatrichtlijn en bijlage II van de Conventie van Bern. De soort heeft in de Rode Lijst de status Thans niet bedreigd. De soort komt vooral voor in hoog- en laagveengebieden, vochtige heide, voedselarme tot matig voedselrijke vennen en beekjes, blauwgraslanden, broek- en ooibossen, beek- en rivierdalen en uiterwaarden. In de veenweidegebieden en het rivierengebied komt de soort ook in extensief beheerd agrarisch grasland voor. De soort komt voor in alle provincies, behalve in Flevoland. Binnen Noord-Holland is de Vechtstreek voor de heikikker een belangrijk kerngebied, met het meest westelijk gelegen verspreidingsgebied in de Bloemendalerpolder en de westelijk daarvan gelegen Gemeenschapspolder. Binnen de provincie Noord-Holland komt de heikikker niet verder naar het westen toe voor, met uitzondering van het eiland Texel (Herder, 2010; Ottburg \& Bugter, 2017).

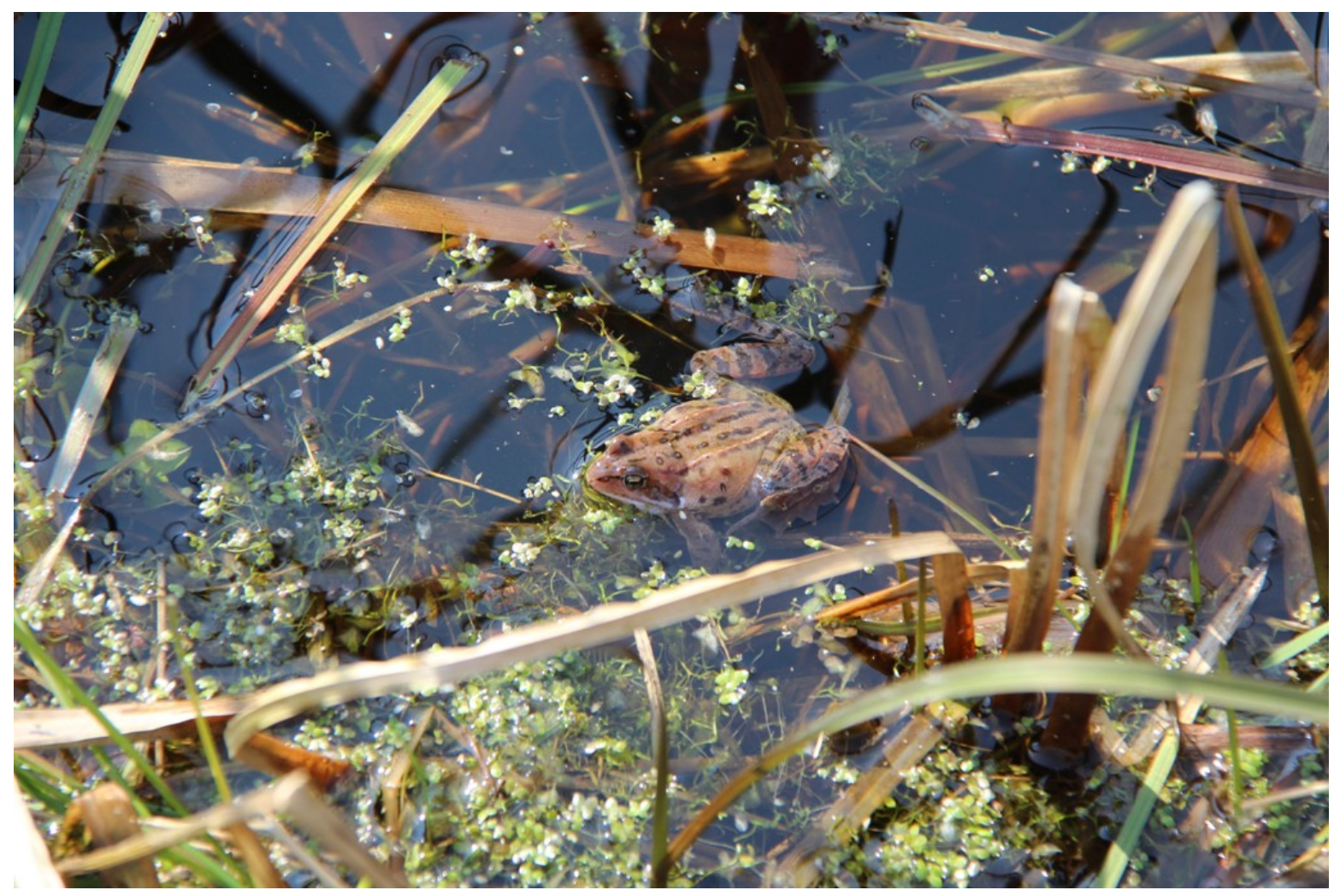

Figuur 5 Zoekbeeld van een heikikker (Rana arvalis) in sloten. (c) Foto: Fabrice Ottburg. 
De soort komt verspreid over de Vechtstreek voor, zowel in het Naardermeer als in de omliggende polders en de Vechtplassen (Figuur 5 en 6). Op basis van een recente inventarisatie naar het voorkomen van de heikikker in het Naardermeer en de aangrenzende polders lijkt sprake te zijn van meerdere lokale (deel)populaties (Goverse \& Creemers, 2018). In totaal zijn er tijdens deze inventarisatie 459 heikikkers waargenomen. Dit betrof vooral juveniele dieren. De hoogste dichtheden werden gevonden langs de ringdijk rond het Naardermeer en langs de Melkmeent. Heikikkers zijn ook gevonden op de geïsoleerde percelen in het centrale deel van het Naardermeer die tijdens de inventarisatie per boot bezocht zijn, maar de dichtheid was daar betrekkelijk laag. In de omliggende polders zijn relatief hoge aantallen heikikkers aangetroffen in het oostelijke deel van de Heintjesraken Broekerpolder. In de Keverdijksche Overscheensche Polder en Ondermeent zijn relatief weinig waarnemingen gedaan. In de Nieuwe Keverdijksche Polder is de soort vooral gevonden langs het uitwateringskanaal van het Naardermeer en ten zuiden van de Reaalpolderweg en de spoorlijn.
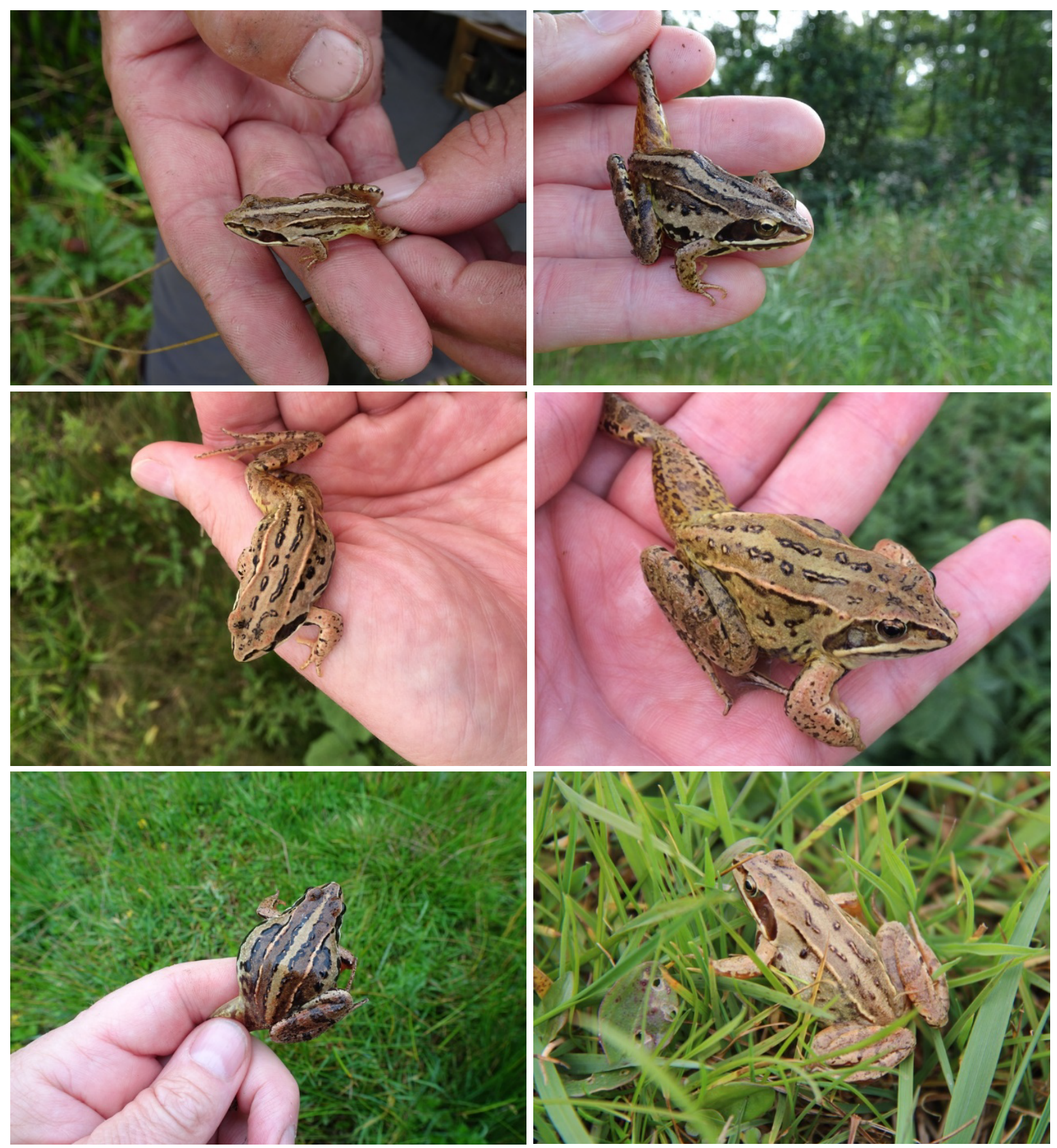

Figuur 6 Heikikkers zijn individueel herkenbaar aan hun lichte streep over de rug en de twee lichte ruglijsten die parallel over de rug lopen. Daarnaast hebben heikikkers in tegenstelling tot de bruine kikker (Rana temporaria), waarmee ze vaak worden verwisseld, een spitse snuit en een grotere metatarsusknobbel (graafknobbel). (c) Foto's: Fabrice Ottburg. 
Het verspreidingsvermogen van de heikikker is beperkt. Volwassen dieren leggen meestal afstanden af tot $500 \mathrm{~m}$ van het voortplantingswater. Juvenielen bewegen zich tot circa $1000 \mathrm{~m}$ van het voortplantingswater. Verkeers- en spoorwegen vormen voor deze soort een potentiële barrière en dragen bij aan de fragmentatie van leefgebieden (Vos \& Chardon, 1998; Van der Grift et al., 2009). Daarnaast bestaat het risico dat de dieren sterven door aanrijdingen wanneer zij deze infrastructuur oversteken (Hels \& Buchwald, 2001). Onduidelijk is daarom in hoeverre de verschillende lokale populaties in de Vechtstreek met elkaar in verbinding staan, dus waartussen uitwisseling van individuen bestaat, of geheel geïsoleerd zijn.

Er zijn vooralsnog geen empirische studies verricht naar het effect van faunapassages op de uitwisseling tussen populaties van de heikikker. Modelsimulaties hebben wel laten zien dat faunapassages in potentie de levensvatbaarheid van versnipperde populaties kunnen vergroten (Pontoppidan \& Nachman, 2013). De heikikker is niet specifiek genoemd als doelsoort voor beide faunapassages in de N236, maar de soort profiteert naar verwachting wel van deze ontsnipperende maatregelen. Van der Grift (2004) stelde op basis van modelanalyses vast dat het opheffen van de barrièrewerking van de N236 ertoe zal leiden dat het Naardermeer en de Ankeveense Plassen één groot stabiel leefgebied voor amfibieën - met een geringe dispersiecapaciteit en een matige oppervlaktebehoefte - gaan vormen. Hiermee is een verschuiving te verwachten in duurzaamheid van de leefgebieden, i.e. van duurzaam (zowel Naardermeer als Ankeveense Plassen) in de ongemitigeerde situatie naar sterk duurzaam na realisatie van de natuurverbindingen. De heikikker is als doelsoort aangewezen voor de ontsnippering van de spoorlijn door het Naardermeer (Van der Grift \& Ottburg, 2014). Zeven van de negen ontsnipperende voorzieningen die hier zijn gerealiseerd, zijn geschikt voor gebruik door heikikkers.

\subsection{Ringslang in de Vechtstreek}

De ringslang (Figuur 7) is een beschermde inheemse diersoort onder de Wet Natuurbescherming en bijlage III van de Conventie van Bern. De soort heeft in de Rode Lijst de status Kwetsbaar. De soort komt vooral voor in waterrijke gebieden, zowel op zandgronden als op de overgangen van zandgrond naar veen- en kleigronden. Polders vormen belangrijke foerageergebieden voor ringslangen in de lente, zomer en het najaar, maar deze foerageergebieden dienen in de nabijheid van droge locaties te liggen, zodat de dieren droog kunnen overwinteren in hun hibernacula. Primair zijn dit de polders die in de buurt van natuurlijke overgangen van hoog en droog naar laag en nat liggen. Secundair wordt dit in het huidige landschap ook gevormd door dijken, spoorbanen en wegbermen, waardoor het verspreidingsgebied van de ringslang langzaam maar zeker steeds meer opschuift richting het westen van het land (ook door (on)bedoelde introducties). De soort komt voor in alle provincies, maar de belangrijkste leefgebieden liggen momenteel in de provincies boven de grote rivieren. Binnen NoordHolland is de Vechtstreek voor de ringslang een belangrijk kerngebied. 


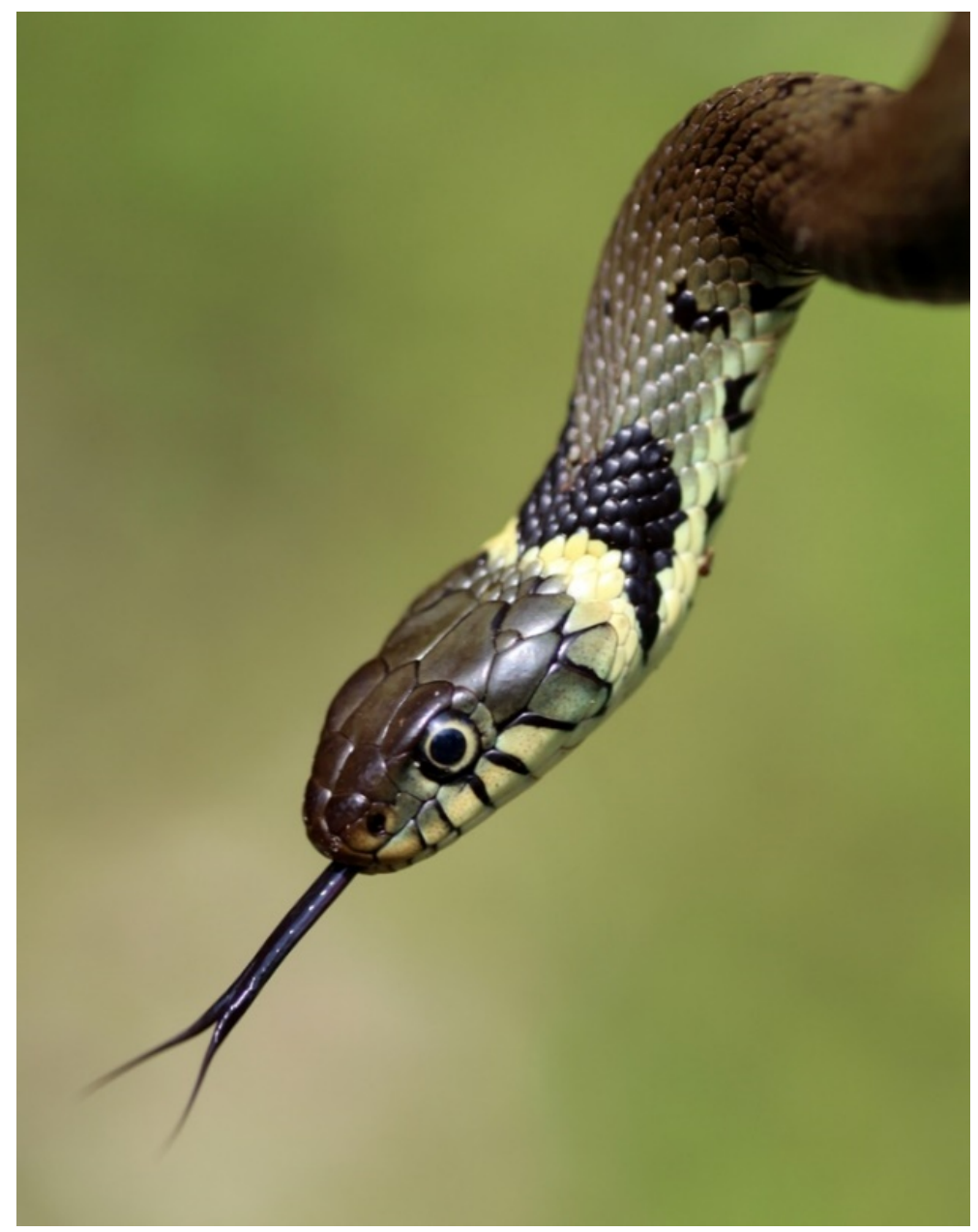

Figuur 7 Het Naardermeer is belangrijk leefgebied voor de ringslang (Natrix helvetica) in NoordHolland. (c) Foto: Fabrice Ottburg.

In de Vechtstreek is de soort verspreid over het Naardermeer, de Ankeveense Plassen en de omringende polders waargenomen (Van der Grift, 2004; Goverse \& Creemers, 2018). In totaal zijn er tijdens de inventarisatie in 201842 ringslangen waargenomen. De vondsten zijn verspreid over het hele gebied gedaan. Plekken waar meerdere dieren zijn aangetroffen, zijn langs de Reaalspolderweg, het Ton Storkpad, het uitwateringskanaal van het Naardermeer, de Meerkade, de Melkmeent, bij Stadszigt en in het oostelijke deel van de Heintjesrak- en Broekerpolder.

Het verspreidingsvermogen van de ringslang is groter dan die van de heikikker. De dieren kunnen zich op een dag tot $100 \mathrm{~m}$ verplaatsen. Over het gehele seizoen wordt door volwassen dieren een afstand van 3-4 km afgelegd. Tijdens het zoeken naar nieuw leefgebied leggen juveniele dieren soms nog grotere afstanden af. Verkeers- en spoorwegen kunnen ook voor deze soort een barrière vormen (Van der Grift et al., 2009). Gezien de relatief dichte infrastructuur in de Vechtstreek is het voor de ringslang daarom niet duidelijk in hoeverre de verschillende lokale populaties met elkaar in verbinding staan en genetische uitwisseling kennen.

De ringslang is specifiek genoemd als doelsoort voor beide faunapassages in de N236. Van der Grift (2004) stelde op basis van modelanalyses vast dat het opheffen van de barrièrewerking van de N236 ertoe zal leiden dat het Naardermeer en de Ankeveense Plassen één groot stabiel leefgebied voor kleine diersoorten - met een matige dispersiecapaciteit en een matige oppervlaktebehoefte - gaan vormen, dat kan worden gekarakteriseerd als sterk duurzaam. De ringslang is als doelsoort aangewezen voor de ontsnippering van de spoorlijn door het Naardermeer (Van der Grift \& Ottburg, 2014). Zeven van de negen ontsnipperende voorzieningen die hier zijn gerealiseerd, zijn geschikt voor gebruik door ringslangen. 


\subsection{Potentiële meerwaarde populatie-genetisch onderzoek}

Populatie-genetisch onderzoek kan meer inzicht geven in de vraag of in de Vechtstreek sprake is van genetische verschillen tussen de verschillende populaties van de heikikker. Dergelijke genetische verschillen zijn indicatief voor de mate van isolatie van populaties. Eerder genetisch onderzoek naar Drentse populaties van de heikikker liet zien dat de genetische verschillen beperkt waren bij populaties op enkele kilometers afstand van elkaar, maar dat infrastructurele barrières meer invloed hadden dan absolute afstand (Vos et al., 2001). Dit doet vermoeden dat de aanleg van faunapassages voor deze amfibiesoort inderdaad waardevol kan zijn. Het is echter goed mogelijk dat in een habitattype dat sterk verschilt van die in Drenthe, zoals de laagveenplassen in de Vechtstreek, de mogelijkheden voor uitwisseling van individuen tussen heikikkerpopulaties aanzienlijk anders zijn.

Populatie-genetisch onderzoek kan ook meer inzicht geven in de effectiviteit van ontsnipperende maatregelen. Het kan aantonen of faunapassages bijdragen aan het vermengen van genetische eigenschappen van de populaties aan weerszijden van een (voormalige) infrastructurele barrière. Een belangrijk doel van ontsnippering is om migratie van soorten naar andere gebieden (al dan niet bewoond) en uiteindelijk genetische uitwisseling mogelijk te maken. Het vaststellen van genetische uitwisseling is dus een goede parameter voor het bepalen van het succes van ontsnipperende maatregelen. Van belang bij dit type onderzoek is de uitvoering van een meting voorafgaand aan het nemen van een maatregel, ook wel nulmeting genoemd. In een later stadium kan dan een tweede meting - de zogenoemde effectmeting - worden uitgevoerd om te zien of de genetische verschillen zijn verminderd sinds de maatregel is getroffen.

\subsection{Doel van het onderzoek}

Het doel van het onderzoek is drieledig:

- Het uitvoeren van een nulmeting van de huidige genetische kenmerken van heikikkers in de

- Vechtstreek.

- Het opstellen van een advies voor een effectmeting waarmee het functioneren van de aangelegde faunapassages voor de heikikker kan worden geëvalueerd.

- Het opstellen van een advies voor een effectstudie waarmee het functioneren van de aangelegde faunapassages voor de ringslang kan worden geëvalueerd.

\subsection{Onderzoeksvragen}

Om deze doelen te bereiken, richten we ons in het onderzoek op de volgende vragen:

1. Wat is er nationaal en internationaal bekend over de genetische eigenschappen van heikikkers? Zijn er verschillen tussen populaties?

2. Bestaan er verschillen in genetische eigenschappen tussen populaties heikikkers in de Vechtstreek?

3. Hoe kan, op basis van het huidige onderzoek, in de toekomst vastgesteld worden of er vermenging van genetische eigenschappen van populaties heeft plaatsgevonden ten gevolge van de aanleg van de faunavoorzieningen? En na hoeveel jaar zou dergelijk onderzoek moeten plaatsvinden?

4. In hoeverre is, gezien zijn verspreidingsvermogen, de ringslang een geschikte soort om de effectiviteit van faunapassages aan te tonen middels genetisch onderzoek? En indien dit mogelijk is, hoe dient dit onderzoek er dan uit te zien? 


\subsection{Aanpak van het onderzoek}

Voor de beantwoording van de eerste onderzoeksvraag is een literatuuronderzoek uitgevoerd. We hebben ons hierbij primair gericht op informatie in de wetenschappelijke literatuur.

Voor de beantwoording van de tweede onderzoeksvraag is populatie-genetisch onderzoek uitgevoerd, waarvoor DNA-monsters van heikikkers zijn verzameld in het Naardermeer en de direct omliggende polders en natuurgebieden. Op basis van de genetische analyses is vervolgens verkend of er verschillen in genetische kenmerken zijn tussen de verschillende populaties in het gebied.

Voor de beantwoording van de derde onderzoeksvraag is - mede op basis van de literatuurstudie en het verrichte populatie-genetisch onderzoek - een plan van aanpak opgesteld voor een genetische studie naar de bijdrage van de faunavoorzieningen aan de vermenging van genetische eigenschappen in de Vechtstreek. Onze zienswijze, en uitgangspunt voor het plan van aanpak, is dat een dergelijke effectstudie dient te bestaan uit een vergelijking van de genetische verschillen op twee meetmomenten: een nulmeting ( $t=0$; idealiter voorafgaand aan of tenminste kort na aanleg van de faunavoorzieningen) en een effectmeting $(t=1)$ in een later stadium, i.e. enige jaren nadat de faunavoorzieningen door heikikkers in gebruik is genomen.

Voor de beantwoording van de vierde onderzoeksvraag is voor de ringslang verkend welk genetisch onderzoek is verricht naar verspreidingsvermogen en ruimtelijke genetische variatie in deze soort. Hiervoor is een beknopte literatuurscan uitgevoerd, waarin zowel de huidige verspreiding van de ringslang in de Vechtstreek als publicaties van eerder populatie-genetisch onderzoek in binnen- en buitenland zijn meegenomen. De uitkomsten hiervan zijn gebruikt als basis voor de beoordeling van de waarde en aanpak van een populatie-genetische studie naar de bijdrage van de faunavoorzieningen aan de genetische vermenging van de ringslang-populaties in het gebied.

\subsection{Leeswijzer}

Hoofdstuk 2 presenteert de uitkomsten van het literatuuronderzoek naar genetische eigenschappen van heikikkers en mogelijke verschillen tussen populaties. Hoofdstuk 3 beschrijft de methode en resultaten van het uitgevoerde populatie-genetisch onderzoek naar heikikkers in en rond het Naardermeer. Hoofdstuk 4 en 5 presenteren vervolgens een advies voor het uitvoeren van een genetische effectstudie voor respectievelijk de heikikker en ringslang, met als doel de functionaliteit van de gerealiseerde faunavoorzieningen vast te stellen. 


\section{Review literatuur heikikker}

\section{$2.1 \quad$ Inleiding}

In dit hoofdstuk verkennen we wat er bekend is over de genetische eigenschappen van heikikkers en eventuele verschillen tussen populaties. We betrekken hierbij de resultaten van genetisch onderzoek uit binnen- en buitenland. Voor een toelichting op enkele in dit hoofdstuk gebruikte populatiegenetische begrippen verwijzen wij naar de Begrippenlijst achter in dit rapport.

\section{$2.2 \quad$ Werkwijze}

Met behulp van een concrete set zoektermen is naar relevante publicaties gezocht in de literatuurdatabases Biological Abstracts, Current Contents en Zoological Records. Hierbij zijn de zoektermen 'moor frog' of 'rana arvalis' gecombineerd met 'genetic(s)', 'DNA', 'genotype' of 'gene flow'. De referentielijsten in de op deze wijze gevonden publicaties zijn geraadpleegd om publicaties op te sporen die niet via genoemde databases zijn achterhaald. De literatuurlijst is vervolgens verder aangevuld met publicaties uit persoonlijke databases. Door deze werkwijze zijn naar verwachting de recentste onderzoeksresultaten uit binnen- en buitenland verkregen.

\subsection{Bevindingen}

\subsubsection{Genetische variatie in heikikkerpopulaties}

Binnen Nederland is genetisch onderzoek naar heikikkers uitgevoerd in twee hoogveengebieden in respectievelijk Drenthe en Noord-Brabant (Vos et al., 2001; Arens et al., 2007). Hierbij zijn DNAmonsters geanalyseerd die in 1999 zijn verzameld. Deze studie liet zien dat, bij vergelijking van de twee gebieden, zowel de genetische variatie als de heterozygositeit relatief laag was in de populaties in Noord-Brabant. Deze populaties waren relatief klein van omvang en kenden een sterkere isolatie als gevolg van intensiever agrarisch landgebruik en meer infrastructuur in het tussenliggende gebied. Het feit dat het landgebruik in Noord-Brabant pas relatief recent is veranderd en daarvoor meer vergelijkbaar was met de situatie in Drenthe, doet vermoeden dat sprake is van een verlies aan variatie in Noord-Brabantse populaties in de loop van de $20^{\mathrm{e}}$ eeuw, al is niet uit te sluiten dat er altijd al een verschil in variatie was tussen de twee gebieden (Arens et al., 2007). Onbekend is hoe de genetische status van de heikikkerpopulaties in deze twee gebieden sinds 1999 is veranderd, bijvoorbeeld door natuurherstel, de ontwikkeling van natuurverbindingen en door aanleg van ontsnipperende maatregelen bij verkeers- en spoorwegen.

Buiten Nederland is genetisch onderzoek naar heikikkers verricht in Centraal-Europa en Scandinavië. Rafinski \& Babik (2000) onderzochten de genetische samenstelling van heikikkerpopulaties in Centraal-Europa. Zij vergeleken daarbij populaties in de laaglanden van Zuid-Polen ten noorden van de Karpaten met populaties in de Pannonische laagvlakte van Hongarije en Roemenië en een geïsoleerde populatie in de zuidelijke Karpaten. Zij vonden een verschil in gemiddelde heterozygositeit (de mate van genetische variatie binnen een individu en een indicatiewaarde voor de kans op inteelt) en de allelenrijkdom (de mate van genetische variatie in de populatie als geheel) tussen beide populaties. Noordelijke populaties lieten significant hogere (en daarmee gunstigere) waarden zien dan zuidelijke populaties. Dit is naar verwachting een gevolg van een verschil in verspreiding tijdens het Pleistoceen. In die periode was de Pannonische laagvlakte onafgebroken bewoond door heikikkers, maar dat gold niet voor de gebieden ten noorden van de Karpaten. Een uitzondering vormde de geïsoleerde populatie in de zuidelijke Karpaten; hier werden significant lagere waarden gemeten voor 
beide maten voor genetische variatie. Deze populatie is naar verwachting een relict van een veel grotere populatie, maar is door isolatie en afname in grootte veel genetische variatie verloren.

Knopp et al. (2007) vonden een duidelijk lagere genetische variatie in heikikkerpopulaties op eilanden voor de Zweedse kust dan op het Zweedse vasteland. In een tweede genetische studie voor een groot aantal Scandinavische populaties van de heikikker vonden Knopp \& Merilä (2009a) een relatief lage variatie in het noorden van Zweden, die zij verklaarden via het relatief recente ontstaan van deze populaties. Als een beperkt aantal individuen een nieuwe plek koloniseert, is de variatie in eerste instantie beperkt tot de genotypen die zij samen meebrachten en komen pas mettertijd nieuwe migranten binnen die aanvullende variatie meebrengen, een patroon dat een 'founder effect' wordt genoemd. Dit zou tevens betekenen dat de variatie verder zuidwaarts, richting het centrum van het verspreidingsgebied van de heikikker, hoger zou zijn. Knopp \& Merilä (2009a) vonden inderdaad een hogere variatie in centraal-Scandinavië, echter in het zuiden (Denemarken) nam de variatie weer af. Hier lijkt sprake van een recente genetische erosie door het krimpen van populaties als gevolg van toenemende menselijke activiteit in het gebied. De resultaten van beide studies ondersteunen het uit de populatie-genetische literatuur bekende beeld dat kleine, geïsoleerde populaties een lagere genetische diversiteit herbergen dan grotere populaties of sterk verbonden (deel)populaties (o.a. Frankham, 1997; 1998).

\subsubsection{Genetische verschillen tussen heikikkerpopulaties}

De Nederlandse studie in Drenthe en Noord-Brabant heeft meer inzicht verschaft in genetische patronen op kleine geografische schaal (Arens et al., 2007). De genetische verschillen tussen populaties bleken relatief beperkt in Drenthe ten opzichte van Noord-Brabant. De waarde voor genetische differentiatie $\left(F_{s t}\right)$ was in Drenthe gemiddeld 0,022, tegenover 0,060 in Noord-Brabant. Binnen beide gebieden lagen de populaties slechts enkele kilometers uit elkaar. Binnen beide Nederlandse studiegebieden is een patroon van het zogenoemde 'isolatie door afstand' aangetroffen, wat aangeeft dat de populaties nog wel een zekere mate van genetische uitwisseling kenden, maar dat deze uitwisseling significant afnam over een afstand van slechts enkele kilometers. Naast de correlatie van de genetische afstand tussen populaties met alleen geografische afstand, berekenden Vos et al. (2001) en Arens et al. (2007) ook de correlatie met meer complexe schattingen van de mate van weerstand in het landschap tussen twee populaties. Wanneer ook het aantal tussenliggende lijnvormige barrières (wegen en/of spoorwegen) werd meegenomen in de analyse, vonden Vos et al. (2001) dat dit de genetische afstand tussen de Drentse populaties iets beter verklaarde (correlatie van $r=0,37$, significantie $p=0,022$ ) dan wanneer alleen de geografische afstand tussen de populaties werd meegenomen $(r=0,31, p=0,042)$. Zulke lijnvormige infrastructuur leek hier dus bij te dragen aan de genetische isolatie van populaties. In Noord-Brabant had een model waarin naast geografische afstand ook de aanwezigheid van lijnvormige landschapselementen was opgenomen geen duidelijke extra verklarende waarde ten opzichte van een model met alleen geografische afstand (beide een correlatie van $r=0,69$; Arens et al., 2007), wat echter ook kan komen doordat deze factoren onderling sterk correleerden, zodat hun effecten lastig van elkaar te scheiden waren. Of verschillende typen lijnvormige elementen, zoals $\mathrm{N}$-wegen, snelwegen en spoorwegen, onderling verschillen in hun effect op het ontstaan van genetische variatie bij heikikkers, bleef in deze studies onduidelijk.

De Centraal-Europese heikikkerpopulaties bleken genetisch relatief veel van elkaar te verschillen (Rafinski \& Babik, 2000), met $F_{\text {st }}$ waarden van 0,124 en 0,078 voor respectievelijk de zuidelijke en noordelijke populaties. Dit is te verklaren via de flink grotere onderlinge afstanden: in beide regio's lagen de bemonsterde populaties op een onderlinge afstand van ten minste 100, tot maximaal $500 \mathrm{~km}$ van elkaar. Circa $40 \%$ van de variatie tussen de diverse bemonsteringslocaties kan worden toegeschreven aan variatie binnen de regio, terwijl de overige circa $60 \%$ van de variatie een gevolg is van de verschillen tussen de noordelijke en zuidelijke regio. Isolatie door afstand werd alleen vastgesteld binnen de zuidelijke regio. Dit indiceert dat de noordelijke populaties pas (relatief) recent hun oorspronkelijke verspreidingsgebied weer hebben gekoloniseerd (Rafinski \& Babik, 2000). Een gerichte studie naar de kolonisatieroutes van de heikikker in dit deel van Europa ondersteunde deze hypothese (Babik et al., 2004). 
Ook de door Knopp et al. (2007) aangetroffen genetische verschillen tussen populaties in Zweden waren relatief hoog, wat ook hier niet verrassend is gezien de grote afstanden tussen de populaties (ten minste $110 \mathrm{~km}$, tot maximaal $660 \mathrm{~km}$ ). Echter, zelfs op deze geografische schaal was zichtbaar dat de eilandpopulaties bijna twee keer zo sterk afweken van de populaties op het vasteland als de populaties op het vasteland onderling. Voor populaties op het vasteland lieten Knopp \& Merilä (2009a) zien dat op een schaal van 100 tot $1000 \mathrm{~km}$ zowel voor heikikker als bruine kikker de genetische verschillen lineair toenamen met toenemende afstand tussen de populaties. Zo'n 'isolatie door afstand'-relatie wordt bij veel diersoorten waargenomen, maar verdwijnt vaak op een groter schaalniveau als onderlinge afstanden te groot worden voor onderlinge uitwisseling. Overigens lieten Knopp \& Merilä (2009a) zien dat bij heikikkerpopulaties de onderlinge genetische verschillen op dezelfde afstand duidelijk lager waren dan bij bruine kikkers, wat aangeeft dat bij heikikkers sprake is van meer genetische uitwisseling. Op nog grotere geografische schaal vonden Knopp \& Merilä (2009b) voor heikikkers in Scandinavië een onderscheid tussen een westelijke en een oostelijke genetische lijn, die waarschijnlijk bestaat sinds de laatste ijstijd. In Noord-Zweden zijn deze lijnen met elkaar vermengd geraakt (Knopp \& Merilä, 2009b). Een dergelijke studie naar ruimtelijke genetische verschillen bij heikikkers op een schaal van honderden kilometers is (nog) niet beschikbaar voor het West-Europese verspreidingsgebied. Onduidelijk is dus hoe de Nederlandse populaties zich genetisch verhouden tot populaties in onze buurlanden.

\subsection{Conclusies}

De hierboven beschreven resultaten van studies naar heikikkerpopulaties in Noord- en Oost-Europa indiceren dat heikikkers van nature in staat zijn om enige mate van uitwisseling in stand te houden over grote afstand, tussen populaties die soms honderden kilometers van elkaar zijn verwijderd, zolang deze populaties zich bevinden in een aaneengesloten landschap bestaande uit geschikte habitat. Meer geïsoleerd gelegen populaties - relictpopulaties na habitatverlies dan wel nieuwe vestigingen buiten het oorspronkelijke verspreidingsgebied - vertonen een lagere variatie en een meer afwijkende genetische samenstelling. De resultaten van circa twintig jaar geleden uit eigen land suggereren dat dezelfde genetische patronen zich hier op veel kleiner schaalniveau afspelen. Dit als gevolg van het veel intensievere landgebruik en de sterkere fragmentatie van het leefgebied. Met name in Noord-Brabant was (destijds) sprake van een duidelijk lagere diversiteit en al binnen enkele kilometers een afname in connectiviteit tussen populaties. Al met al lijkt de genetische connectiviteit en vitaliteit van heikikkerpopulaties dus duidelijk nadelige gevolgen te ondervinden van onderbrekingen in hun leefgebied. Lijnvormige infrastructuur kan daarbij aantoonbaar een rol spelen als barrière voor uitwisseling, al komen studies tot nu toe tot wisselende conclusies over de mate waarin deze barrièrewerking optreedt en blijkt uit de literatuur tot dusver niet duidelijk hoe verschillende typen (spoor)wegen hierin van elkaar verschillen. 


\section{Populatie-genetisch onderzoek heikikker}

\subsection{Inleiding}

In dit hoofdstuk presenteren we de gebruikte methode, de resultaten en conclusies van het uitgevoerde populatie-genetisch onderzoek aan heikikkers in en rond het Naardermeer. De achterliggende onderzoeksvraag voor dit onderzoek is of er verschillen bestaan in genetische eigenschappen van populaties heikikkers in de Vechtstreek. Indien die er zijn, is een genetische effectstudie naar het functioneren van de gerealiseerde faunapassages naar verwachting haalbaar.

\section{$3.2 \quad$ Studiegebied}

\subsubsection{Begrenzing studiegebied}

Het studiegebied bestaat uit het Naardermeer, het noordelijke deel van de Ankeveense Plassen en de aan deze natuurgebieden grenzende polders, te weten de Keverdijksche Overscheense Polder, Heintjesrak- en Broekerpolder en Nieuwe Keverdijksche Polder (Figuur 8). Rijksweg A1 vormt de noordgrens van het studiegebied. De oostgrens wordt gevormd door de (oude) Rijksweg, de Karnemelksloot en het zuidelijk deel van de 's-Gravelandse Vaart. De zuidgrens ligt circa $1 \mathrm{~km}$ ten zuiden van de N236 ter hoogte van de Dammerkade en Stichtse kade. De westgrens is de rivier de Vecht.

Het studiegebied komt hiermee sterk overeen met het gebied waarin recent het voorkomen van heikikker en ringslang is onderzocht (Goverse \& Creemers, 2018). Een eerste verschil is dat nu ook het uiterste noorden van de Ankeveense Plassen is opgenomen, zodat een eventueel genetisch verschil tussen heikikkers ten noorden en zuiden van de N236 kan worden gemeten. Een tweede verschil is dat hier de Ondermeent - de polder ten zuiden van de Karnemelksloot, ingeklemd tussen de N236 in het westen en zuiden en de bebouwing van de Hilversums Overmeent in het oosten - niet is opgenomen in het studiegebied. De reden hiervoor is dat er tijdens de inventarisatie in 2018 nauwelijks heikikkers zijn aangetroffen (Goverse \& Creemers, 2018). 


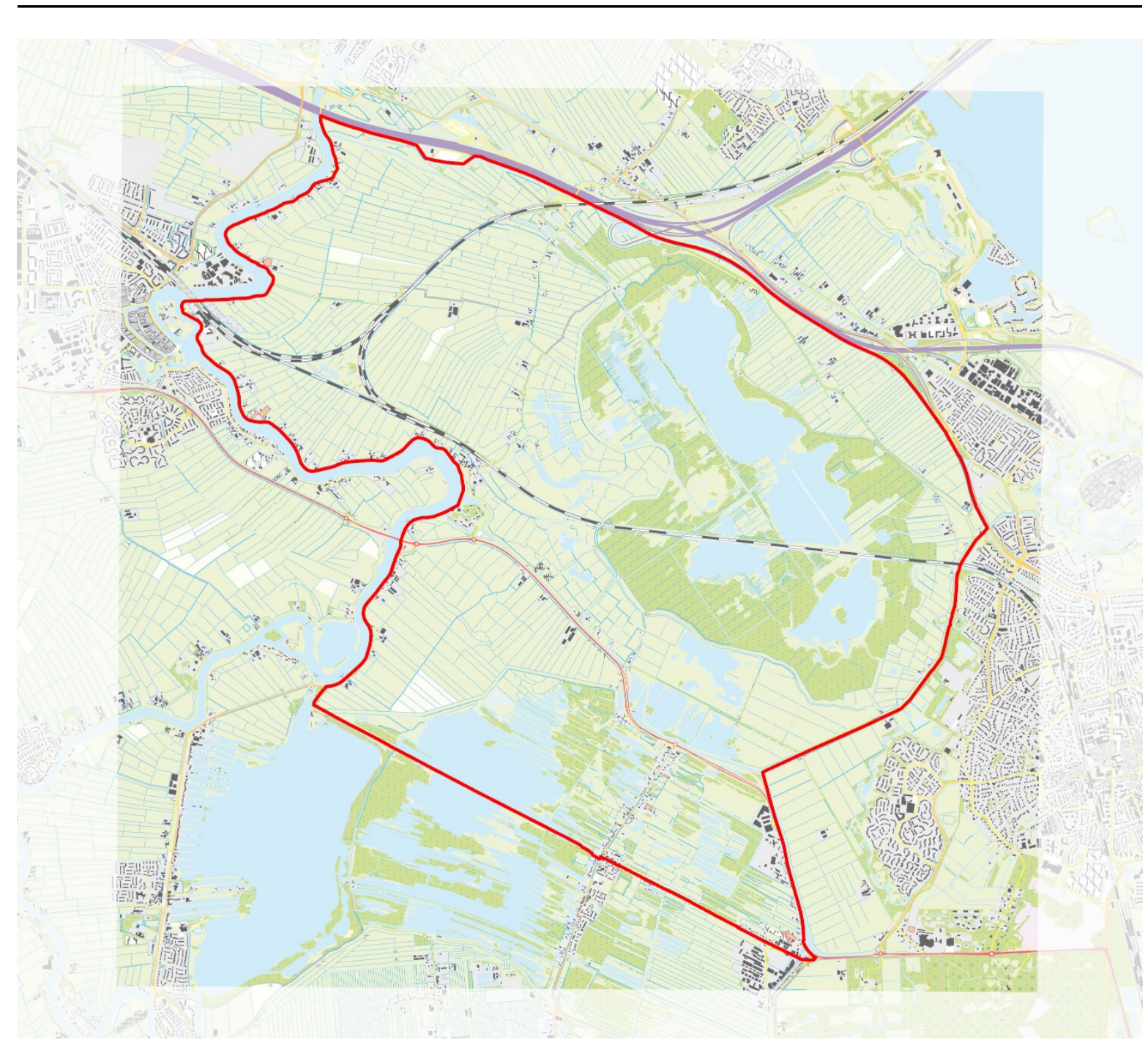

Figur 8 Ligging van het studiegebied.

\subsubsection{Beschrijving studiegebied}

De natuurgebieden Naardermeer en Ankeveense Plassen zijn plassengebieden op laagveengrond met rietland, hooiland en moerasbos (Figuur 9 en 10). Lokaal vindt hier nog laagveenvorming plaats. Het Naardermeer is bijna 1.200 ha groot, de Ankeveense Plassen zijn ruim 600 ha groot. Beide gebieden zijn in eigendom en beheer bij Vereniging Natuurmonumenten. Het gebied tussen het Naardermeer en de Ankeveense Plassen - de Hilversums Bovenmeent - is ingericht als bufferzone. Deze polder is in het kader van natuurontwikkeling plaatselijk uitgediept waardoor er plassen zijn ontstaan. Het gebied wordt extensief begraasd. De overige polders rond het Naardermeer kennen een voornamelijk agrarisch gebruik. Het betreft hier vooral rundveebedrijven. De polders bestaan dan ook voor het merendeel uit intensief grasland, doorsneden door sloten. 

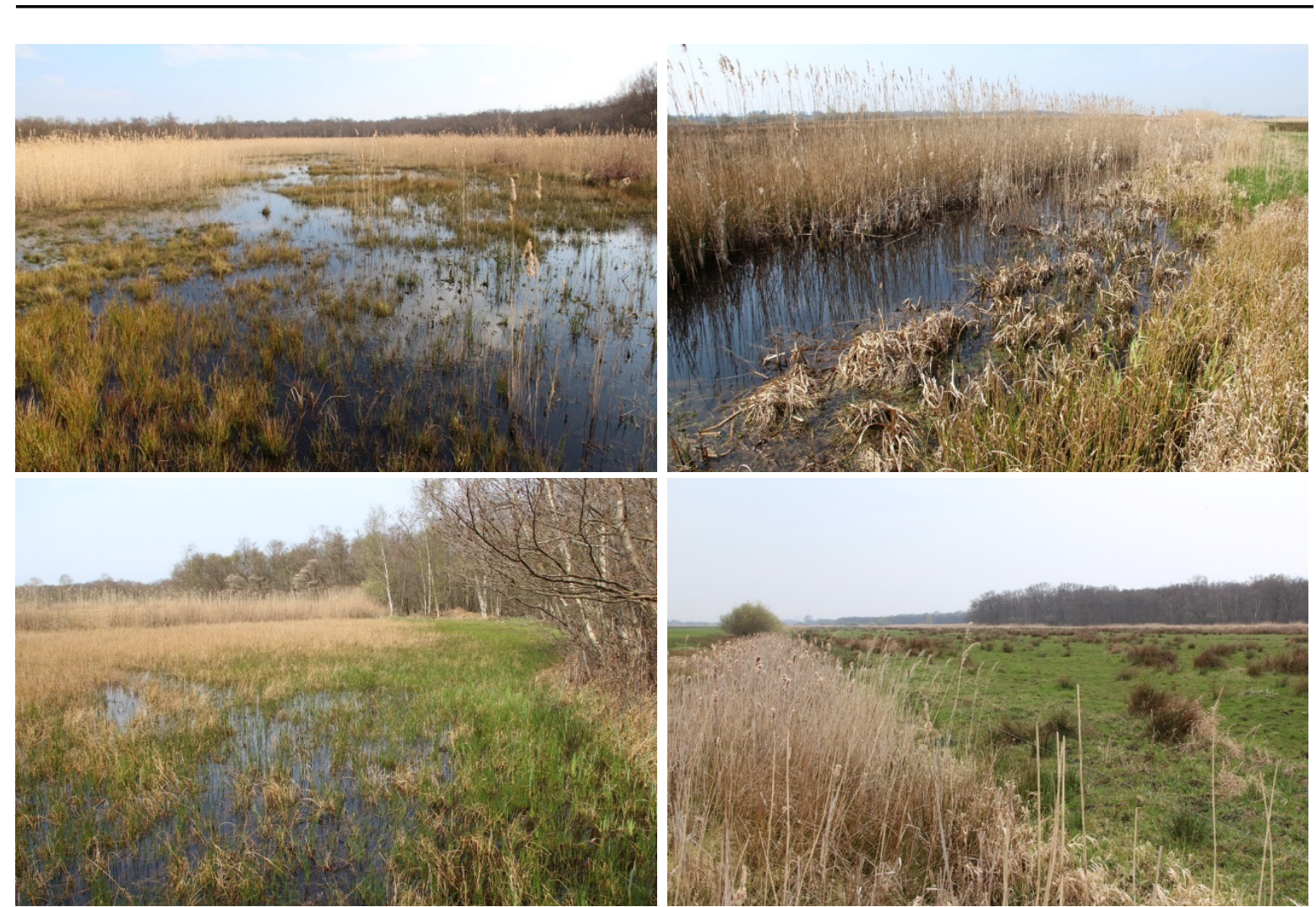

Figuur $9 \quad$ Studiegebied Naardermeer. De afbeeldingen laten habitat zien waarin ei-klompen en (juveniele) heikikkers zijn aangetroffen. (c) Foto's: Fabrice Ottburg.
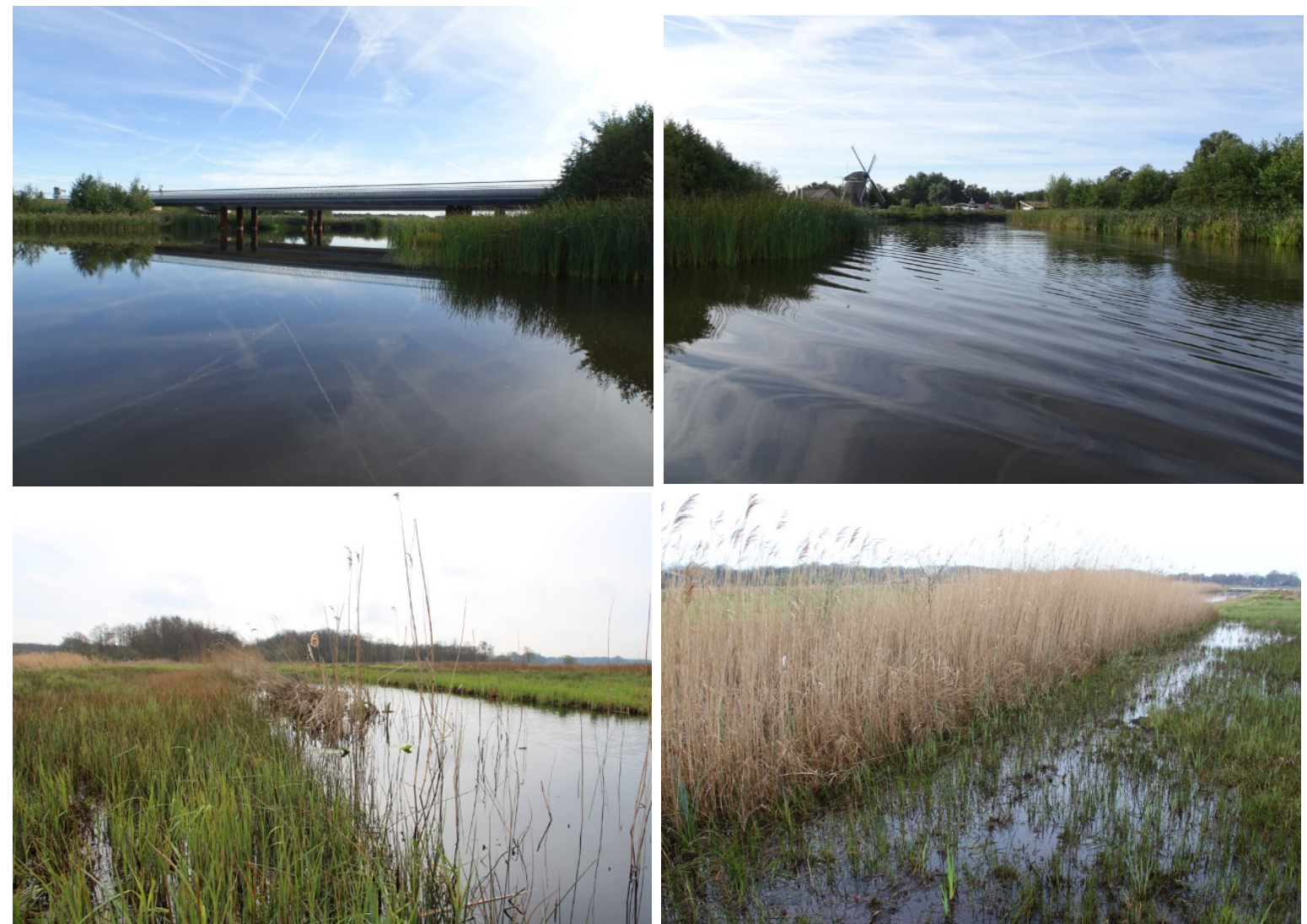

Figuur 10 Studiegebied Ankeveense Plassen. De foto linksboven laat de entree voor de heikikker zien vanuit het Naardermeer. De foto rechtsboven is de ecologische stapsteen die de heikikker moet helpen om verder het gebied in te dringen. Op de onderste foto's staat habitat waarin ei-klompen en (juveniele) heikikkers zijn aangetroffen. (c) Foto's: Fabrice Ottburg. 


\subsection{Methode}

\subsubsection{Ontwerp van de studie}

Binnen het studiegebied onderscheiden we vier deelgebieden, op basis van de compartimentering die wordt veroorzaakt door de aanwezige grootschalige infrastructuur (zie Figuur 11):

1. Deelgebied Noord-West (Stu-NW); het gebied ten noorden van de spoorlijn Weesp-Naarden en ten westen van de spoorlijn Weesp-Almere.

2. Deelgebied Noord-Oost (Stu-NO); het gebied ten noorden van de spoorlijn Weesp-Naarden en ten oosten van de spoorlijn Weesp-Almere.

3. Deelgebied Midden (Stu-M); het gebied ten zuiden van de spoorlijn Weesp-Naarden en ten noorden van de provinciale weg N236.

4. Deelgebied Zuid (Stu-Z); het gebied ten zuiden van de provinciale weg N236.

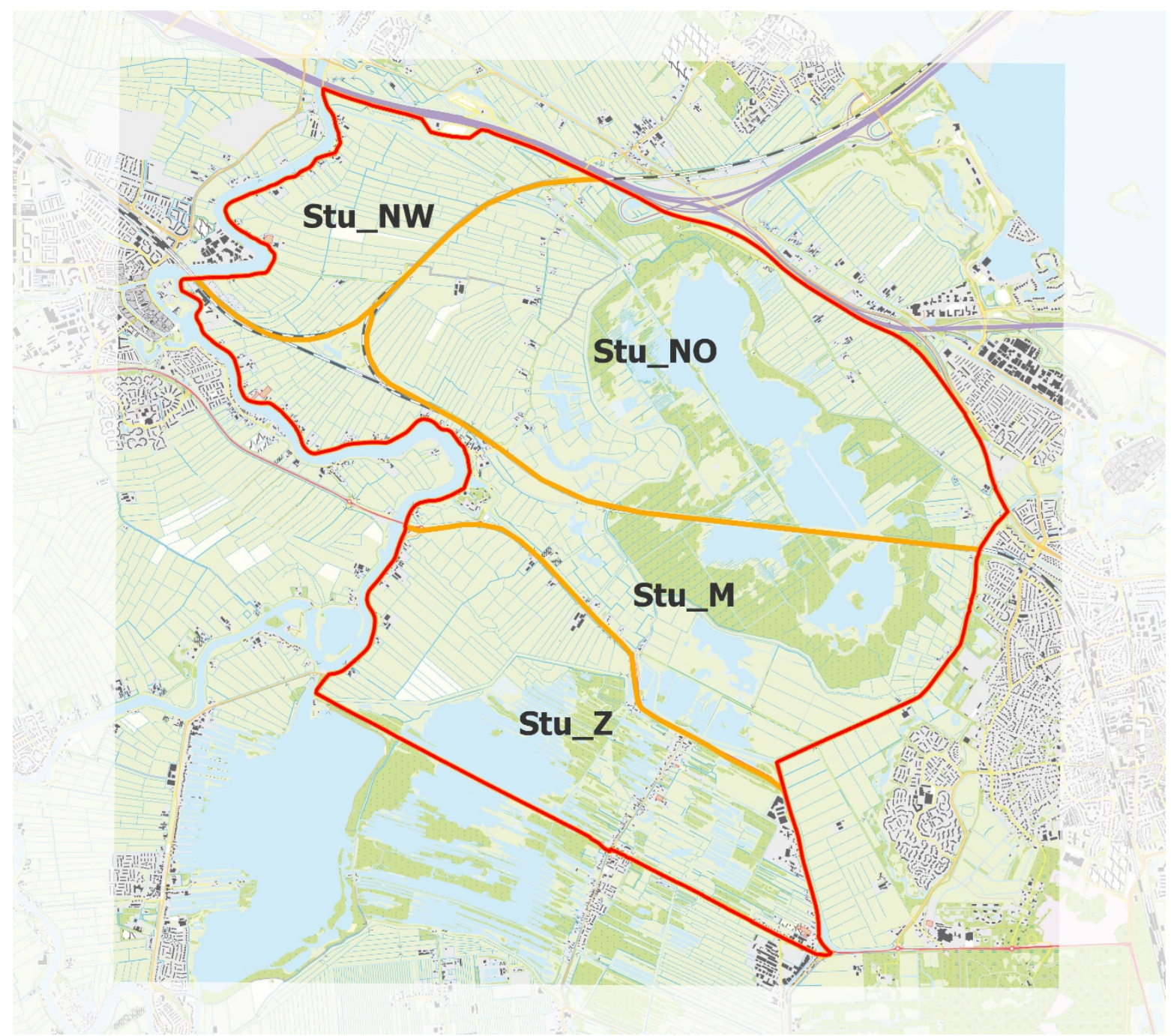

Figuur 11 Ligging van de onderscheiden deelgebieden binnen het studiegebied.

Binnen ieder deelgebied zijn DNA-monsters van heikikkers verzameld. Dit maakt het mogelijk om een goed ruimtelijk beeld te krijgen van de huidige genetische structuur van de populatie. Tevens maakt dit studieontwerp het mogelijk om eventuele effecten van de diverse infrastructuur - de spoorlijn Weesp-Naarden, de spoorlijn Weesp-Almere en de provinciale weg N236 - op de genetische variatie van de heikikker te onderzoeken. In een later stadium biedt deze werkwijze de mogelijkheid om eventuele effecten van gerealiseerde faunapassages te meten. Het streven was om minimaal 10 en bij voorkeur 25 DNA-monsters per deelgebied te verzamelen (zie Tabel 3.1 in sectie 3.3.3 voor het daadwerkelijk verzamelde aantal monsters per deelgebied). 
Naast deze monstername in het studiegebied zijn er ook DNA-monsters verzameld in referentiegebieden buiten het studiegebied. Dit betrof monsters van individuele populaties en geeft dus geen referentie voor de mate van uitwisseling met andere populaties, maar maakt het wel mogelijk om de genetische diversiteit in de populaties binnen het studiegebied in een bredere context te plaatsen: is deze hoger, lager of gelijk aan de diversiteit in populaties elders in het land. Dit is belangrijk, omdat sommige diersoorten van nature een lage diversiteit kennen in al hun populaties, terwijl andere diersoorten van nature een hoge diversiteit kennen. Om in te schatten of het aantreffen van een bepaalde genetische diversiteit reden is tot zorg of tevredenheid, is dus vergelijkingsmateriaal nodig. We hebben gekozen voor twee referentiepopulaties op relatief korte afstand van het studiegebied (1-2 km) en twee referentiepopulaties die op relatief grote afstand (circa $100 \mathrm{~km}$ ) van het studiegebied leven. Het streven was om minimaal 10 DNA-monsters per referentiepopulatie te verzamelen.

\subsubsection{Monsterlocaties in het studiegebied}

In het studiegebied komt de heikikker niet overal in hoge aantallen voor. Daarom zijn er op basis van de resultaten van Goverse \& Creemers (2018) een aantal kansrijke locaties voor het verzamelen van DNA-monsters geselecteerd (Figuur 12). Dit betreft locaties waar tijdens de inventarisatie van 2018 relatief veel heikikkers zijn aangetroffen. Tijdens de bemonstering is de aandacht in eerste instantie op deze plekken gericht geweest. Echter, ook buiten deze geselecteerde locaties is gezocht en zijn bij het aantreffen van ei-klompen en/of heikikkers DNA-monsters verzameld.

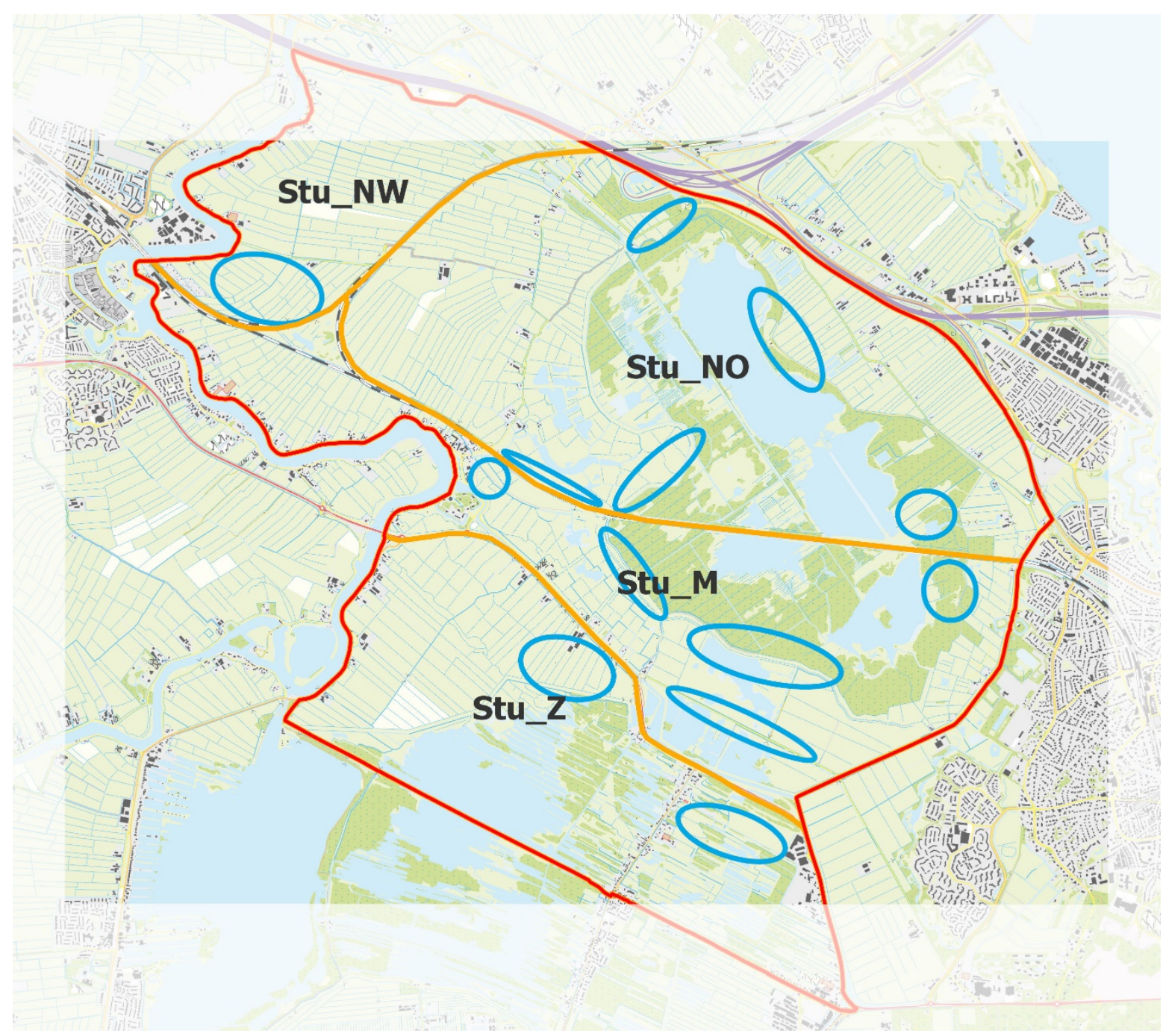

Figuur 12 De plekken in het studiegebied waar primair de aandacht naar uitging tijdens het verzamelen van DNA-monsters. 


\subsubsection{Referentiegebieden}

Tijdens dit onderzoek zijn er DNA-monsters verzameld in vier referentiegebieden:

\section{Gijzenveen (Ref-NH1)}

Referentiegebied Gijzenveen is een natuurgebied in Noord-Holland, hemelsbreed op circa $1 \mathrm{~km}$ afstand van de oostgrens van het studiegebied. Het gebied is circa 10 ha groot en ligt ingeklemd tussen de bebouwing van Bussum en de Hilversums Meent. Het gebied omvat ondiepe (veen)plassen en natte hooilanden (Figuur 13). Het gebied vormt een ecologische verbinding tussen de op de hogere zandgronden gelegen natuurgebieden van het Gooi en de laagveengebieden van de Vechtstreek, inclusief het Naardermeer. Het Gijzenveen wordt beheerd door het Goois Natuurreservaat. De in dit referentiegebied gevangen heikikkers zijn alle afkomstig uit de natte laagten en oeverzones. De populatiegrootte is onbekend ( $P$. Hulzink, Goois Natuurreservaat, persoonlijke communicatie).
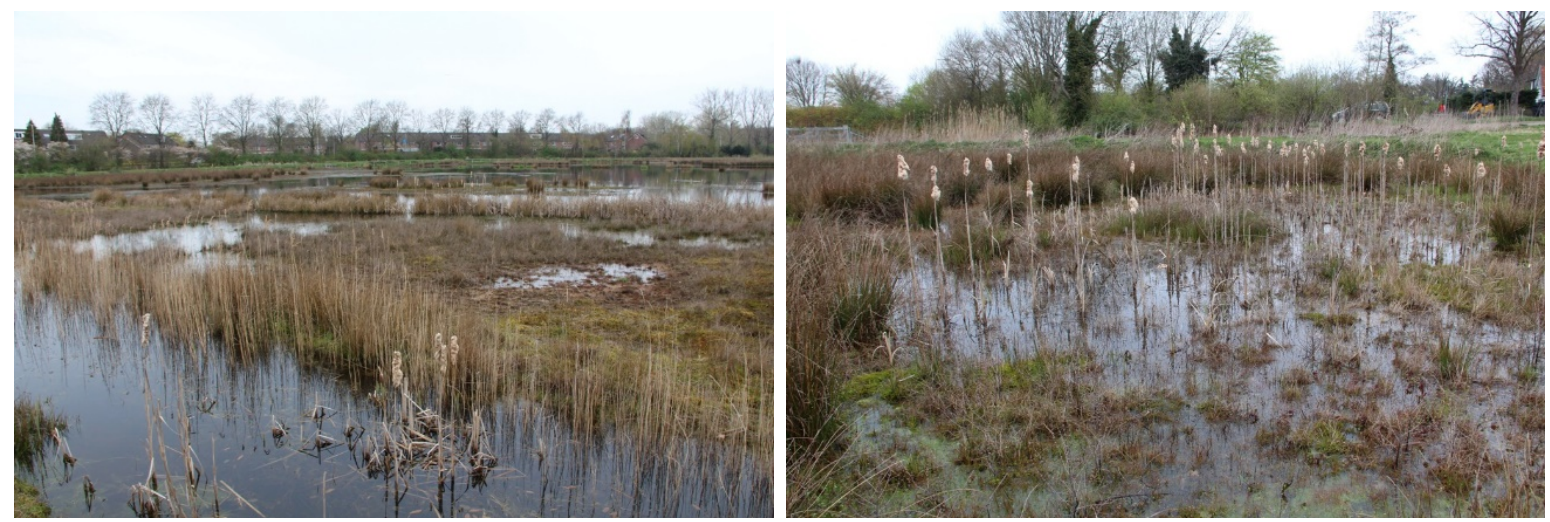

Figuur 13 Referentiegebied Gijzenveen in de provincie Noord-Holland. (c) Foto's: Fabrice Ottburg.

\section{Gemeenschapspolder-Bloemendaler Polder (Ref-NH2)}

Referentiegebied Gemeenschapspolder-Bloemendalerpolder ligt in Noord-Holland, hemelsbreed op circa $2 \mathrm{~km}$ afstand van de westgrens van het studiegebied. Het gebied is circa 300 ha groot en is begrensd door rijksweg A1 in het noorden, de korte Muidenweg in het oosten, de spoorlijn Amsterdam-Weesp in het zuiden en het Amsterdam-Rijnkanaal in het westen. Het is een landbouwgebied met overwegend intensief grasland, sloten en enkele percelen met (vochtig) loofbos (Figuur 14). De in dit referentiegebied gevangen heikikkers zijn alle afkomstig uit de sloten. De populatiegrootte is in 2017 geschat op 1.200 volwassen heikikkers (Ottburg \& Bugter, 2017).
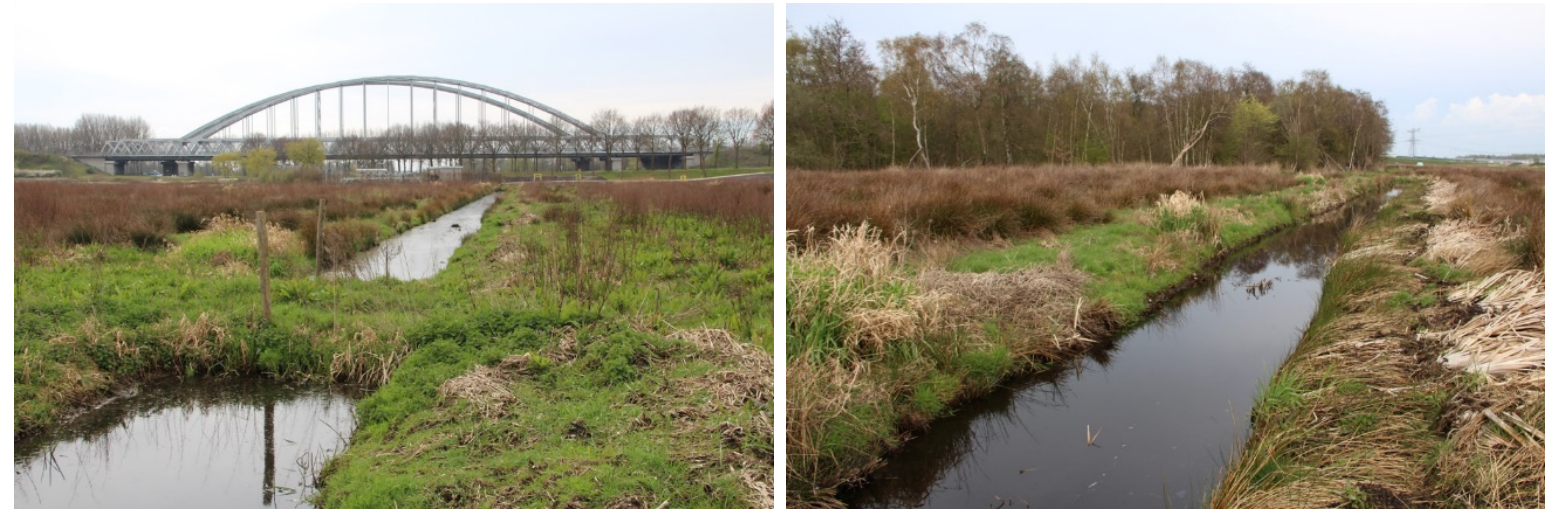

Figuur 14 Referentiegebied Gemeenschapspolder-Bloemendalerpolder in de provincie NoordHolland. (C) Foto's: Fabrice Ottburg. 


\section{Leenderheide (Ref-NB)}

Referentiegebied Leenderheide is een natuurgebied in Noord-Brabant, hemelsbreed op circa $100 \mathrm{~km}$ afstand van de zuidgrens van het studiegebied. Het gebied is ruim 300 ha groot en ligt direct onder Eindhoven, aan de oostkant van rijksweg A2. Het gebied omvat droge heide, naaldbos, loofbos en enkele vennen (Figuur 15). De Leenderheide wordt beheerd door Het Brabants Landschap. De in dit referentiegebied gevangen heikikkers zijn alle afkomstig van het Klein Huisven. De populatiegrootte is niet bekend, maar het betreft naar verwachting wel een grote, duurzame populatie. Tijdens een inventarisatie in 2009 zijn er op één avond meer dan 500 heikikkers geteld in het Klein Huisven; ook in de andere vennen op de Grote Heide zijn toen heikikkers geteld (R. Snep, WENR, persoonlijke communicatie).
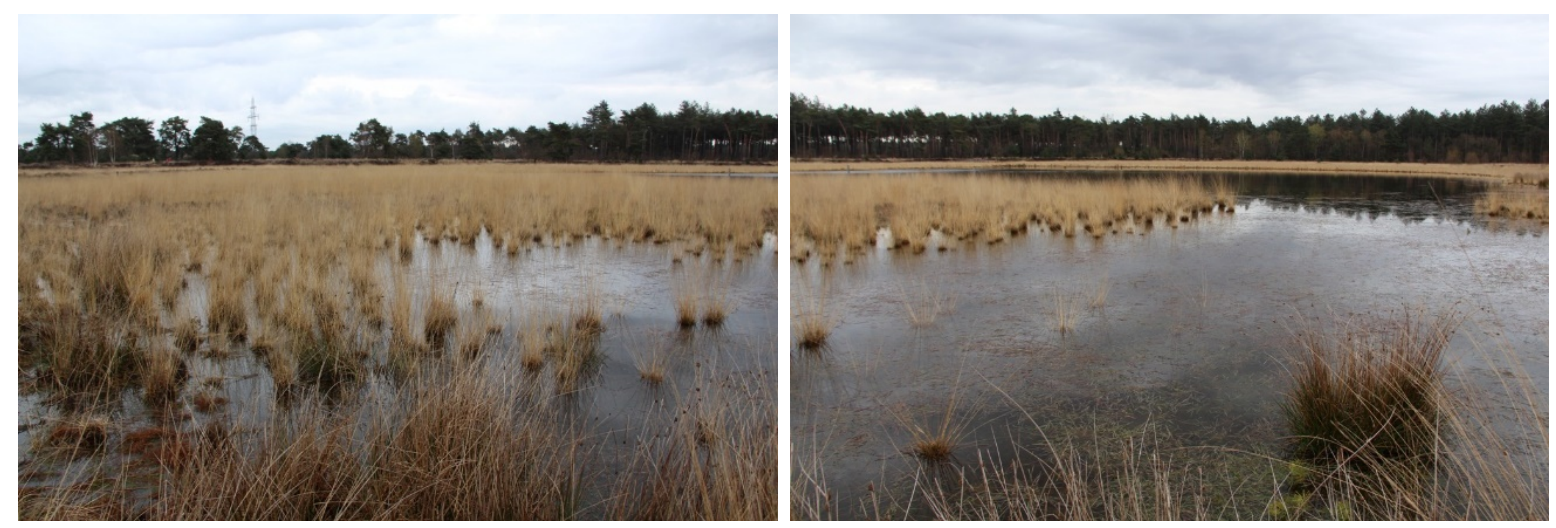

Figuur 15 Referentiegebied Leenderheide in de provincie Noord-Brabant. (c) Foto's: Fabrice Ottburg.

\section{Berger Heide (Ref-LIM)}

Referentiegebied Berger Heide is een natuurgebied in Limburg, hemelsbreed op circa $100 \mathrm{~km}$ afstand van de zuidgrens van het studiegebied. Het gebied ligt enkele kilometers ten oosten van NieuwBergen en is ruim 1200 ha groot. Het maakt deel uit van het Nationaal Park De Maasduinen. Het gebied ligt op droge rivierduinen en omvat droge heide, naaldbos, stuifzand en enkele vennen (Figuur 16). De Berger Heide wordt beheerd door de gemeente Bergen. De in dit referentiegebied gevangen heikikkers zijn alle afkomstig van het Rondven en Driessenven. De populatiegrootte is onbekend. (I. Borkent, Gemeente Bergen, persoonlijke communicatie).
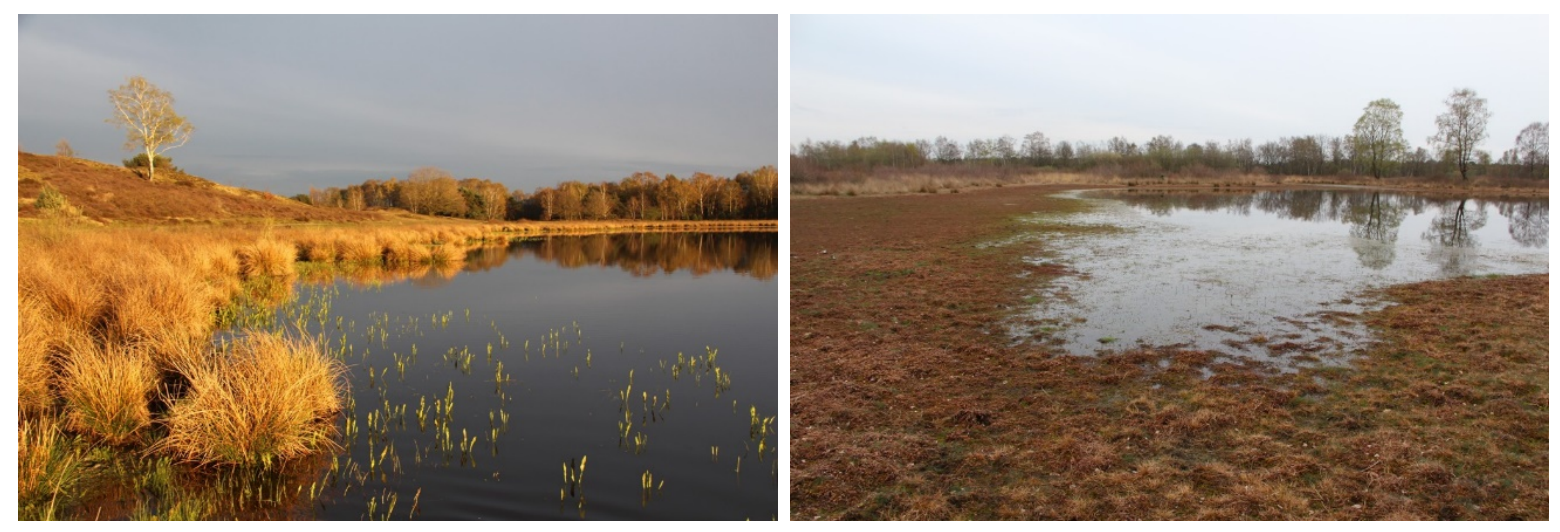

Figuur 16 Referentiegebied Berger Heide in de provincie Limburg. @ Foto's: Fabrice Ottburg.

\subsubsection{Verzamelen DNA-monsters}

De DNA-monsters zijn verzameld in twee perioden:

- Periode 1: Voorjaar (maart-april 2019)

- Periode 2: Nazomer (augustus-september 2019) 
De eerste periode valt samen met de voortplantingstijd van de heikikker. In deze periode is gezocht naar ei-klompen van de soort (Figuur 17). Per aangetroffen ei-klomp zijn 2-3 eitjes verzameld. Daarnaast is DNA verzameld van aangetroffen adulte mannelijke dieren. Hiervoor zijn swabs van de rughuid van deze dieren genomen. De tweede periode valt samen met de tijd dat het grondwaterpeil zakt en veel natte laagten en vochtige ruigten droog vallen. Heikikkers in poldergebieden - zowel adulten, subadulten als juvenielen - kunnen dan geconcentreerd in en langs de nog aanwezige wateren worden gevonden, zoals poldersloten, poelen en plassen (Goverse et al., 2014). Bovendien is dit de tijd dat juveniele heikikkers algemeen zijn en zich - het is de tijd voor dispersie - relatief goed laten zien (Van der Lugt \& Slagboom, 2016). In deze periode is DNA verzameld door het knippen van een teenkootje.
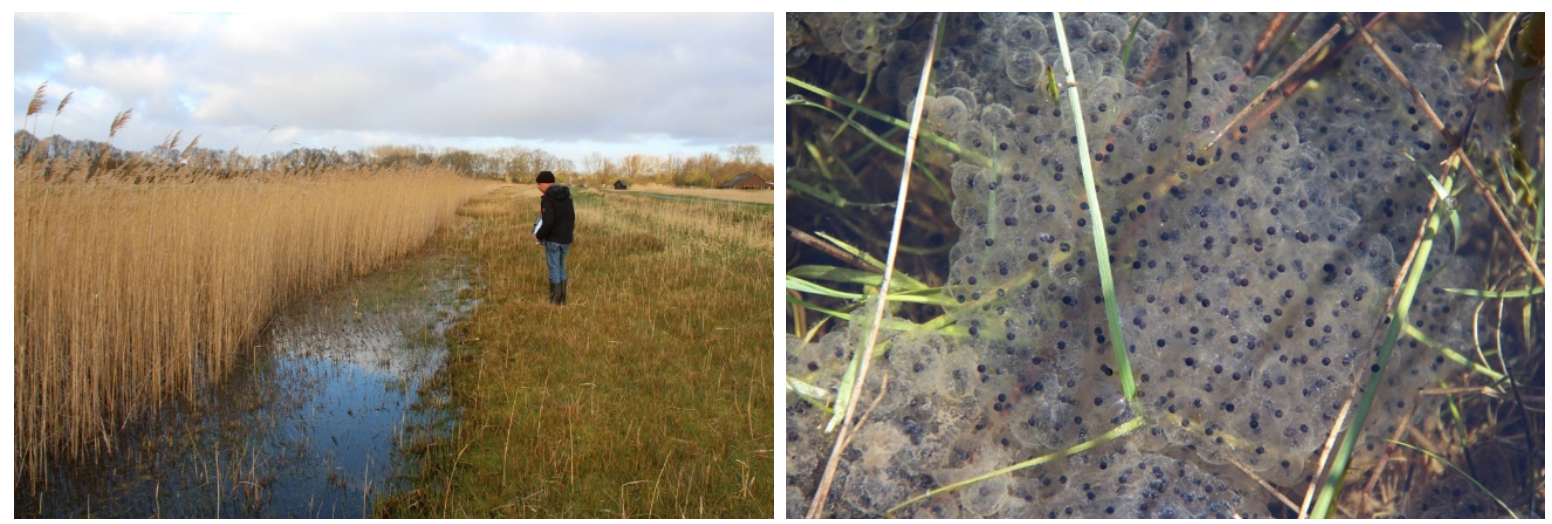

Figuur 17 Zoeken naar ei-klompen van heikikkers in het voorjaar. Rechts een voorbeeld van een ei-klomp. (c) Foto's: Fabrice Ottburg.

Het streven was om zo veel mogelijk DNA-monsters te verzamelen in de eerste periode. De tweede periode is benut om het aantal monsters aan te vullen voor deelgebieden waar in het vroege voorjaar nog onvoldoende was verzameld.

Het verzamelen van DNA uit eieren heeft een aantal duidelijke voordelen. De ei-klompen zijn goed vindbaar en bieden DNA in goede kwaliteit en kwantiteit. Daarbij komt dat verschillende ei-klompen vrijwel zeker afkomstig zijn van verschillende ouderparen. Gebruik van dit monstertype voorkomt daarmee eventuele artefacten in de resultaten door sterke verwantschap van de bemonsterde dieren. Bij bemonstering van juvenielen in de (na)zomer is de kans bijvoorbeeld groter dat op een plek nauw verwante dieren worden bemonsterd. Ten slotte voorkomt toepassing van deze methode van monstername in de voortplantingstijd ook dat er geen of weinig verstoring van adulte dieren plaatsvindt.

Tijdens de voorjaarsronde zijn met behulp van swabs vier DNA-monsters verzameld van de rughuid van (sub)adulte mannen. Deze monsters zijn gebruikt om te testen of deze methode van monstername genetische profielen van voldoende hoge kwaliteit opleveren. Indien dit het geval is, zou deze methode kunnen worden ingezet tijdens de bemonstering in de nazomer. De test wees uit dat weliswaar de kwaliteit van het verkregen DNA voldoende was voor een microsatelliet-analyse, maar dat per monster een gemengd, en daardoor onbruikbaar, profiel werd verkregen. Hoewel bewust is ingezet op swab-bemonstering van mannen - vanwege een verhoogd risico bij de vrouwen op contaminatie met DNA van mannelijke paringspartners (Müller et al., 2013) -, bleek ook hun rughuid dus vervuild met DNA van andere individuen, wat deze monstermethode te onbetrouwbaar maakt. Om die reden is tijdens de nazomer DNA verzameld door het knippen van een teenkootje (Figuur 18). ${ }^{1}$

\footnotetext{
${ }^{1}$ Deze dierexperimentele handeling is uitgevoerd onder de door de Centrale Commissie Dierproeven aan WENR verstrekte vergunning op grond van artikel 10a lid 1 van de Wet op de Dierproeven (Aanvraagnummer AVD4010020173046).
} 

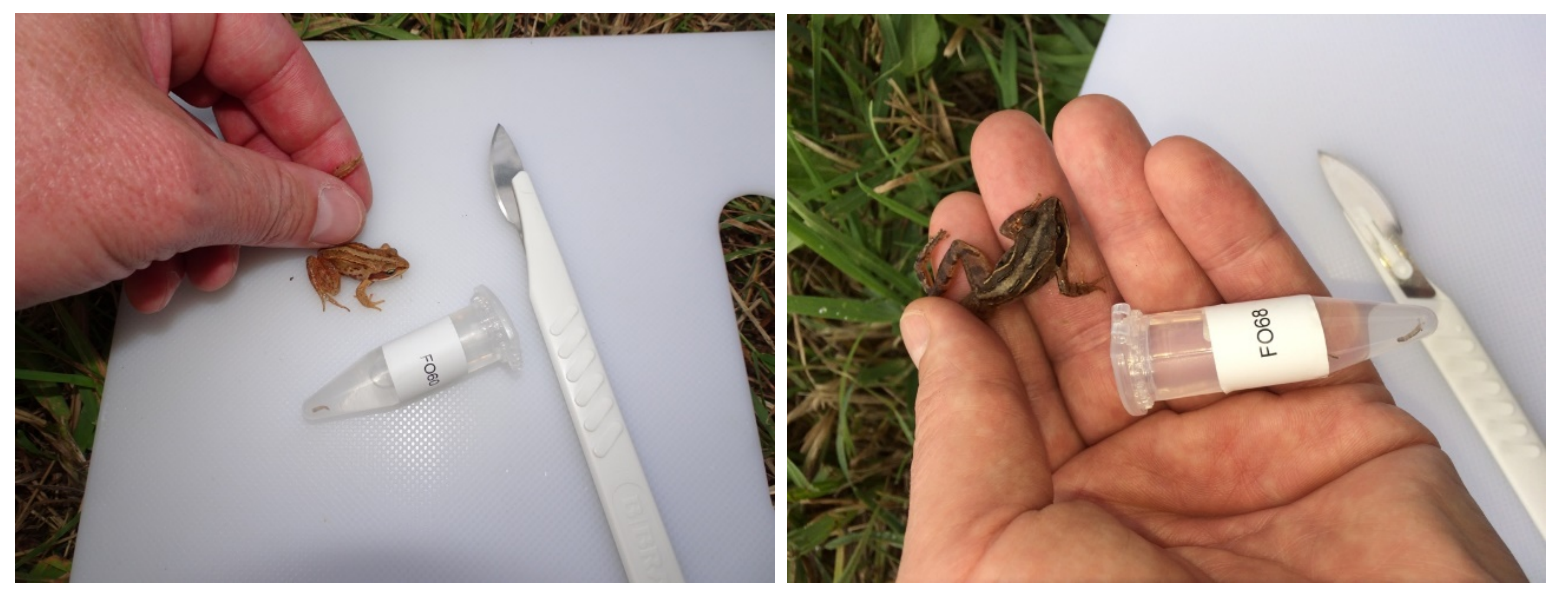

Figuur 18 Verzamelen van heikikker DNA via het knippen van een teenkootje. (c) Foto's: Fabrice Ottburg.

Alle monsters zijn in het veld verzameld in individuele buizen gevuld met geconcentreerde $(>96 \%)$ ethanol en voorzien van een unieke monstercode. Monsterbuizen zijn bij terugkomst te Wageningen opgeslagen in de vriezer bij $-20^{\circ} \mathrm{C}$ tot aan de start van de DNA-extractie (binnen een maand na monstername).

In totaal zijn er 185 DNA-monsters van heikikkers verzameld. Tabel 3.1 geeft een overzicht van het aantal verzamelde DNA-monsters van de heikikker in het studiegebied, per deelgebied en per periode, en in de referentiegebieden. Figuur 19 geeft een ruimtelijk beeld van de vindplekken waar DNAmonsters zijn verzameld, onderscheiden naar periode van monstername. De tabel laat zien dat het aantal beschikbare monsters verschilde tussen de deelgebieden. In de resultaten, waar ook beschreven staat hoeveel monsters per deelgebied daadwerkelijk een succesvol genetisch profiel opleverden, gaan we nader in op de effecten daarvan op het berekenen van diversiteitsmaten.

Tabel 3.1 Het aantal verzamelde DNA-monsters van de heikikker in het studiegebied, per deelgebied en per periode, en in de referentiegebieden.

\begin{tabular}{|c|c|c|c|}
\hline Locatie & Vroege voorjaar ${ }^{1}$ & Nazomer ${ }^{2}$ & Totaal \\
\hline Stu-NW & 0 & 10 & 10 \\
\hline Stu-NO & 48 & 11 & 59 \\
\hline Stu-Z & 18 & 10 & 28 \\
\hline Ref-NH1 & 4 & - & 4 \\
\hline Ref-NB & 14 & - & 14 \\
\hline Ref-LIM & 13 & - & 13 \\
\hline Totaal & & & 185 \\
\hline
\end{tabular}

122 februari - 4 april 2019

226 augustus - 24 september 2019

\subsubsection{Genetisch onderzoek}

Genetische analyse van de verzamelde ei- en teenmonsters vond plaats in het Laboratorium voor Ecologische Genetica van Wageningen Environmental Research te Wageningen. Daarbij is allereerst per monster een DNA-extractie uitgevoerd met behulp van de DNeasy Blood \& Tissue Kit (Qiagen; specifiek voor dierlijke weefselcellen).

Per DNA-extract is vervolgens een zogenoemd genetisch profiel vastgesteld op basis van zeven genetische merkers: stukjes code in het DNA die variatie vertonen tussen soorten of individuen, wat ze bruikbaar maakt voor genetische analyses. Hier betreft het zeven zogenaamde 'microsatellieten': 
stukjes DNA waarvan bekend is dat ze tussen individuele dieren verschillen in lengte, doordat af en toe mutaties optreden waarbij een deel van de code wordt verdubbeld of juist verwijderd. De exacte lengte van de microsatelliet kan in het laboratorium worden uitgelezen en de verschillende waargenomen lengtes worden vervolgens als verschillende genetische varianten, ofwel allelen, beschouwd. Per microsatelliet-merker kunnen individuele heikikkers dus verschillende allelen vertonen. Door de aangetroffen allelen voor alle zeven microsatelliet-merkers achter elkaar te zetten, ontstaat een code die per individu verschilt. Dit genetische profiel kan dan als een paspoort worden gebruikt om individuen aan te herkennen. Daarnaast kan de mate waarin de profielen verschillen binnen en tussen populaties worden gebruikt om uitspraken te doen over de mate waarin uitwisseling plaatsvindt tussen populaties en de genetische vitaliteit van de populaties.

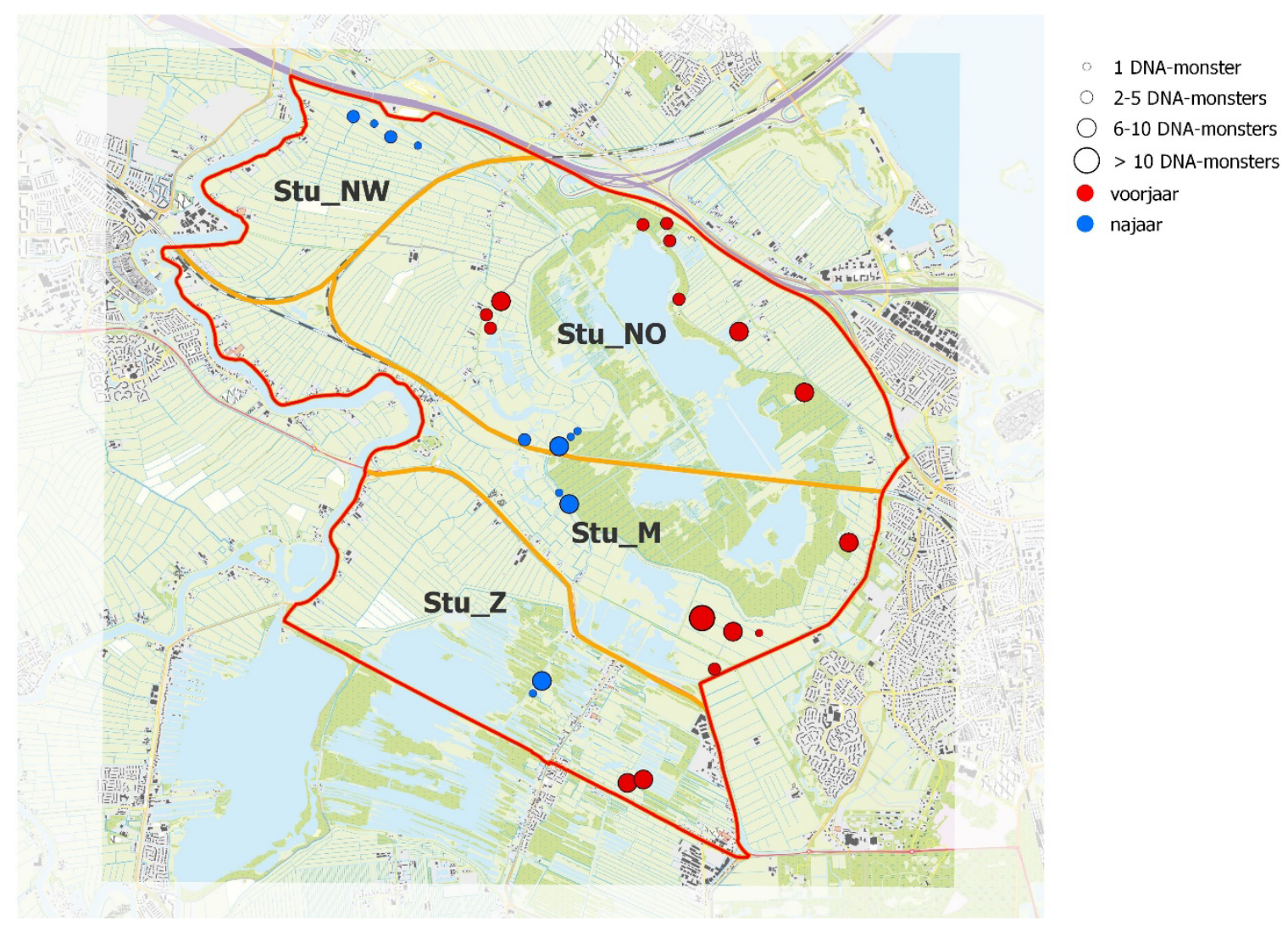

Figuur 19 De vindplekken in het studiegebied waar de DNA-monsters zijn verzameld, onderscheiden naar periode van monstername.

In de huidige studie is gebruikgemaakt van een zevental reeds eerder gepubliceerde microsatellietmerkers: RCIIDII en RECALQ (Vos et al., 2001), CA41 (Garner \& Tomio, 2002), WRA1-28 (Arens et al., 2007), WRA1-22, WRA1-160 en WRA6-8 (Knopp et al., 2007). Een achtste merker (RRD590, Vos et al., 2001) is wel getest, maar gaf onbetrouwbare resultaten - te veel en niet constant dezelfde allelen per monster - en is daarom niet opgenomen in de uiteindelijke dataset. Het protocol voor de analyse van deze set merkers is door WENR geoptimaliseerd tot een zogenoemde multiplex PCR, waarbij meerdere merkers tegelijk in dezelfde analyserun kunnen worden opgewerkt en uitgelezen (multiplex I = WRA1-22, WRA1-160, RCIIDII en CA41; multiplex II = WRA1-28, WRA6-8 en RECALQ). Het betreft daarbij losse 'primers' (zie Begrippenlijst) per merker, die echter per multiplex als één cocktail in de reactiemix worden toegevoegd. Samenstelling van deze primer-cocktails vond plaats met een gespecialiseerd computerprogramma (Multiplex Manager), zodat eventuele overlap in fragmentlengte of het op elkaar binden van primersequenties onderling (wat kan leiden tot artefacten in de resultaten) wordt voorkomen. Het uitlezen van de allelen vond plaats via een ABI 3730 DNAsequencer met 48 capillairen. 


\subsubsection{Data-analyse}

$\mathrm{Na}$ een zorgvuldige kwaliteitscheck op de verkregen genetische profielen, waarbij alle profielen zijn verwijderd die voor meer dan één merker geen geldig resultaat lieten zien, bleef een definitieve dataset over, bestaande uit 151 genetische profielen van unieke individuen. Om de genetische samenstelling van de diverse onderzochte populaties te onderzoeken en de verschillen in samenstelling tussen populaties in beeld te brengen, zijn verschillende analyses uitgevoerd op deze dataset.

Om de mate van genetische diversiteit per populatie te bepalen, is gebruikgemaakt van drie verschillende maten: (1) het totaalaantal allelen in de populatie (allelenrijkdom, $A$ ), (2) het totaalaantal allelen per populatie gecorrigeerd voor verschillen in steekproefgrootte (gecorrigeerde allelenrijkdom, $A r$ ) en (3) de verwachte heterozygositeit ( $\mathrm{He}$ ). De maten $A$ en $\mathrm{Ar}$ beschrijven het daadwerkelijke aantal genetische varianten in de populatie, inclusief varianten die heel zeldzaam zijn en daardoor gemakkelijk verloren gaan als één of enkele dieren overlijden. De maat He houdt behalve met het aantal varianten ook rekening met de relatieve verhoudingen daartussen: bij een hogere $\mathrm{He}$ waarde komen de aanwezige varianten in meer gelijke aantallen voor en is de kans kleiner dat diversiteit verloren gaat. Naast de rijkdom aan varianten in de populatie is ook gekeken naar de variatie binnen individuen op basis van de mate van aangetroffen heterozygositeit $(\mathrm{Ho})$. Dit is de gemiddelde mate waarin de twee versies die een individu van elk gen bezit (één afkomstig van de vader en één afkomstig van de moeder) van elkaar verschillen. De mate van aangetroffen heterozygositeit geeft een indicatie voor de mate van inteelt, aangezien bij paring tussen sterk verwante dieren de kans groter is dat een nakomeling van beide ouders dezelfde genetische varianten ontvangt. Hoe lager de waarde voor $\mathrm{Ho}$, hoe groter de kans op schadelijke effecten door inteelt. Voor een gedetailleerde beschrijving van deze variatie-maten en de achterliggende mechanismen, zie De Groot et al. (2014). De waarden voor $A, A r$, He en Ho zijn bepaald via het computerprogramma FSTAT (Goudet, 1995).

Om te bepalen in hoeverre de diverse populaties onderling verschillen in genetische samenstelling, is de mate van paarsgewijze genetische differentiatie $\left(F_{s t}\right)$ tussen elke combinatie van twee populaties berekend. $F_{s t}$ varieert tussen 0 en 1 . Een $F_{s t}$ van 0 geeft aan dat de genetische samenstelling van de twee populaties identiek is. Bij een $F_{s t}$ van 1 zijn de populaties maximaal verschillend, oftewel is er geen overlap in aanwezige allelen. Hartl \& Clark (1997) hanteren de volgende vuistregels voor interpretatie van $F_{s t}$-waarden: $F_{s t}$ van 0-0,05 geringe differentiatie; 0,05-0,15 redelijke differentiatie; $0,15-0,25$ grote differentiatie en $>0,25$ zeer grote differentiatie.

Om te bepalen of binnen de Vechtstreek sprake is van een zogenaamde 'isolatie door afstand'-relatie, waarbij heikikkers uit (deel)populaties die op relatief grotere afstand van elkaar gelegen zijn genetisch sterker van elkaar verschillen dan populaties op kleinere afstand, is gebruikgemaakt van een zogenaamde Mantel-correlatietest (Sokal, 1979). Daarbij is de correlatie berekend tussen een matrix van paarsgewijze geografische afstanden tussen de bezochte monsterpunten (Figuur 12) en een matrix van paarsgewijze genetische afstanden (op basis van $F_{s t}$-waarden) tussen dezelfde set monsterpunten. Deze analyse is zowel uitgevoerd voor de gehele dataset van monsters uit de Vechtstreek (exclusief Ref-NB en Ref-LIM, maar inclusief Ref-NH1 en Ref-NH2) als voor alleen de monsters van de vier deelpopulaties in het studiegebied.

Een andere manier om de verschillen tussen populaties in beeld te brengen, is door middel van Bayesiaanse clusteringstechnieken. Binnen dit onderzoek is hiervoor gebruikgemaakt van het programma STRUCTURE (Pritchard et al., 2000). STRUCTURE richt zich in eerste instantie niet op de veronderstelde populatie-indeling van de onderzochte individuen. In plaats daarvan veronderstelt het programma dat sprake is van een bepaald aantal genetische clusters $(K)$ en gebruikt vervolgens de genetische profielen om individuen toe te wijzen aan deze clusters. Elk individu kan aan een of meerdere clusters worden toegewezen. Voor de exacte methode en criteria voor deze toewijzing verwijzen we naar Pritchard et al. (2000). Vervolgens sorteert de software de individuen weer volgens de vooraf opgegeven populatie-indeling en kan gemakkelijk worden nagegaan in hoeverre de indeling in genetische clusters overeenkomt met de populaties waaruit de individuen afkomstig zijn. De STRUCTURE-analyse geeft aanvullende informatie ten opzichte van de $F_{s t}$-waarde, omdat nu een 
toewijzing op individueel niveau wordt uitgevoerd in plaats van op populatieniveau. Het optimale aantal clusters $\mathrm{K}$, en dus welk model het best bruikbaar is voor verdere interpretatie van de ruimtelijke verschillen, wordt bepaald via de zogenaamde delta-K methode (Evanno et al., 2005), waarbij gekeken wordt naar de mate waarin het toevoegen van een extra cluster aanvullende variatie in de dataset verklaart.

\section{$3.4 \quad$ Resultaten}

\subsubsection{Genetische variatie}

De aangetroffen mate van genetische variatie verschilde aanzienlijk tussen de diverse (deel)populaties (Tabel 3.2). In absolute zin is veruit het grootste aantal allelen aangetroffen in de deelpopulaties StuNO en Stu-M (respectievelijk $A=12,3$ en $A=11,7$ ), wat deels te verklaren is door de veel grotere monsteraantallen in deze gebieden. Wordt gecorrigeerd voor steekproefgrootte $(A r)$, dan is de variatie nog steeds hoog in de beide delen van het Naardermeer ( $A r=3,5$ en 3,6 voor respectievelijk Stu-NO en Stu-M), evenals in de Ankeveense Plassen (deelpopulatie Stu-Z, $A r=3,5$ ), maar zijn de verschillen tussen populaties kleiner. De laagste variatie is aangetroffen in referentiepopulatie Ref-NB. De waarden voor de verwachte heterozygositeit $\mathrm{He}$ laten relatief geringe verschillen zien, maar deze zijn in lijn met de resultaten voor $A$ en $A r$.

De daadwerkelijk aangetroffen heterozygositeit $\mathrm{Ho}$ was het laagste in de referentiepopulaties Ref-NB en Ref-LIM (Tabel 3.2). Binnen het studiegebied was deze waarde ook relatief laag in deelpopulatie Stu-NO, en juist relatief hoog in deelpopulatie Stu-M. Het feit dat voor deelpopulatie Stu-NO en referentiepopulatie Ref-LIM de aangetroffen heterozygositeit flink lager was dan de verwachte heterozygositeit $(\mathrm{He}>\mathrm{Ho})$, geeft aan dat sprake is van lokale substructuur, oftewel een onderverdeling in subgroepen waarvan de individuen onderling meer verwantschap vertonen dan het geval is tussen de subgroepen. Het lijkt erop dat ten noorden van de spoorlijn de uitwisseling tussen groepen heikikkers aan de westelijke en oostelijke zijde van het Naardermeer relatief beperkt is. Opvallend is dat ten zuiden van de spoorlijn (Stu-M) een dergelijke substructuur minder evident is, terwijl ook hier groepen heikikkers aan zowel de westelijke als oostelijke zijde van het meer zijn bemonsterd (zie Figuur 12).

Tabel 3.2 Populatie-genetische parameters voor de verschillende deelpopulaties binnen en buiten het studiegebied. $N$ = aantal individuen in de dataset (steekproefgrootte); $A=$ gemiddeld aantal allelen per merker; Ar = gemiddeld aantal allelen per merker, gecorrigeerd voor de steekproefgrootte; $\mathrm{He}=$ verwachte heterozygositeit; Ho = waargenomen heterozygositeit. Zie paragraaf 3.3.6 en de Begrippenlijst voor een beschrijving van de betekenis van deze parameters.

\begin{tabular}{|c|c|c|c|c|c|}
\hline Locatie & $N$ & $A$ & Ar & $\mathrm{He}$ & Ho \\
\hline \multicolumn{6}{|c|}{ Studiegebied } \\
\hline Stu-NW & 10 & 6,0 & 3,4 & 0,68 & 0,67 \\
\hline Stu-M & 37 & 11,7 & 3,6 & 0,72 & 0,67 \\
\hline Stu-Z & 23 & 9,6 & 3,5 & 0,71 & 0,62 \\
\hline Ref-NH1 & 3 & $*$ & $*$ & $*$ & $*$ \\
\hline Ref-NH2 & 6 & $*$ & $*$ & $*$ & $*$ \\
\hline Ref-NB & 9 & 5,7 & 3,1 & 0,60 & 0,56 \\
\hline Ref-LIM & 12 & 6,1 & 3,3 & 0,72 & 0,54 \\
\hline
\end{tabular}

* Aantal monsters te laag voor betrouwbare schatting.

\subsubsection{Genetische verschillen tussen (deel)populaties}

De genetische differentiatie tussen de diverse (deel)populaties is gering (Tabel 3.3.). Deze differentiatie is gemeten via de parameter $F_{\text {st }}$, die een waarde kan aannemen tussen 0 en 1 . Het 
kleinste genetische verschil is waargenomen tussen de deelpopulatie Stu-M en referentiepopulatie Ref$\mathrm{NH1}$. Gezien het lage aantal monsters dat in Ref-NH1 is verzameld, moet deze bevinding vooral als eerste indicatie worden gezien. Ook het verschil tussen de deelpopulaties Stu-NO en Stu-M was gering, evenals de verschillen tussen deze twee deelpopulaties in het Naardermeer en de deelpopulatie in de Ankeveense Plassen.

Een iets duidelijker verschil is gevonden tussen enerzijds de deelpopulaties Stu-NO en Stu-M en anderzijds - in volgorde van oplopende verschillen - deelpopulatie NW, referentiepopulatie Ref-NH2, Ref-LIM en Ref-NB. De paarsgewijze $F_{s t}$-waarden liggen in dezelfde range als de waarden die op vergelijkbaar geografisch schaalniveau door Knopp et al. (2007) zijn aangetroffen tussen populaties in Noord-Europa $(0,06-0,15)$ en door Rafinski \& Babik $(2000)$ in Oost-Europa $(0,08-0,12)$.

Op basis van Mantel-correlatietests is een significante 'isolatie door afstand'-relatie aangetoond voor zowel de Vechtstreek-dataset $(r=0,41 ; p=0,005)$, i.e. alle datasets exclusief die van Ref-LIM en Ref$\mathrm{NB}$, als de Vechtstreek-dataset exclusief de referentiepopulaties Ref-NH1 en Ref-NH2 ( $r=0,34$; $p=0,014)$. Dit betekent dat binnen de geografische schaal van deze dataset (minimaal $480 \mathrm{~m}$ tot maximaal $6,8 \mathrm{~km}$ afstand tussen monsterpunten) de mate van onderlinge uitwisseling aantoonbaar afnam, waarbij groepen heikikkers op grotere afstand van elkaar minder uitwisseling vertonen. Dit sluit aan bij de resultaten die circa 20 jaar geleden door Arens et al. (2007) werden gevonden voor heikikkerpopulaties in regio's van vergelijkbare omvang in Drenthe en Noord-Brabant.

Tabel 3.3 Paarsgewijze genetische differentiatie, gemeten via $F_{\text {st, }}$ tussen alle (deel)populaties. Een waarde tussen 0 en 0,05 = geringe differentiatie; tussen 0,05 tot 0,15= redelijke differentiatie; tussen 0,15 tot 0,25 = grote differentiatie; >0,25 = zeer grote differentiatie.

\begin{tabular}{llllllll} 
& Stu-NW & Stu-NO & Stu-M & Stu-Z & Ref-NH1 & Ref-NH2 & Ref-NB \\
Stu-NW & \multicolumn{7}{c}{ Ref-LIM } \\
\hline Stu-NO & 0,028 & & & & & \\
\hline Stu-M & 0,054 & 0,013 & & & & & \\
\hline Stu-Z & 0,023 & 0,019 & 0,014 & & & & \\
\hline Ref-NH1 & 0,089 & 0,019 & 0,000 & 0,030 & & & \\
\hline Ref-NH2 & 0,049 & 0,055 & 0,060 & 0,030 & 0,053 & & \\
\hline Ref-NB & 0,108 & 0,071 & 0,088 & 0,086 & 0,145 & 0,144 & \\
\hline Ref-LIM & 0,075 & 0,069 & 0,057 & 0,040 & 0,061 & 0,056 & 0,054 \\
\hline
\end{tabular}

De resultaten van de clusteranalyse bevestigen op hoofdlijnen de verschillen aangetroffen op basis van $F_{s t}$-waarden. Figuur 20 laat in grafische vorm zien op welke wijze de individuen aan verschillende genetische clusters worden toegewezen. Het aantal genetische clusters (K) wordt bij de analyse vooraf ingesteld. Wanneer de software wordt gevraagd twee clusters te formeren $(K=2)$, maakt de analyse een onderscheid tussen de verder weg gelegen referentiepopulaties Ref-NB en Ref-LIM en de populaties in de Vechtstreek. Deze twee populaties wijken dus het sterkst af in genetische samenstelling. Wordt een cluster toegevoegd $(K=3)$, dan vormen de deelpopulaties in het Naardermeer (Stu-NO en Stu-M) en referentiepopulatie Ref-NH1 een apart cluster.

Het model met vier clusters $(K=4)$ verklaart de variatie in de dataset het best - modellering met vijf clusters $(K=5)$ leverde weinig extra inzicht op in verschillen tussen individuen. Dit model is dus het bruikbaarst voor een nadere inspectie van de ruimtelijke patronen. In Figuur 20 is zichtbaar dat in dit model deelpopulatie Stu-NW - afgescheiden van deelpopulatie Stu-NO door de spoorlijn WeespAlmere - is toegewezen aan een apart genetisch cluster. Opvallend is verder dat de deelpopulaties Stu-NO en Stu-M beide zijn toegewezen aan hetzelfde (rode) cluster. Kortom, er is aan weerszijden van de spoorlijn door het Naardermeer geen sprake van een duidelijk onderscheid in verschillende genetische groepen. Wel zijn individuen uit deelpopulatie Stu-M, dus uit het gebied tussen de spoorlijn door het Naardermeer en de N236, voor een beperkt percentage toegewezen aan het (blauwe) cluster dat kenmerkend is voor de deelpopulatie Stu-Z, terwijl dit nauwelijks het geval is voor de individuen in deelpopulatie Stu-NO. Dit is een indicatie dat een deel van de genetische kenmerken van de populatie in de Ankeveense Plassen gedeeld wordt met de individuen in de Hilversumse Bovenmeent, terwijl 
deze kenmerken minder worden doorgegeven aan de deelpopulatie ten noorden van de spoorlijn. Er is dus wel een zeker verschil tussen de beide delen van het Naardermeer, maar dit verschil is zeer klein. Dit komt overeen met de resultaten voor $F_{s t}$ : genetische differentiatie tussen het noordelijke en zuidelijke deelgebied is gering, maar niet gelijk aan nul.

De populatie in de Gemeenschapspolder-Bloemendalerpolder (Ref-NH2) vormt geen eigen cluster, maar wordt gekenmerkt door een gemixte toewijzing aan meerdere clusters, die we in de andere populaties niet waarnemen. Dit is te verklaren doordat de variatie in deze populatie beperkt is tot een aantal allelen die ook in diverse andere populaties algemeen zijn. Het aantal bemonsterde individuen uit deze populatie is echter te gering om na te gaan of het ontbreken van zeldzamere allelen veroorzaakt is door genetische erosie of dat deze simpelweg gemist zijn doordat de steekproefgrootte onvoldoende was.

Twee individuen uit de Vechtstreek - een in de Gemeenschapspolder-Bloemendalerpolder (ID=1) en een in de Hilversumse Bovenmeent (ID=101) - kennen een toewijzing (aan het cluster) die afwijkend is voor individuen uit deze monsterlocaties. Dit moet vooral geïnterpreteerd worden als een aanwijzing dat deze individuen genetisch sterk afwijken van de andere individuen in deze (deel)populaties en dat dus mogelijk sprake is van immigranten uit een andere, niet bemonsterde populatie. Dat deze twee individuen aan het gele cluster werden toegekend, komt hoogstwaarschijnlijk omdat het clusteringsmodel redelijk conservatief is en niet snel geneigd is een enkel afwijkend individu een geheel eigen cluster toe te kennen. Het model kiest dan voor het meest gelijkende reeds bestaande cluster. Een daadwerkelijke herkomst uit de 'gele' populaties Ref-NB of Ref-LIM is onwaarschijnlijk.

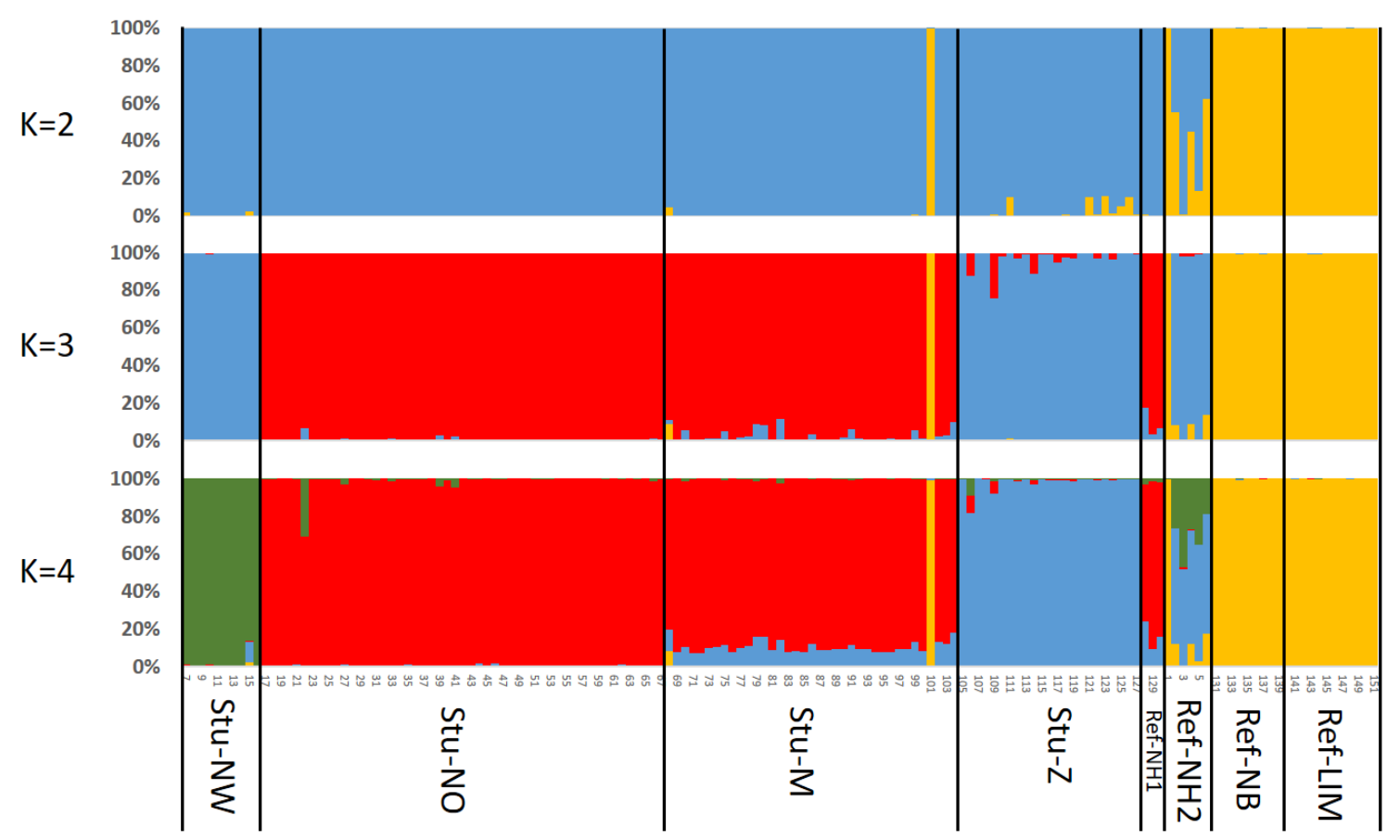

Figuur 20 Resultaten van clusteringsmodellen in het programma STRUCTURE voor drie verschillende waarden van $K$ (aantal te vormen genetische clusters). Elk van de door het programma herkende genetische cluster kent zijn eigen kleur. Elk individu is weergegeven als een smalle verticale balk die met een of meerdere kleuren is ingekleurd, afhankelijk van de verhouding waarin het individu door het programma is toegewezen aan een of meer verschillende clusters.

Figuur 21 geeft op kaart weer hoe de clustertoewijzingen per individu ruimtelijk verdeeld zijn binnen het studiegebied en in de twee nabijgelegen referentiegebieden (Gijzenveen en GemeenschapspolderBloemendalerpolder). Dit verschaft enig inzicht in de barrièrewerking van de diverse grootschalige infrastructuur in het gebied voor de heikikker. 


\section{Barrièrewerking van de provinciale weg N236}

De toewijzing van de individuen in de Ankeveense Plassen aan een apart cluster, ook ten opzichte van het relatief nabijgelegen deelgebied in het zuidelijke deel van het Naardermeergebied (Hilversumse Bovenmeent), doet vermoeden dat hier sprake is van een barrièrewerking, veroorzaakt door de tussengelegen provinciale weg. De in 2013 gerealiseerde faunapassages faciliteren naar verwachting de uitwisseling van heikikkers - hoewel dit nog niet middels een veldstudie is bevestigd -, maar deze mogelijkheid voor uitwisseling bestaat blijkbaar nog te kort en/of is nog niet van voldoende omvang om de genetische verschillen weg te nemen. Een andere factor die hier een rol zou kunnen spelen, is de eventuele barrièrewerking van de 's-Gravelandse Vaart. Heikikkers doorkruisen namelijk zelden brede wateren. Het genetische verschil tussen de deelpopulaties van het Naardermeer en die in de Ankeveense Plassen maakt het mogelijk om bij een toekomstige effectmeting een effect van de gerealiseerde faunapassages in de provinciale weg waar te nemen.

\section{Barrièrewerking van de spoorlijn door het Naardermeer}

Alle individuen bemonsterd in het Naardermeer - zowel in deelgebied Stu-NO als Stu-M - zijn toegewezen aan hetzelfde cluster, wat aangeeft dat de invloed van de spoorlijn niet heeft geresulteerd in een duidelijk genetisch onderscheid. Gezien de lange tijd die is verstreken sinds de aanleg van de spoorlijn - deze is in 1874 in gebruik genomen - duidt dit naar verwachting op bestaande uitwisseling van heikikkers tussen de deelpopulaties aan weerszijden van de spoorlijn. De drie bestaande onderdoorgangen - de brug over de Karnemelksloot, de brug midden in het reservaat over de Boomtocht/Martelaarsgracht en de brug nabij de Keverdijk - spelen hier mogelijk een rol bij. Het is daarnaast ook niet ondenkbaar dat heikikkers in sommige gevallen het ballastbed weten te doorkruisen. De spoordijk is, naast de kaden, een van de weinige plekken in het gebied die in de winter droog is, wat de dieren in relatief grote aantallen kan aantrekken naar de spoordijk voor overwintering.

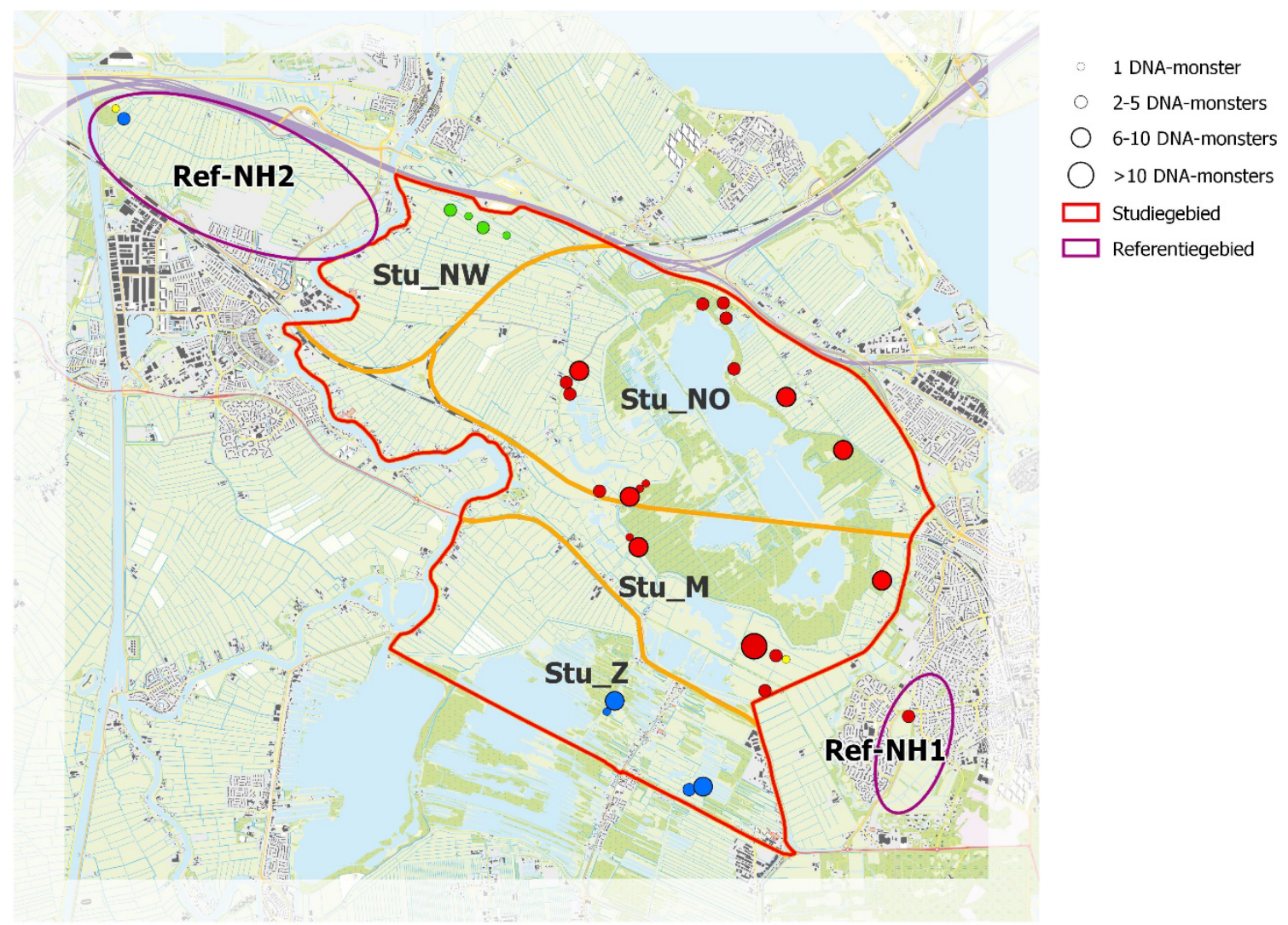

Figuur 21 Ruimtelijke weergave van de genetische patronen in het studiegebied en de twee nabijgelegen referentiegebieden. Per individu (stip) is met een kleur aangegeven aan welk genetisch cluster deze het sterkst is toegewezen. De kleuren van de genetische clusters corresponderen met Figuur 20. 
Barrièrewerking van de spoorlijn Weesp-Almere

Deze spoorlijn - de zogenoemde 'Flevolijn' - is veel jonger dan de spoorlijn door het Naardermeer. De spoorlijn is in 1987 in gebruik genomen. In 2003 is de 'Gooiboog' toegevoegd, die direct treinverkeer vanuit Flevoland in de richting van Hilversum mogelijk maakte. De toewijzing van deelpopulatie StuNW, aan de westzijde van de spoorlijn Weesp-Almere, aan een ander genetische cluster kan worden veroorzaakt door de tussengelegen spoorlijn. Het kan echter ook (mede) worden veroorzaakt door de afstand - circa 1,5 km - tussen deze deelpopulatie en de deelpopulatie Stu-NO. Deze hypothese wordt ondersteund door het feit dat binnen de dataset voor de Vechtstreek (dus exclusief de referentiepopulaties Ref-NB en Ref-LIM) een significante 'isolatie door afstand'-relatie werd aangetoond, wat aangeeft dat deelpopulaties op grotere afstand van elkaar gemiddeld minder genetische verwantschap vertonen. Een potentiële verbinding tussen de deelpopulaties wordt gevormd door het uitwateringskanaal van het Naardermeer. Deze passeert de spoorlijn via een ecoduiker. Deze natte onderdoorgang is circa dertig jaar geleden al aangepast tot een faunapassage, waarbij aan weerszijden een looprichel is geïnstalleerd. Het was de eerste faunapassage van dat type in Nederland. Vooralsnog lijkt hiermee voor de heikikker echter onvoldoende uitwisseling te zijn gefaciliteerd.

\subsection{Conclusies}

- Hoewel de genetische verschillen beperkt zijn, is er binnen het studiegebied sprake van een genetische structuur, waarbij zowel de deelpopulatie ten westen van de spoorlijn Weesp-Almere als die in de Ankeveense Plassen verschilt van de deelpopulaties in het Naardermeer.

- Het genetische verschil tussen de deelpopulaties in het Naardermeer en die in de Ankeveense Plassen maakt het naar verwachting mogelijk om bij een toekomstige effectmeting een effect van de twee in 2013 gerealiseerde faunapassages in de provinciale weg te meten.

- Het geringe genetische verschil tussen de twee deelpopulaties in het Naardermeer - respectievelijk ten noorden en zuiden van de spoorlijn - maakt het lastig om bij een toekomstige effectmeting een effect van eventuele verbeterde uitwisseling via de nieuwe faunapassages in de spoorlijn waar te nemen. Weliswaar is een $F_{s t}$-waarde gevonden tussen de twee deelpopulaties van 0,013, maar deze waarde is dusdanig laag dat een eventuele verdere afname lastig te meten zal zijn.

- Het genetische verschil tussen de deelpopulatie ten westen van de spoorlijn Weesp-Almere en de deelpopulaties in het Naardermeer maakt het naar verwachting mogelijk om bij een toekomstige effectmeting een effect van eventuele verbeteringen aan de bestaande ecoduiker in deze spoorlijn en/of de habitat rond het uitwateringskanaal, gericht op het verbeteren van de uitwisselingsmogelijkheden, te meten. 


\section{$4 \quad$ Advies effectstudie heikikker}

\subsection{Inleiding}

In dit hoofdstuk presenteren we een advies voor een effectmeting, waarmee - indien haalbaar geacht - het functioneren van de aangelegde faunapassages in de N236, de spoorlijn door het Naardermeer en de spoorlijn Weesp-Almere voor de heikikker kan worden geëvalueerd. We richten ons hierbij op de vraag hoe in de toekomst vastgesteld kan worden of er vermenging van genetische eigenschappen van de deelpopulaties heeft plaatsgevonden ten gevolge van de aanleg van de faunavoorzieningen en welk meetplan hiervoor nodig is.

\subsection{Haalbaarheid effectstudie faunapassages}

In het voorgaande hoofdstuk is geconcludeerd dat er nauwelijks genetische verschillen zijn tussen heikikkers ten noorden en ten zuiden van de spoorlijn door het Naardermeer. Dit maakt dat een effectstudie - dus een herhaling van het hier uitgevoerde genetisch onderzoek enkele jaren nadat de faunapassages in gebruik zijn genomen - geen optie is om het functioneren van de nieuwe faunapassages in de spoorlijn te meten. Voor deze faunapassages is hier daarom geen advies voor een dergelijke effectstudie uitgewerkt.

Het genetische verschil tussen de deelpopulaties in het Naardermeer en die in de Ankeveense Plassen maakt een dergelijke effectstudie naar verwachting wel mogelijk. De deelpopulaties zijn op dit moment genetisch nog duidelijk van elkaar te onderscheiden. Als dit verschil op termijn verdwijnt door uitwisseling via de twee gerealiseerde faunapassages in de provinciale weg, dan is dit naar verwachting goed te meten. Zoals al in het voorgaande hoofdstuk opgemerkt, zou hierbij ook de eventuele barrièrewerking van de hier gelegen brede wateren - waaronder de 's-Gravelandse Vaart moeten worden betrokken.

Datzelfde geldt, hoewel in mindere mate, voor de al langer bestaande en te optimaliseren faunapassage in de spoorlijn Weesp-Almere. Omdat hier naar verwachting niet alleen de barrièrewerking van de spoorlijn, maar ook de afstand tot de populaties in het Naardermeer een rol speelt, is hier in eerste instantie nader onderzoek gewenst naar de verspreiding van de soort direct rondom deze faunapassage en het gebruik ervan.

\subsection{Advies}

\subsubsection{Effectstudie faunapassages N236}

- Het advies is om het gebruik van beide faunapassages door heikikkers te onderzoeken door het uitleggen van een reeks kunstmatige schuilplekken die dagelijks wordt gecontroleerd. De nazomer lijkt hiervoor de beste periode, maar een dergelijke inventarisatie tijdens de voortplantingstijd is ook aan te bevelen. Op deze wijze kan worden vastgesteld of de soort de onderdoorgangen daadwerkelijk gebruikt en in welke mate dit gebeurt. Het advies is om dit in 2022 uit te voeren.

- Het advies is om, gelijktijdig met bovengenoemd onderzoek naar het gebruik van de twee faunapassages, de hier uitgevoerde genetische nulmeting aan te vullen met DNA-monsters van heikikkers die in de faunapassages worden gevangen of op korte afstand hiervan (tot circa $300 \mathrm{~m}$ ). Dit betreft dus een detaillering van het hier gepresenteerde beeld, met als doel vast te stellen of lokaal rond de faunapassages al aanwijzingen kunnen worden gevonden van genetische uitwisseling. 
- Het advies is om bij de verzameling van deze aanvullende monsters in en rondom de faunapassages niet alleen eieren te verzamelen en dieren te zoeken op zicht, maar ook kunstmatige schuilplekken uit te leggen om de vangkansen te vergroten.

- Het advies is om vijf jaar na bovengenoemde detaillering, dus in 2027, een effectmeting te doen. Hiervoor dienen DNA-monsters verzameld te worden van heikikkers die zich (1) in de faunapassages bevinden, (2) op korte afstand (<300 m) van de faunapassages worden aangetroffen en (3) op grotere afstand van de faunapassages in de Hilversumse Bovenmeent en het noordelijk deel van de Ankeveense Plassen voorkomen. De aanbeveling is om van beide deelpopulaties - noord en zuid van de provinciale weg - minimaal 50 monsters te verzamelen.

\subsubsection{Effectstudie faunapassage spoorlijn Weesp-Almere}

- Het advies is om het gebruik van de faunapassage door heikikkers te onderzoeken met behulp van valemmers die aan weerszijden van de ecoduiker, in aansluiting op de looprichels, worden geïnstalleerd. Deze valemmers worden dagelijks gecontroleerd. De nazomer lijkt hiervoor de beste periode, maar een dergelijke inventarisatie tijdens de voortplantingstijd is ook aan te bevelen. Op deze wijze kan worden vastgesteld of de soort de faunavoorzieningen in de ecoduiker gebruikt en in welke mate dit gebeurt. Het advies is om dit in 2022 uit te voeren.

- Het advies is om in 2022 het voorkomen van heikikkers langs het uitwateringskanaal van het Naardermeer in meer detail te inventariseren; zowel het traject tussen de Meerkade en de Keverdijk, tussen Keverdijk en spoorlijn als tussen spoorlijn en Vecht. Dit met als doel om vast te stellen of hier sprake is van een aaneengesloten leefgebied of niet.

- Het advies is om, gelijktijdig met deze inventarisatie, aanvullende DNA-monsters van heikikkers langs het uitwateringskanaal te verzamelen. Dit betreft dus een detaillering van het hier gepresenteerde beeld, met als doel vast te stellen waar de genetische verschillen optreden tussen de deelpopulaties in het Naardermeer en die ten westen van de spoorlijn Weesp-Almere. Hierdoor kan meer inzicht worden verkregen in welke mate het gevonden genetische verschil een gevolg is van de barrièrewerking van de spoorlijn dan wel van de afstand tussen de deelpopulaties.

- Het advies is om bij de verzameling van deze aanvullende monsters langs het uitwateringskanaal niet alleen eieren te verzamelen en dieren te zoeken op zicht, maar ook kunstmatige schuilplekken uit te leggen om de vangkansen te vergroten.

- Een effectmeting is pas zinvol als (1) is vastgesteld wat de genetische verschillen veroorzaakt - de spoorlijn, de afstand of een combinatie van deze en (2) er maatregelen zijn genomen om die oorzaak te mitigeren. Bijvoorbeeld door het optimaliseren van de ecoduiker of het inrichten van ecologische stapstenen. Pas als aan deze voorwaarden is voldaan, is het advies om een effectmeting te doen. Bij voorkeur vijf jaar na de uitvoering van de maatregelen. Hiervoor dienen dan opnieuw DNA-monsters verzameld te worden van heikikkers die zich (1) in de faunapassage en (2) langs het uitwateringskanaal aan weerszijden van de spoorlijn bevinden. De aanbeveling is om van beide deelpopulaties - oost en west van de spoorlijn - minimaal 50 monsters te verzamelen. 


\section{$5 \quad$ Advies effectstudie ringslang}

\section{$5.1 \quad$ Inleiding}

In dit hoofdstuk verkennen we de haalbaarheid van een genetische effectstudie, waarmee het functioneren van de in het studiegebied gerealiseerde faunapassages voor de ringslang kan worden geëvalueerd. Allereerst richten we ons daarbij op de vraag in hoeverre, gezien zijn verspreidingsvermogen, de ringslang een geschikte soort is om de effectiviteit van faunapassages aan te tonen middels genetisch onderzoek. En als de soort geschikt lijkt, hoe een dergelijke effectstudie er dan uit dient te zien.

Voor beantwoording van deze vragen is een beknopte literatuurscan uitgevoerd, vooral gericht op uitgevoerd populatie-genetisch onderzoek aan de soort in binnen- en buitenland en publicaties die informatie bevatten omtrent de barrièrewerking van infrastructuur voor de ringslang. De uitkomsten hiervan zijn gebruikt om de haalbaarheid van een effectstudie te beoordelen en, indien haalbaar geacht, adviezen voor de aanpak van een dergelijk onderzoek uit te werken.

\section{$5.2 \quad$ Werkwijze}

Met behulp van een concrete set zoektermen is naar relevante publicaties gezocht in de literatuurdatabases Biological Abstracts, Current Contents en Zoological Records. Hierbij zijn de zoektermen, 'grass snake' of 'natrix' gecombineerd met 'genetic(s)', 'DNA', 'genotype', 'gene flow', 'barrier' of 'fragmentation'. De referentielijsten in de op deze wijze gevonden publicaties zijn geraadpleegd om publicaties op te sporen die niet via genoemde databases zijn achterhaald. De literatuurlijst is vervolgens verder aangevuld met publicaties uit persoonlijke databases. Door deze werkwijze zijn naar verwachting de recentste onderzoeksresultaten uit binnen- en buitenland verkregen.

\subsection{Geschiktheid van ringslang als onderzoeksoort}

Onderzoek van Meister et al. (2010) voor ringslangpopulaties in verschillende kleine moerasgebieden in een Zwitserse laaglandregio met intensieve landbouw, liet zien dat genetische uitwisseling van ringslangen tussen deze populaties vooral werd beïnvloed door de tussengelegen afstand, en weinig tot niet door het landgebruik van het tussengelegen gebied. Op basis van genetische merkers werden signalen van uitwisseling opgepikt tussen populaties die tot $1 \mathrm{~km}$ uit elkaar lagen. Tussen deze populaties was geen sprake van genetische differentiatie; noch op basis van $F_{s t}$-waarden, noch op basis van clusteringsanalyse. In een tweede studie (Meister et al., 2012) met een iets groter schaalniveau - populaties op 10 tot $30 \mathrm{~km}$ afstand van elkaar - werd wel een zekere genetische differentiatie waargenomen tussen populaties, maar werden desondanks signalen van periodieke genetische uitwisseling vastgesteld tussen populaties tot op $16 \mathrm{~km}$ afstand.

Deze resultaten wijzen erop dat ringslangen relatief mobiel zijn en in principe in staat om intensief agrarisch landschap te doorkruisen en populaties in naburige habitatfragmenten te bereiken. Hoewel herhaling in andere studiegebieden ontbreekt, lijkt het op basis van deze studie ook onwaarschijnlijk dat populaties op kleine afstand van elkaar $(\sim 1 \mathrm{~km})$ grote genetische verschillen vertonen. Worden dergelijke verschillen wel gevonden, dan is blijkbaar sprake van een barrière die verder gaat dan simpelweg een onderbreking van het leefgebied. Juist dit potentieel hoge verspreidingsvermogen maakt de ringslang in beginsel een geschikte soort om de effectiviteit van faunapassages aan te tonen, aangezien het wegnemen of mitigeren van barrières relatief snel tot vermindering van een genetisch verschil zou moeten leiden. 
De vraag is echter wel of het waarschijnlijk is dat een dergelijke barrièrewerking voor ringslangen zou optreden en zo ja, bij welke typen infrastructuur deze mag worden verwacht. Het studiegebied van Meister et al. (2010, 2012) werd doorsneden door diverse kleinere wegen en een spoorlijn. Zij vonden geen genetisch verschil tussen populaties aan weerszijden van deze potentiële barrières. De publicatie bevat echter geen detailinformatie over de fysieke kenmerken van de aanwezige infrastructuur, zoals wegbreedte of het aantal sporen, noch over of de intensiteit van het weg- en treinverkeer.

In eigen land is eerder door een student bij het IBED (Universiteit van Amsterdam) onderzoek gedaan naar genetische variatie binnen en tussen populaties van ringslangen (Groenhout, 2014). De wijze waarop de gekozen populaties zijn afgebakend en het ontbreken van gegevens over de kenmerken en aantallen van de aanwezige infrastructuur binnen en tussen de gekozen populatiegrenzen, maakt het moeilijk om op basis van deze studie harde conclusies te trekken over het effect van infrastructuur op de genetische connectiviteit van ringslangpopulaties. Tussen de meeste populaties leek echter slechts sprake van een beperkt genetisch onderscheid, ondanks dat ze door een of meer snelwegen, spoorwegen en provinciale wegen van elkaar werden gescheiden. De populatie die door de meeste infrastructuur van andere populaties werd gescheiden, vertoonde echter wel een afwijkend profiel. Groenhout (2014) concludeert dan ook dat infrastructuur wel een effect kan hebben op de uitwisseling tussen ringslangpopulaties, maar alleen waar de effecten van meerdere infrastructurele barrières zich opstapelen.

In een studiegebied in Zuidwest-Frankrijk, doorsneden door een snelweg, spoorlijn en diverse kleinere wegen, vonden Remon et al. (2019) een duidelijke opdeling in verschillende genetische groepen onder individuele ringslangen die verspreid over het gebied werden bemonsterd. Wanneer de variatie in genetische verwantschap van individuele slangen werd gerelateerd aan mogelijke verklarende factoren, werd deze variatie het best verklaard door de aanwezigheid van de snelweg, waarbij individuen bemonsterd aan weerszijden van de snelweg gemiddeld iets minder verwant waren. Met de aanwezigheid van de spoorlijn en de kleinere wegen bestond juist een positief verband, waarbij individuen aan weerszijden van deze infrastructuur juist bovengemiddeld verwant leken. In geval van de kleinere autowegen verklaarden Remon et al. (2019) dit patroon via een combinatie van de aanwezigheid van geschikte foerageerhabitat (sloten) aan weerszijden van de kleinere (landbouw)wegen, wat ringslangen aantrekt, terwijl de wegen smal en weinig bereden waren en een oversteek dus relatief gemakkelijk en veilig was. Een dergelijke verklaring is niet gegeven voor de spoorlijn, maar hier zou iets soortgelijks kunnen spelen, omdat het een eensporige spoorlijn betrof met weinig treinverkeer.

Het is bekend dat verkeerswegen een obstakel kunnen vormen voor slangen (Vos \& Chardon, 1994; Andrews et al., 2015). Enerzijds omdat habitat - en dus dekking - ontbreekt, anderzijds omdat de dieren tijdens het passeren van de weg een grote kans lopen om te worden doodgereden. Een complicerende factor hierbij is dat verkeerswegen ook aantrekkingskracht hebben, omdat het asfalt door slangen als een geschikte zonplek kan worden gezien (Zuiderwijk, 1989). Ook kunnen wegbermen de dieren aantrekken (Van de Bund, 1991), bijvoorbeeld als deze op een op het zuiden gerichte helling liggen of er in de berm door ecologisch beheer meer prooien gevonden worden dan in omliggend (agrarisch) gebied.

Iets soortgelijks is bekend van spoorwegen (Van de Bund, 1991). Het baanlichaam ligt, zeker in moerasgebieden, meestal hoger dan de omgeving, wat het tot een aantrekkelijke zonplek voor ringslangen maakt. Ook worden (droge) spoorbermen en -dijken gebruikt voor overwintering (Meijer \& Timmermans, 1994). In hoeverre ringslangen in staat zijn om spoorlijnen te passeren en, als ze de oversteek maken, de kans op sterfte door passerende treinen, is vooralsnog niet empirisch onderzocht. Bergers (1997) stelde een lijst op van indicatorsoorten om de versnipperingseffecten van spoorwegen te onderzoeken. De ringslang maakte deel uit van deze lijst. Op basis van een literatuuronderzoek en interviews met experts was de inschatting dat spoorwegen voor de ringslang een zwakke barrièrewerking hebben, i.e. de dieren worden niet volledig gehinderd bij het passeren, maar dat sterfte door het treinverkeer naar verwachting relatief groot is. Graitson (2006) suggereert daarentegen dat het ballastbed voor slangen een redelijk veilige schuilplek voor predatoren of mensen kan vormen, terwijl ze een naderende trein goed voelen aankomen en daardoor wellicht tijdig een veilig heenkomen kunnen vinden. Ook Borda-de Agua et al. (2017) opperen dat slangen wellicht tot de 
groep vertebraten behoren die weinig last hebben van spoorwegen. Meetgegevens die dit bevestigen, ontbreken vooralsnog echter.

\subsection{Advies populatie-genetisch onderzoek ringslang}

De ringslang is in potentie dus een geschikte soort voor een effectstudie gebaseerd op een vergelijking van de situatie vóór en na opening van faunapassages, maar dit is slechts zinvol als blijkt dat in het voorstadium inderdaad sprake is van een genetisch verschil aan weerszijden van de infrastructurele barrière. Dit pleit voor een aanpak zoals uitgevoerd voor de heikikker, waarbij wordt gestart met een nulmeting om de huidige genetische patronen van de ringslang in het studiegebied te achterhalen. Genetische merkers voor individuele herkenning (microsatellieten) zijn beschikbaar in de literatuur (Meister et al., 2009) en op basis daarvan gemakkelijk operationeel te maken voor het beoogde onderzoek. Wanneer de nulmeting een ruimtelijke populatiestructuur laat zien die gerelateerd lijkt aan de (barrièrewerking van) infrastructuur, is na enkele jaren een effectmeting zinvol.

De aanbeveling is dus om een populatie-genetische studie naar de ringslang in de Vechtstreek min of meer hetzelfde vorm te geven als de studie voor heikikker. Wel adviseren wij daarbij de volgende aanpassingen:

- Het studiegebied uitbreiden, waarbij ook de leefgebieden van de ringslang ten noorden van rijksweg A1 in de studie worden betrokken. Dit biedt de kans om ook de barrièrewerking van deze snelweg te onderzoeken en de functionaliteit van de hier, relatief recent, aangelegde faunapassages. Dit betekent dat er twee deelgebieden bijkomen: het gebied ten noorden van de A1 en oosten van de A6 en het gebied ten noorden van de A1 en westen van de A6. Hierbij is extra aandacht vereist voor die locaties waar watergangen de snelweg passeren.

- Binnen deze zes deelgebieden minimaal 25 DNA-monsters van ringslangen verzamelen tijdens de nulmeting. Daarnaast is het verzamelen van minimaal 10 DNA-monsters in minimaal drie referentiegebieden van belang. Dit maakt het mogelijk de lokale genetische variatie te relateren aan de variatie binnen en ten opzichte van andere populaties in het land. Deze referentiegebieden verschillen bij voorkeur wat betreft afstand tot het studiegebied. Daarnaast is de aanbeveling om data van buitenlandse studies aan dezelfde soort te gebruiken als referentie, zoals die van Meister et al. $(2010,2012)$.

- Bij het verzamelen van de DNA-monsters tijdens de nulmeting ervoor zorgen dat per deelgebied minimaal 5 van de monsters op korte afstand van de gerealiseerde faunapassages, of zelfs daarin, worden verzameld. Hierdoor kan een gedetailleerd beeld worden gevormd van de (lokale) verschillen ter plaatse van de infrastructuur en mitigerende maatregelen.

- Bij het verzamelen van DNA-monsters vier methoden gebruiken: (1) vangen van (sub)adulte dieren op zicht, bijvoorbeeld op het moment dat de dieren uit hun winterslaap komen en zonnige plekken opzoeken, (2) vangen van dieren met behulp van uitgelegde kunstmatige schuilplekken, (3) verzamelen van eischalen in voor dit doel strategisch gesitueerde broeihopen en (4) verzamelen van vervellingshuiden en dode dieren.

- In aanvulling op de voor de heikikker gebruikte analyses, voor de ringslang ook kijken naar verwantschappen van individuele dieren. Ringslangen hebben een sterk diffuse verspreiding in het landschap. Bij een genetische studie voor de ringslang betekent dit dat genetische effecten op landschapsschaal het best kunnen worden gedaan op basis van verschillen in verwantschap tussen individuele dieren, zoals gedaan door Remon et al. (2019), en het berekenen van gradiënten van verwantschap in het landschap via Bayesiaanse modellen, zoals mogelijk is via softwarepakket GENELAND (Guillot et al., 2005). Voor heikikkers, die meer gegroepeerd voorkomen in het landschap, was die benadering minder geschikt.

- Het advies is om vijf jaar na de nulmeting een effectmeting te doen, mits in de nulmeting een ruimtelijke populatiestructuur is vastgesteld waarbij populaties in de deelgebieden voldoende genetische differentiatie vertonen. 


\section{Literatuur}

Andrews, K.M., T.A. Langen \& R.P.J.H. Struijk, 2015. Reptiles: Overlooked but often at risk from roads. In: Van der Ree et al. (eds). Handbook of Road Ecology: p. 271-280. John Wiley \& Sons. Ltd., West Sussex, VK.

Arens, P., T. van der Sluis, W.P.C. Van't Westende, B. Vosman, C.C. Vos \& M.J.M. Smulders, 2007. Genetic population differentiation and connectivity among fragmented Moor frog (Rana arvalis) populations in The Netherlands. Landscape Ecology 22: 1489-1500.

Babik, W., W. Branicki, M. Sandera, S. Litvinchuk, L.J. Borkin, J.T. Irwin \& J. Rafiński, 2004. Mitochondrial phylogeography of the Moor frog, Rana arvalis. Molecular Ecology 13: 1469-1480. doi: 10.1111/j.1365-294X.2004.02157.x.

Bergers, P.J.M., 1997. Versnippering door railinfrastructuur - Een verkennende studie. IBN-rapport 262. Instituut voor Bos- en Natuuronderzoek, Wageningen.

Borda-de Agua, L., R. Barrientos, P. Beja \& H.M. Pereira (eds.), 2017. Railway Ecology. Springer International Publishing, Cham, Zwitserland. doi: 10.1007/978-3-319-57496-7.

de Groot, G.A., H.A.H. Jansman, J. Bovenschen, I. Laros, Y. Meyer-Lucht \& J. Hoglund, 2014. Inteelt onder Sallandse korhoenders: de genetische gevolgen van een kleine populatieomvang. Rapport 2599. Alterra, Wageningen.

Evanno, G., S. Regnaut \& J. Goudet, 2005. Detecting the number of clusters of individuals using the software STRUCTURE: a simulation study. Molecular Ecology 14: 2611-2620.

Frankham, R., 1997. Do island populations have less genetic variation than mainland populations? Journal of Heredity 78: 311-327.

Frankham, R. 1998. Inbreeding and extinctions: island populations. Conservation Biology 12: 665675.

Garner, T.W.J. \& G. Tomio, 2002. Microsatellites for use in studies of the Italian agile frog, Rana latastei (Boulenger). Conservation Genetics 2: 77-80.

Goudet, J., 1995. FSTAT (version 1.2): A computer program to calculate F-statistics. Journal of Heredity 86: 485-486.

Goverse, E. \& R. Creemers, 2018. Nulmeting heikikker (en ringslang) in de regio Naardermeer. Actualisatie voorkomen heikikker (en ringslang) in het Naardermeer, Overscheense Polder, Nieuwe Keverdijkse Polder, Heintjesrak- en Broekerpolder en Ondermeent. Rapport 2018.105. Stichting RAVON, Nijmegen.

Goverse, E., R. Slagboom \& A. van der Lugt, 2014. Heikikkers inventariseren in het veenweidegebied. Schubben \& Slijm 19: 6-9.

Graitson, E., 2006. Répartition et ecologie des reptiles sur le réseau ferroviaire en Wallonie. Bulletin de la Société Herpétologique de France 120: 15-32.

Groenhout, E., 2014. Population structure of the grass snake (Natrix natrix) in the Netherlands analyzed using microsatellite data. Msc thesis. IBED, Universiteit van Amsterdam, Amsterdam.

Guillot, G., F. Mortier \& A. Estoup, 2005. Geneland: A program for landscape genetics. Molecular Ecology Notes 5: 712-715.

Hartl, D.L. \& A.G. Clark, 1997. Principles of population genetics. Sinauer Associates, Inc., Sunderland, VS.

Hels, T. \& E. Buchwald, 2001. The effect of road kills on amphibian populations. Biological Conservation 99: 331-340.

Herder, J.E. (red.), 2010. Atlas van de Noord-Hollandse amfibieën en reptielen. Landschap NoordHolland, Heiloo \& Stichting RAVON, Nijmegen.

Knopp, T., J.M. Cano, P-A. Crochet \& J. Merilä, 2007. Contrasting levels of variation in neutral and quantitative genetic loci on island populations of Moor frogs (Rana arvalis). Conservation Genetics 8: 45-56.

Knopp, T. \& J. Merilä, 2009a. The postglacial recolonization of Northern Europe by Rana arvalis as revealed by microsatellite and mitochondrial DNA analyses. Journal of Heredity 102: 174-181.

Knopp, T. \& J. Merilä, 2009b. Microsatellite variation and population structure of the Moor frog (Rana arvalis) in Scandinavia. Molecular Ecology 18: 2996-3005.

Meijer, J.P.H. \& G. Timmermans, 1994. Spoorlijnen, landschap en landschapsarchitectuur. Groen 50(12): 30-31. 
Meister, B., G.F.J. Armbruster, N. Frauenfelder \& B. Baur, 2009. Novel microsatellite loci in the grass snake (Natrix natrix) and cross-amplification in the dice snake (Natrix tessellata). Molecular Ecology 9: 604-606.

Meister, B., H. Hofer, S. Ursenbacher \& B. Baur, 2010. Spatial genetic analysis of the grass snake, Natrix natrix (Squamata: Colubridae), in an intensively used agricultural landscape. Biological Journal of the Linnean Society 101: 51-58.

Meister, B., S. Ursenbacher \& B. Baur, 2012. Grass snake population differentiation over different geographical scales. Herpetologica 68: 134-145.

Movares, 2009. Ontsnippering Spoorlijn Naardermeer. Variantenstudie. Rapport BO-LBM-080039512. Movares Nederland BV, Utrecht.

Movares, 2012. Voorlopig Ontwerp Faunapassage Naardermeer. Rapport B85-LMA-KA-1100385 Versie 1.0. Movares Nederland BV, Utrecht.

Müller, A.S., P.P. Lenhardt \& K. Theissinger, 2013. Pros and cons of external swabbing of amphibians for genetic analyses. European Journal of Wildlife Research 59: 609-612.

Oranjewoud, 1998. Variantenstudie ecologische verbinding Naardermeer-Ankeveense Plassen. Ingenieursbureau Oranjewoud, Almere.

Ottburg, F.G.W.A. \& R.J.F. Bugter, 2017. Second opinion op 'Compensatieplan Bloemendalerpolder te Weesp en Muiden'. Specifiek met het oog op beschermde heikikkers en rugstreeppadden. Rapport 2855. Wageningen Environmental Research, Wageningen.

Pontoppidan, M-B. \& G. Nachman, 2013. Spatial Amphibian Impact Assessment - a management tool for assessment of road effects on regional populations of Moor frogs (Rana arvalis). Nature Conservation 5: 29-52. doi: 10.3897/natureconservation.5.4612.

Pritchard, J.K., M. Stephens \& P. Donnelly, 2000. Inference of population structure using multilocus genotype data. Genetics 155: 945-959.

Provincie Noord-Holland, 2004. Natuurverbinding Naardermeer-Ankeveense Plassen. Interne notitie. Provincie Noord-Holland \& Dienst Landelijk Gebied, Haarlem.

Rafinski, J. \& W. Babik, 2000. Genetic differentiation among northern and southern populations of the moor frog Rana arvalis in central Europe. Journal of Heredity 84: 610-618.

Remon, J., S. Moulherat, J.H. Cornuau \& L. Gendron, 2019. Patterns of gene flow across multiple anthropogenic infrastructures: insights from a multi-species approach. Preprint. doi: 10.1101/2019.12.16.877670.

Sokal, R.R., 1979. Testing statistical significance of geographic variation patterns. Systematic Zoology 28: $227-232$.

van de Bund, C.F., 1991. Herpetofauna in weg- en spoorbermen. In: A.P.H. Stumpel \& J.J. van Gelder (red.). Natuurbeheer voor reptielen en amfibieën. Publicatie nr. 7. Werkgroep Amfibieën en Reptielen Nederland, Amsterdam.

van der Grift, E.A. \& A.F. Aartsen, 1997. Versnippering van de natuur door railinfrastructuur in de Randstad - Een studie naar knelpunten en ontsnipperingsmaatregelen in de ecologische hoofdstructuur. Holland Railconsult, Utrecht.

van der Grift, E.A., 2004. Natuurverbinding Naardermeer-Ankeveense Plassen. Advies voor inrichtingsmaatregelen rond de N236 en 's-Gravelandse Vaart. Rapport 1033. Alterra, Wageningen.

van der Grift, E.A., J. Dirksen, H. Kuijpers \& R. Wegman, 2009. Actualisatie doelen en doelsoorten Meerjarenprogramma Ontsnippering. Rapport 1941. Alterra, Wageningen.

van der Grift, E.A. \& F.G.W.A. Ottburg, 2014. Ontsnipperingsplan Naardermeer. Advies voor faunapassages bij de spoorlijn. Rapport 2521. Alterra, Wageningen.

van der Lugt, A. \& R. Slagboom, 2016. Heikikkers in het veenweidegebied. RAVON 63, 18(4): 77-79.

Veen, P.J. \& F.J. Jorna, 1994. Natuur van het zuiverste water. Deel 1: Nieuwe moerassen rond het Naardermeer. Vereniging Natuurmonumenten, 's-Graveland.

Vos, C.C. \& J.P. Chardon, 1994. Herpetofauna en verkeerswegen: een literatuurstudie. DWW-rapport W-DWW-94.730. Rijkswaterstaat, Dienst Weg- en Waterbouwkunde, Delft.

Vos, C.C. \& J.P. Chardon, 1998. Effects of habitat fragmentation and road density on the distribution pattern of the Moor frog Rana arvalis. Journal of Applied Ecology 35: 44-56.

Vos, C.C., A.G. Antonisse-De Jong, P.W. Goedhart \& M.J.M. Smulders, 2001. Genetic similarity as a measure for connectivity between fragmented Moor frog (Rana arvalis) populations. Heredity $86:$ 598-608.

Zuiderwijk, A., 1989. Reptielen in wegbermen. Een analyse van 106 locaties. Universiteit van Amsterdam, Instituut voor Taxonomische Zoölogie, Amsterdam. 


\title{
Populatie-genetische begrippenlijst
}

\author{
Isolatie door afstand \\ Een situatie waarbij (deel)populaties sterker van elkaar verschillen in genetische samenstelling \\ naarmate ze op grotere geografische afstand van elkaar liggen. Dit is een teken dat individuen niet \\ ongelimiteerd kunnen verspreiden, maar een ver weg gelegen populatie minder gemakkelijk bereiken \\ dan een dichtbij gelegen populatie. Dit patroon kan in genetische studies worden vastgesteld door \\ voor een set van populaties de correlatie te berekenen tussen twee matrices met paarsgewijze \\ waarden voor respectievelijk een maat voor de genetische differentiatie (zie onder) en een maat voor \\ geografische afstand (zoals het hemelsbrede aantal kilometers).
}

\section{Genetische differentiatie}

De mate waarin (deel)populaties onderling verschillen in genetische samenstelling.

\section{$\mathbf{F}_{\mathbf{s t}}$}

Een op basis van genetische profielen te berekenen waarde voor de mate van genetische differentiatie. $F_{s t}$ varieert tussen 0 en 1 . Een $F_{s t}$ van 0 geeft aan dat de genetische samenstelling van de twee populaties identiek is. Bij een $F_{\text {st }}$ van 1 zijn de populaties maximaal verschillend, oftewel is er geen overlap in aanwezige allelen. Hartl \& Clark (1997) hanteren de volgende vuistregels voor interpretatie van $F_{s t}$-waarden: $F_{s t}$ van 0-0,05 geringe differentiatie; 0,05-0,15 redelijke differentiatie; 0,15-0,25 grote differentiatie en $>0,25$ zeer grote differentiatie.

\section{Genetische variatie}

De diversiteit aan genetische varianten die aanwezig is in een populatie.

\section{A}

Allelenrijkdom. Een maat voor de genetische variatie in een (deel)populatie of (deel)gebied, berekend als het gemiddelde aantal genetische varianten (allelen) dat per genetische merker in de populatie is aangetroffen.

\section{Ar}

Allelenrijkdom gecorrigeerd voor de steekproefgrootte (het aantal verkregen individuele profielen per populatie).

\section{Homozygositeit}

Bij de meeste diersoorten bevat het genoom van een individu van elk gen (of elk willekeurig ander stukje van het genoom) twee exemplaren, waarvan er eentje afkomstig is van de moeder en de andere van de vader. Als beide exemplaren identiek zijn (kortom, twee keer dezelfde genetische variant of wel hetzelfde allel), spreekt men van een homozygoot. De homozygositeit op populatieniveau wordt berekend door per merker te kijken welk percentage van de individuen hier een homozygoot is, en deze percentages vervolgens te middelen over alle merkers. Een hoge homozygositeit duidt vaak op een hoog niveau van inteelt en kan voor problemen zorgen doordat schadelijke mutaties tot uiting komen die normaal gesproken door een tweede (normaal) allel worden onderdrukt.

\section{Heterozygositeit}

Het omgekeerde van de homozygositeit, kortom de mate waarin individuen in een populatie juist per stukje van het genoom twee verschillende varianten (allelen) vertonen. De heterozygositeit op populatieniveau wordt berekend door per merker te kijken welk percentage van de individuen hier een heterozygoot is en deze percentages vervolgens te middelen over alle merkers. 
Ho

De zogenaamde 'aangetroffen heterozygositeit', oftewel het daadwerkelijk gemeten gemiddelde percentage homozygotie op basis van een set van genetische merkers.

\section{He}

De zogenaamde 'verwachte heterozygositeit'. Dit betreft een theoretische schatting van de heterozygositeit die men zou verwachten in een populatie indien sprake zou zijn van willekeurige menging (kortom, elke combinatie van twee individuen heeft evenveel kans om tot nageslacht te leiden). Deze waarde wordt op twee manieren gebruikt:

- Als $\mathrm{He}$ veel hoger is dan $\mathrm{Ho}$, is dit een teken dat in werkelijkheid geen sprake is van willekeurige menging, maar dat de populatie is onderverdeeld in subgroepen die vooral onderling met elkaar paren (bijvoorbeeld doordat twee deelgroepen van elkaar gescheiden zijn door een verspreidingsbarrière).

- Daarnaast wordt He ook wel gebruikt als een extra maat voor de genetische variatie in een populatie. Het voordeel van $\mathrm{He}$ als variatie-maat is dat deze, afgezien van het absolute aantal allelen, ook afhangt van de relatieve verhoudingen daartussen: als allelen in een meer evenwichtige verhouding voorkomen, resulteert dit in een hogere He. Daarmee is deze maat minder gevoelig voor het toevallig wel of niet opduiken van een zeldzaam allel.

\section{Microsatelliet}

Een specifiek type genetische merker. Het betreft hier een fragment van het genoom waarvan bekend is dat het verschillen in lengte vertoont tussen individuen binnen een soort. Daarmee is het bruikbaar als onderdeel van een genetisch profiel om individuen mee te herkennen.

\section{Genetisch profiel}

Een unieke combinatie van genetische varianten van (meestal) meerdere merkers waaraan een individu te herkennen is.

\section{PCR}

Polymerase Chain Reaction. Een laboratoriumtechniek waarbij een natuurlijk enzym (polymerase) wordt gebruikt om een specifiek stukje van het genoom (zoals een microsatelliet of een ander type fragment dat bruikbaar is als genetische merker) te vermenigvuldigen.

\section{Primer}

Een kunstmatig stukje DNA dat aanhecht op een specifieke plek in het genoom en daar als startpunt of eindpunt dient voor de vermenigvuldiging van het DNA door een polymerase enzym. De primers die aan een PCR-reactie worden toegevoegd, zijn daarmee bepalend voor welk stukje van het genoom vermenigvuldigd wordt, en verschillen dus per genetische merker. 
Wageningen Environmental Research Postbus 47

6700 AA Wageningen

T 0317480700

www.wur.nl/environmental-research

Wageningen Environmental Research

Rapport 3115

ISSN 1566-7197
De missie van Wageningen University \& Research is 'To explore the potential of nature to improve the quality of life'. Binnen Wageningen University \& Research bundelen Wageningen University en gespecialiseerde onderzoeksinstituten van Stichting Wageningen Research hun krachten om bij te dragen aan de oplossing van belangrijke vragen in het domein van gezonde voeding en leefomgeving. Met ongeveer 30 vestigingen, 6.800 medewerkers ( $6.000 \mathrm{fte}$ ) en 12.900 studenten behoort Wageningen University \& Research wereldwijd tot de aansprekende kennisinstellingen binnen haar domein. De integrale benadering van de vraagstukken en de samenwerking tussen verschillende disciplines vormen het hart van de unieke Wageningen aanpak. 


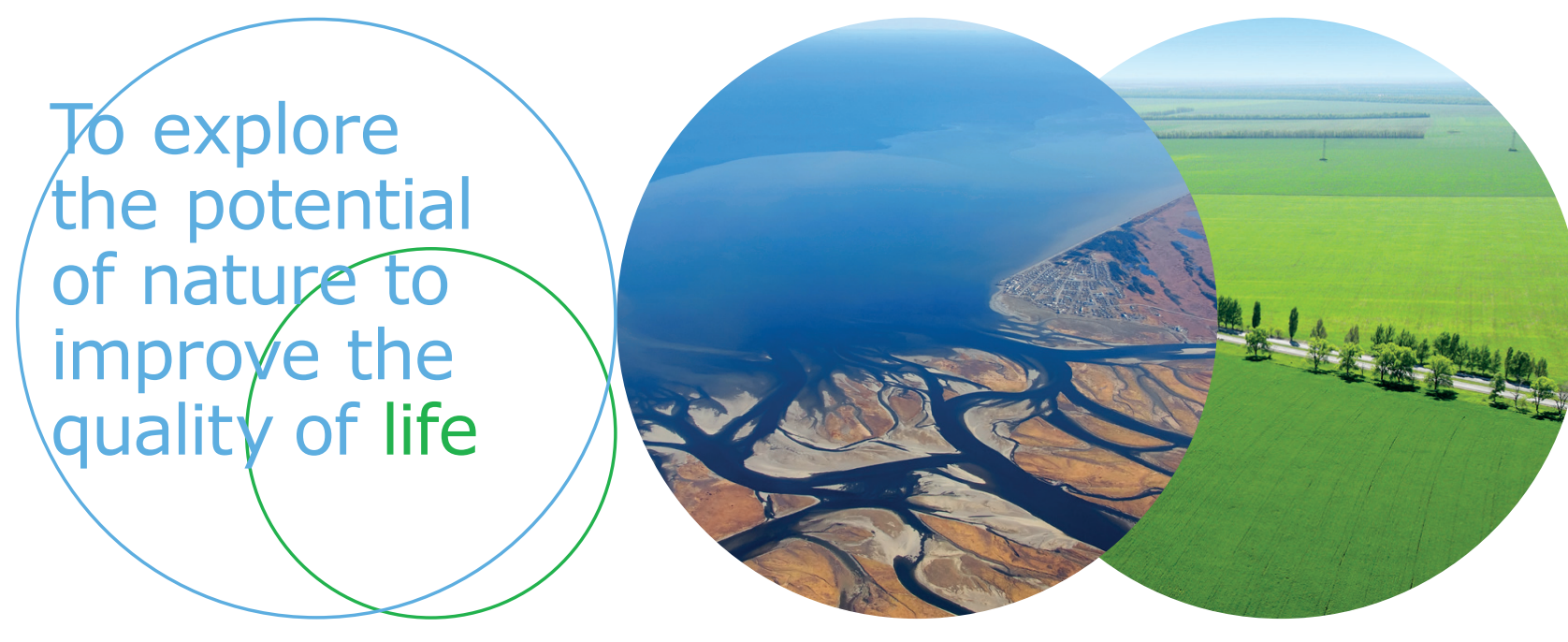

Wageningen Environmental Research Postbus 47

$6700 \mathrm{AB}$ Wageningen

T 317480700

www.wur.nl/environmental-research

Rapport 3115

ISSN 1566-7197
De missie van Wageningen University \& Research is 'To explore the potential of nature to improve the quality of life'. Binnen Wageningen University \& Research bundelen Wageningen University en gespecialiseerde onderzoeksinstituten van Stichting Wageningen Research hun krachten om bij te dragen aan de oplossing van belangrijke vragen in het domein van gezonde voeding en leefomgeving. Met ongeveer 30 vestigingen, 6.800 medewerkers (6.000 fte) en 12.900 studenten behoort Wageningen University \& Research wereldwijd tot de aansprekende kennisinstellingen binnen haar domein. De integrale benadering van de vraagstukken en de samenwerking tussen verschillende disciplines vormen het hart van de unieke Wageningen aanpak. 